\author{
Monograph \\ urn:1sid:zoobank.org:pub:DE1B1DEE-9871-4803-9F67-025F2B439560
}

\title{
Deep-sea Echinoderidae (Kinorhyncha: Cyclorhagida) from the Northwest Pacific
}

\author{
Martin V. SØRENSEN ${ }^{1, *}$, Melissa ROHAL ${ }^{2}$ \& David THISTLE ${ }^{3}$ \\ ${ }^{1}$ Section for GeoGenetics, Natural History Museum of Denmark, University of Copenhagen, \\ DK-1350 Copenhagen, Denmark. \\ ${ }^{2}$ Harte Research Institute, Texas A\&M University - Corpus Christi, Corpus Christi, TX 78412, USA. \\ ${ }^{3}$ Department of Earth, Ocean and Atmospheric Sciences, Florida State University, \\ Tallahassee, FL 32306-4520, USA. \\ *Corresponding author: mvsorensen@snm.ku.dk \\ ${ }^{2}$ Email:mrohal@islander.tamucc.edu \\ ${ }^{3}$ Email: dthistle@fsu.edu \\ ${ }^{1}$ urn:1sid:zoobank.org:author:4143D650-12FC-4914-93F5-2C39339A7156 \\ ${ }^{2}$ urn:1sid:zoobank.org:author:FE6165E7-AF07-4751-A3BE-453A48A700B6 \\ ${ }^{3}$ urn:1sid:zoobank.org:author:B388C0B0-2D25-43B2-A518-5360A45ABC72
}

\begin{abstract}
The bathyal kinorhynch fauna along the Northwest American continental rise is explored, with emphasis on species of Echinoderidae Zelinka, 1894. Seven species of Echinoderes Claparède, 1863 are described as new to science: E. anniae sp. nov., E. dubiosus sp. nov., E. hamiltonorum sp. nov., E. hviidarum sp. nov., E. juliae sp. nov., E. lupherorum sp. nov. and E. yamasakii sp. nov. Three known species, Echinoderes hakaiensis Herranz, Yangel \& Leander, 2017, E. cf. unispinosus Yamasaki, Neuhaus \& George, 2018 and Fissuroderes higginsi Neuhaus \& Blasche, 2006, are reported. The numerous new species indicate that the deep-sea still holds a great, undiscovered diversity of kinorhynchs, and that Echinoderes, as is also the case in more shallow, coastal waters, represents an important component of the deep-sea kinorhynch fauna. The presence of E. hakaiensis in the deepsea sediments demonstrates that the species may occur at a great depth range, and suggests that depth may play a less important role for the distribution of some kinorhynch species. The finding of the Northeast Atlantic species E. cf. unispinosus and the Southwest Pacific species Fissuroderes higginsi could indicate that kinorhynch species in the deep-sea may cover considerably larger distributional ranges than is assumed for coastal species of Echinoderidae.
\end{abstract}

Keywords. Echinoderes, Fissuroderes, kinorhynchs, meiofauna, new species, taxonomy.

Sørensen M.V., Rohal M. \& Thistle D. 2018. Deep-sea Echinoderidae (Kinorhyncha: Cyclorhagida) from the Northwest Pacific. European Journal of Taxonomy 456: 1-75. https://doi.org/10.5852/ejt.2018.456

\section{Introduction}

Species of the meiobenthic group Kinorhyncha Dujardin, 1851 are today known from most parts of the world, and over the last ten years, studies of their taxonomy and biogeography have intensified 
considerably (Sánchez et al. 2012, 2013; Dal Zotto et al. 2013; Herranz \& Pardos 2013; Herranz et al. 2014, 2018; Neuhaus et al. 2014; Sørensen \& Landers 2014, 2017; Neuhaus \& Kegel 2015; Dal Zotto \& Todaro 2016; Herranz \& Leander 2016; Landers \& Sørensen 2016; Neves et al. 2016; Pardos et al. 2016a, 2016b; Sánchez \& Yamasaki 2016; Sørensen et al. 2016a, 2016b; Yamasaki 2016a, 2016b; Landers et al. 2018). However, most of our knowledge about these intriguing and largely understudied animals is restricted to coastal species and species living on the continental shelfs. We have very limited information on their occurrence in the deep-sea, even though they have been found down to hadal depths. Unidentified abyssal and hadal kinorhynchs have been reported from $5411 \mathrm{~m}$ on the Hatteras Abyssal Plain in the Northwest Atlantic off the US East Coast (Tietjen et al. 1989), from $7800 \mathrm{~m}$ in the Atacama Trench (Danovaro et al. 2002), and Dr Daniel Leduc has provided unpublished photos to the first author (MVS), showing specimens of unidentified Echinoderes from $9000 \mathrm{~m}$ in the Kermadec Trench.

The first identified kinorhynchs collected below the mesopelagic zone (i.e., below $1000 \mathrm{~m}$ ) were reported by Neuhaus \& Blasche (2006) who described five species of Fissuroderes Neuhaus \& Blasche, 2006 from depths down to $3202 \mathrm{~m}$ in the Hikurangi Trough east of New Zealand. Only two years later, Sørensen (2008) described Polacanthoderes martinezi Sørensen, 2008 from $2274 \mathrm{~m}$ depth in the area between the South Shetland Islands and Antarctica. Neuhaus \& Sørensen (2013) published an account of the global distribution of the potentially cryptic species complex of Campyloderes vanhoeffeni Zelinka, 1913 which has been recorded from a very broad depth range, going from the intertidal to $5118 \mathrm{~m}$ depth. Campyloderes cf. vanhoeffeni was hence the first kinorhynch known to inhabit the abyssal zone. In addition, two new abyssal species, Cristaphyes nubilis (Sánchez, Pardos \& Sørensen, 2014) and Krakenella farinelli (Sánchez, Pardos \& Sørensen, 2014), and a new species and genus, Mixtophyes abyssalis Sánchez, Pardos \& Sørensen, 2014, were described in the following year from $5174 \mathrm{~m}$ depth in the Angola Basin (Sánchez et al. 2014a, 2014b). More recently, Adrianov \& Maiorova $(2015,2016$, in press) published a series of papers on deep-sea species from the Sea of Okhotsk and the abyssal plains near the Kuril-Kamchatka Trench. These species include an as yet unpublished new species of Meristoderes Herranz et al., 2012 from $3351 \mathrm{~m}$ depth (Adrianov \& Maiorova in press), Condyloderes kurilensis Adrianov \& Maiorova, 2016 from $5222 \mathrm{~m}$ depth, and Cristaphyes abyssorum (Adrianov \& Maiorova, 2015) from $5766 \mathrm{~m}$ depth, making the latter species the deepest identified kinorhynch known so far.

Interestingly, the otherwise very abundant and most speciose kinorhynch genus Echinoderes Claparède, 1863 was not until very recently reported from bathyal depths. In two contributions about the kinorhynch fauna of seamounts and their surrounding deep-sea plains, Yamasaki et al. (2018a, 2018b) described Echinoderes bathyalis Yamasaki, Neuhaus \& George, 2018 and Echinoderes unispinosus Yamasaki, Neuhaus \& George, 2018 from depths of 2721 to $2875 \mathrm{~m}$ at and around Sedlo Seamount near the Azores in the Northeast Atlantic. About the same time, Grzelak \& Sørensen (2018, in press) examined the kinorhynch fauna of Svalbard, and described Echinoderes drogoni Grzelak \& Sørensen, 2017 that occurs at relatively low depths in the Svalbard fjords, from $78 \mathrm{~m}$ to $310 \mathrm{~m}$ (Grzelak \& Sørensen 2018), but also down to $2128 \mathrm{~m}$ on the deep-sea plains between Svalbard and the North Pole (Grzelak \& Sørensen in press). Very recently, one additional species, Echinoderes pterus Yamasaki et al., 2018, was described. The species has a wide distribution from a position close to the North Pole, through the North Atlantic and into the Mediterranean, and is found at depths from 675 to $4403 \mathrm{~m}$ (Yamasaki et al. 2018c).

Hence, at present we only know four bathyal species of Echinoderes, and a total of eight species of bathyal Echinoderidae Zelinka, 1894. The present contribution focuses on Echinoderidae from the Northeast Pacific collected at depths between 2702 to $3853 \mathrm{~m}$ off the United States west coast, along a stretch from southern Oregon to southern California. The kinorhynch fauna of the North American west coast is generally understudied. The most intensively studied area is north-western Washington State and southern British Columbia, Canada. The San Juan Islands between Washington State and 
Vancouver Island were thoroughly explored by R.P. Higgins during the 1960's and 70's, and two species of Echinoderidae, Echinoderes pennaki Higgins, 1960 and E. kozloff Higgins, 1977, and four species of Pycnophyidae Zelinka, 1896, Higginsium cataphractus (Higgins, 1961), Pycnophyes ilyocryptus (Higgins, 1961), P. parasanjuanensis Adrianov \& Higgins, 1996 and P. sanjuanensis Higgins, 1961, were described from the islands (Higgins 1960, 1961, 1977; Adrianov \& Higgins 1996). More recently M. Herranz recollected Higgins' Echinoderes species from Calvert Island and Vancouver Island in British Columbia (Herranz \& Leander 2016; Herranz et al. 2018), and found in addition the putatively introduced Japanese species Echinoderes ohtsukai Yamasaki \& Kajihara, 2012 (see Herranz \& Leander 2016) and the new species E. hakaiensis Herranz, Yangel \& Leander, 2017 in Herranz et al. (2018). No kinorhynch records exist from Oregon, and only three species are reported from California. These include P. ilyocryptus, which was recollected in Tomales Bay north of San Francisco (Higgins 1964), the sand dwelling Cephalorhyncha nybakkeni (Higgins, 1986), which was described from a beach near Monterey (Higgins 1986), and finally the somewhat questionable record of Semnoderes pacificus Higgins, 1967, reported from Redondo Beach near Los Angeles but originally described from New Caledonia in the Southwest Pacific (Higgins 1967). The only Northeast Pacific kinorhynch record from non-coastal habitats is Antygomonas oreas Bauer-Nebelsick, 1996, which was described from a depth of $500-700 \mathrm{~m}$ at the Fieberling Seamount, about $1000 \mathrm{~km}$ off southern California (Bauer-Nebelsick 1996). Hence, the present study presents data from a geographic area and depth range for which the kinorhynch fauna is completely unexplored.

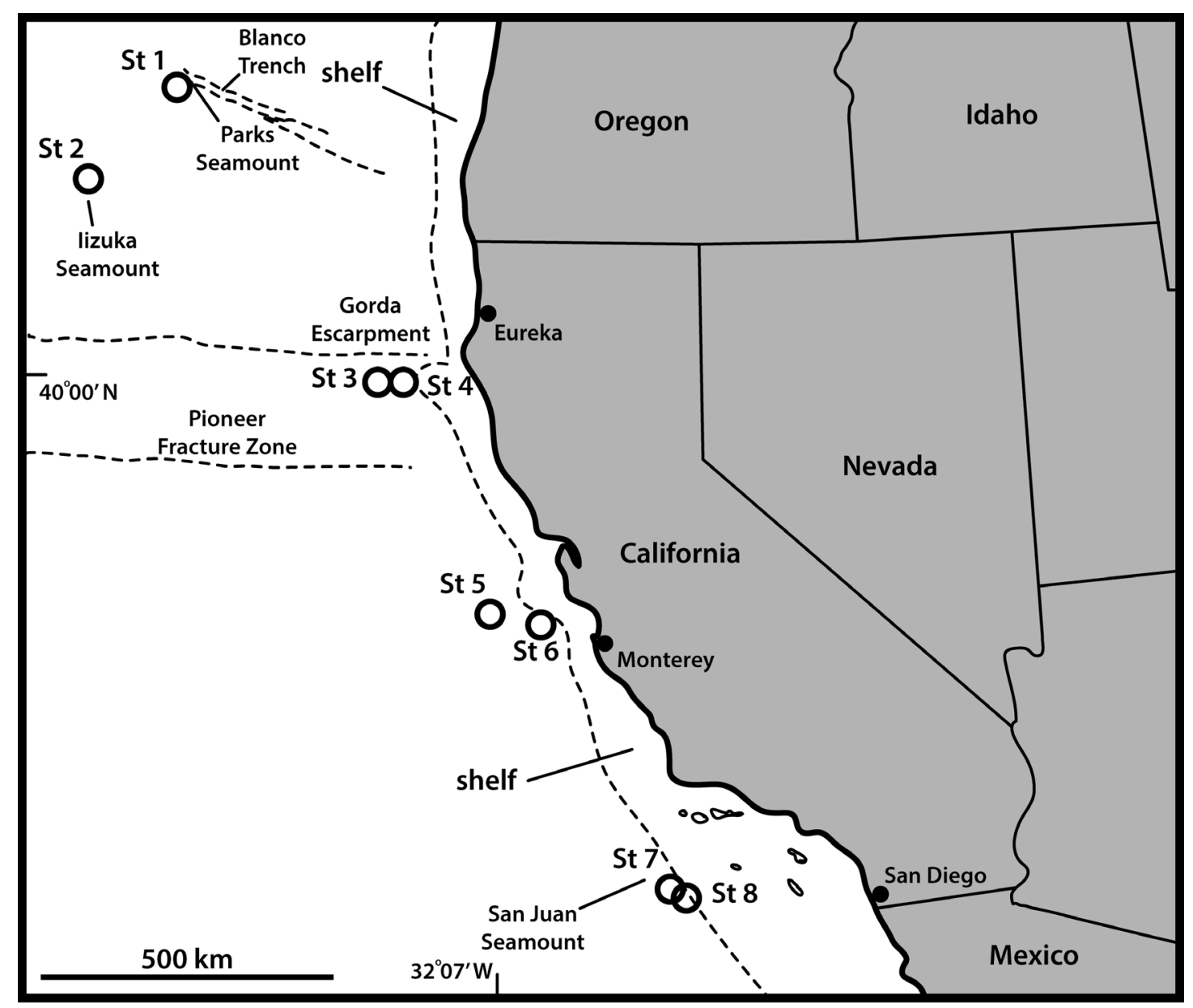

Fig. 1. Map showing the eight sampling stations off the US West Coast. See Table 1 for further details. 
Table 1 (continued on next page). Summary of data on stations, species identities, and catalogue numbers.

\begin{tabular}{|c|c|c|c|}
\hline Station & Date & Position & Species \\
\hline St. 1 & 16 Sep. 2008 & $\begin{array}{c}43^{\circ} 59^{\prime} 50^{\prime \prime} \mathrm{N} \\
130^{\circ} 23^{\prime} 36^{\prime \prime} \mathrm{W}\end{array}$ & $\begin{array}{l}3250 \mathrm{~m} \text { E. anniae sp. nov. } \\
\text { E. dubiosus sp. nov. } \\
\text { E. cf. unispinosus }\end{array}$ \\
\hline St. 2 & 17-19 Sep. 2008 & $\begin{array}{c}42^{\circ} 33^{\prime} 50^{\prime \prime} \mathrm{N} \\
131^{\circ} 59^{\prime} 48^{\prime \prime} \mathrm{W}\end{array}$ & $\begin{array}{l}3601 \mathrm{~m} \text { E. dubiosus sp. nov. } \\
\text { E. hamiltonorum sp. nov. } \\
\text { E. juliae } \text { sp. nov. } \\
\text { E. lupherorum } \text { sp. nov. }\end{array}$ \\
\hline
\end{tabular}

St. 3 20-21 Sep. 2008 3959'58" N 3675 m E. dubiosus sp. nov. $125^{\circ} 52^{\prime} 27^{\prime \prime} \mathrm{W}$

E. hamiltonorum sp. nov.
E. juliae sp. nov.
E. lupherorum sp. nov.
E. cf. unispinosus
F. higginsi

St. 4 21-22 Sep. 2008 39 59'53" N 2733 m E. dubiosus sp. nov. $125^{\circ} 26^{\prime} 36^{\prime \prime} \mathrm{W}$

$$
\text { E. hviidarum sp. nov. }
$$

E. juliae sp. nov.
E. cf. unispinosus

St. 5 23-52 Sep. 2008 36 $46^{\circ} 46^{\prime \prime} \mathrm{N} 3679$ m E. dubiosus sp. nov.

$$
123^{\circ} 41^{\prime} 54^{\prime \prime} \mathrm{W} \quad \text { E. hamiltonorum sp. nov. }
$$

\section{E. hviidarum sp. nov.}

E. juliae sp. nov.

E. cf. unispinosus

St. 6 24-25 Sep. 2008 36²40'52" N 2719 m E. dubiosus sp. nov. $122^{\circ} 49^{\prime} 37^{\prime \prime} \mathrm{W}$

E. hakaiensis
E. hamiltonorum sp. nov.
E. hviidarum sp. nov.
E. juliae sp. nov.

E. lupherorum sp. nov.

E. yamasakii sp. nov.

St. 7 27-29 Sep.2008 32 52'40"N 3853 m E. dubiosus sp. nov. $120^{\circ} 36^{\prime} 31^{\prime \prime} \mathrm{W}$

$$
\begin{aligned}
& \text { E. hviidarum sp. nov. } \\
& \text { E. yamasakii sp. nov. } \\
& \text { F. higginsi }
\end{aligned}
$$

Mounting Type status and catalogue numbers

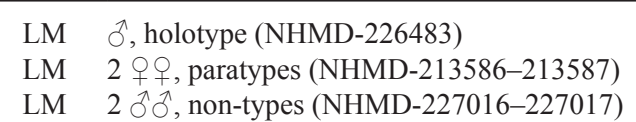

LM 1 ㅇ, paratype (NHMD-213588)

LM 2 우, paratypes (NHMD-223919-223920)

LM 1 ô, paratype (NHMD-213679)

LM + , holotype (NHMD-225220);

4 우, 1 ऽ, paratypes (NHMD-225221-225225)

LM 9 , holotype (NHMD-213583);

1 ㅇ, 1 ऽ, paratypes (NHMD-213584-213585)

LM 2 우, paratypes (NHMD-223921-223922)

SEM 1 q, non-type

LM 1 , paratype (NHMD-213680)

LM 1 9, paratype (NHMD-225226)

LM 1 万, 2 우, non-types (NHMD-227018227020)

SEM $3 \precsim \widehat{\jmath}$, non-types

LM $1 \hat{\delta}$, non-type (NHMD-227025)

LM 1 \%, paratype (NHMD-213589)

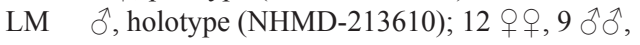
paratypes (NHMD-213611-213634)

SEM 1 , non-type

LM 1 \&, $1 \AA$, paratypes (NHMD-213681, 213683)

LM $1 \jmath, 3$ q 9 , non-types (NHMD-227021227024)

LM 2 우, paratypes (NHMD-213590-213591)

LM + , holotype (NHMD-223916); $2 \delta^{\hat{\alpha}} \sigma^{\lambda}$, paratypes (NHMD-223917-223918)

SEM 1 क, $1 \hat{\jmath}$, non-types

LM 11 우, 9 ठึ, paratypes (NHMD-213635213656)

SEM 3 우, 5 ठे $\widehat{\jmath}$, non-types

LM 2 우, 1 ô, paratypes (NHMD-213684-213686)

SEM 10 , non-type

LM $1 \delta$, paratype (NHMD-213592)

SEM 1 \&, $1 \hat{\jmath}$, non-types

LM 1 ô, non-type (NHMD-223924)

SEM 10 , non-type

LM 1 क , paratype (NHMD-223923)

SEM 2 우, $2 \lambda 0^{\lambda}$, non-types

LM 2 우, 1 ô, paratypes (NHMD-213658-13660)

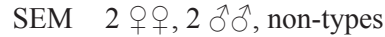

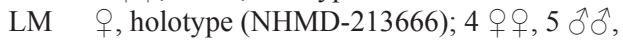
paratypes (NHMD-213667-213678)

SEM 4 우, $2 \hat{\jmath} \widehat{\jmath}$, non-types



LM $q$, holotype (NHMD-226471);3 $q$, 1 §ิ, paratypes (NHMD-226472-226475)

SEM $9+$ 우, $12 \hat{\jmath}$, non-types

SEM 1 , non-type

LM 1 क , paratype (NHMD-213661)

LM 1 +, 3 $\lesssim \hat{o}$, paratypes (NHMD-226476-226479)

SEM 1 ô non-type 


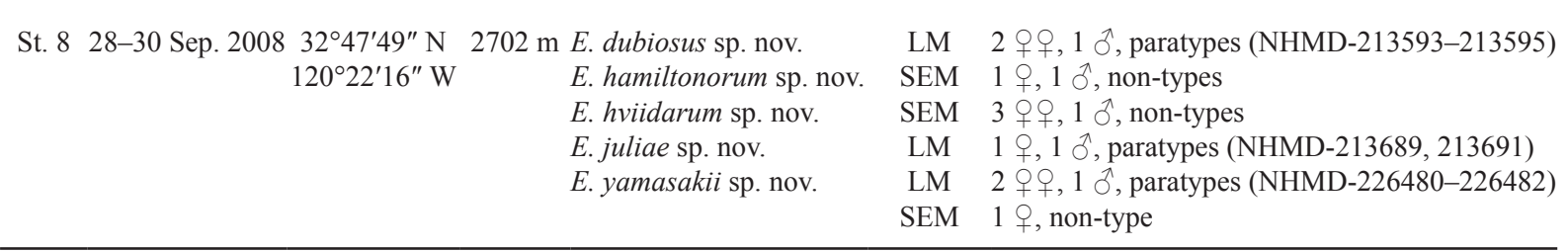

\section{Material and methods}

Samples were collected from eight stations (Fig. 1) at depths ranging from 2702 to $3853 \mathrm{~m}$ during a meiofaunal survey along the continental rise off southern Oregon and California (Rohal et al. 2014; Neves et al. in press) in September 2008. Data for each station is summarized in Table 1. Samples were taken with a multicorer, and the top $1 \mathrm{~cm}$ of sediment and overlying water in each core were transferred directly to $95 \%$ alcohol and stored at $-20^{\circ} \mathrm{C}$ until further processing. In the laboratory, the preserved samples were rinsed with tap water, the animals were stained with Rose Bengal, and subsequently sorted to main group under a stereo microscope. A total of 1086 adult and juvenile kinorhynchs were separated and transferred to slides with glycerine for long term storage.

After some years' storage, the kinorhynchs were examined in order to explore their biodiversity and taxonomy. The relatively few allomalorhagids and kentrorhagids remained stored for future examination, whereas all specimens of Echinoderidae were picked up for mounting. Specimens for light microscopy were transferred directly to Fluoromount $G$ and either mounted between a glass slide and a cover glass, or between two cover glasses attached to a plastic H-S slide. The specimens were examined and photographed with an Olympus BX51 light microscope with differential interference contrast and an Olympus DP27 camera. All examined specimens were deposited in the collection of the Natural History Museum of Denmark (NHMD) (see Table 1 for catalogue numbers).

Preparation of clean specimens for scanning electron microscopy (SEM) was challenged by the glycerine storage. Initially the specimens were rehydrated through a graded glycerine/water series. When fully rehydrated, the specimens were placed in demineralized water in an embryo dish, and, in order to wash off the remaining glycerine and dirt, a small amount of detergent (liquid hand soap or liquid dish washing detergent) was added with a Pasteur pipette. The detergent was mixed with the water, purposely creating numerous bubbles that would catch the last dirt sticking to the specimens. After two rounds of washing, the bubbles were allowed to settle, and the specimens were transferred to a new embryo dish with clean, demineralized water. After this additional wash in clean water, the specimens were transferred to SEM metal containers that were closed with $60 \mu \mathrm{m}$ nylon net at each end. The specimens were dehydrated again through a graded ethanol series, transferred to acetone through an ethanol/acetone series, and critical point dried. The dried specimens were mounted on sticky carbon tabs on SEM aluminium stubs, sputter coated with a platinum/palladium mixture, and examined with a JEOL JSM-6335F Field Emission SEM.

All photos were edited with Adobe Photoshop CS6, and figure plates and line art illustrations were prepared with Adobe Illustrator CS6. Line art illustrations were based on light microscopical images imported into Illustrator, and information from SEM was added.

Specimens from the collection of NHMD used for comparison include: the holotype and paratype of Echinoderes hakaiensis (NHMD-115709 and 115710, previously ZMUC KIN-1079 and KIN-1080), and paratypes of Echinoderes microaperturus (NHMD-99884 and 99893, previously ZMUC KIN-539 and KIN-548).

The taxonomy follows Sørensen et al. (2015). 


\section{Results}

\section{New species descriptions}

Class Cyclorhagida Zelinka, 1896 sensu Sørensen et al. 2015

Order Echinorhagata Sørensen et al., 2015

Family Echinoderidae Zelinka, 1894

Genus Echinoderes Claparède, 1863

Echinoderes anniae sp. nov.

urn:1sid:zoobank.org:act:45B173E7-B6E9-443D-8C8F-3C424183DAFD

Figs 2-3, Tables 2-3

\section{Diagnosis}

Echinoderes with middorsal spines on segments 4, 6 and 8, and spines in lateroventral positions on segments 6 to 9 . Tubes present in laterodorsal positions on segment 10, and glandular cell outlets type 2 in midlateral positions on segment 1 , in subdorsal, laterodorsal, sublateral and ventrolateral positions on segment 2 , in lateral accessory positions on segment 5 , and in sublateral positions on segment 8 . Tergal extensions of segment 11 extend into thin, flexible tips; sternal extensions short, rounded, with ventrolateral seta-like tuft of extended fringe tips. Males with three pairs of penile spines; females unknown.

\section{Etymology}

The first author (MVS) dedicates this species to his mother, Anni Larsen.

\section{Material examined}

\section{Holotype}

UNITED STATES OF AMERICA: adult ${ }^{\wedge}$, off Oregon, US West Coast, 4359'50" N, 130 $23^{\prime} 36^{\prime \prime} \mathrm{W}$, St. 1, $3250 \mathrm{~m}$ deep, collected from mud, 16 Sep. 2008, mounted on an H-S slide in Fluoromount G (NHMD226483). No other specimens were found. See Fig. 1 for locality and Table 1 for detailed station data.

\section{Description}

Adults with head, neck and eleven trunk segments (Figs 2A-B, 3A). The trunk appears stout, with very well-developed pachycycli, almost parallel-sided, and round in cross-section. Only male morphology is known. For complete overview of measurements and dimensions, see Table 2. Distribution of cuticular structures, i.e., sensory spots, glandular cell outlets, spines and tubes, is summarized in Table 3.

The head was fully retracted in the holotypic specimen; hence, no information on head morphology is available. The neck has 16 placids, measuring $12 \mu \mathrm{m}$ in length. The midventral placid is broadest, measuring $13 \mu \mathrm{m}$ in width at its base, whereas all others are narrower, measuring $9 \mu \mathrm{m}$ in width at their bases. Four dorsal and two ventral trichoscalid plates are present, with the ventral ones being broader than the four dorsal ones.

Segment 1 consists of a complete cuticular ring. Sensory spots are located on anterior segment half, but not immediately at the anterior margin, in subdorsal and laterodorsal positions (Figs 2A, 3B), and more posteriorly, in ventrolateral positions (Figs 2B, 3C). Glandular cell outlets type 2 are present in midlateral positions (Figs 2A-B, 3B-C), and glandular cell outlets type 1 in middorsal (Fig. 3B) and lateroventral positions. The segment appears to be devoid of cuticular hairs. The posterior segment margin is nearly straight, terminating in a well-developed pectinate fringe. 


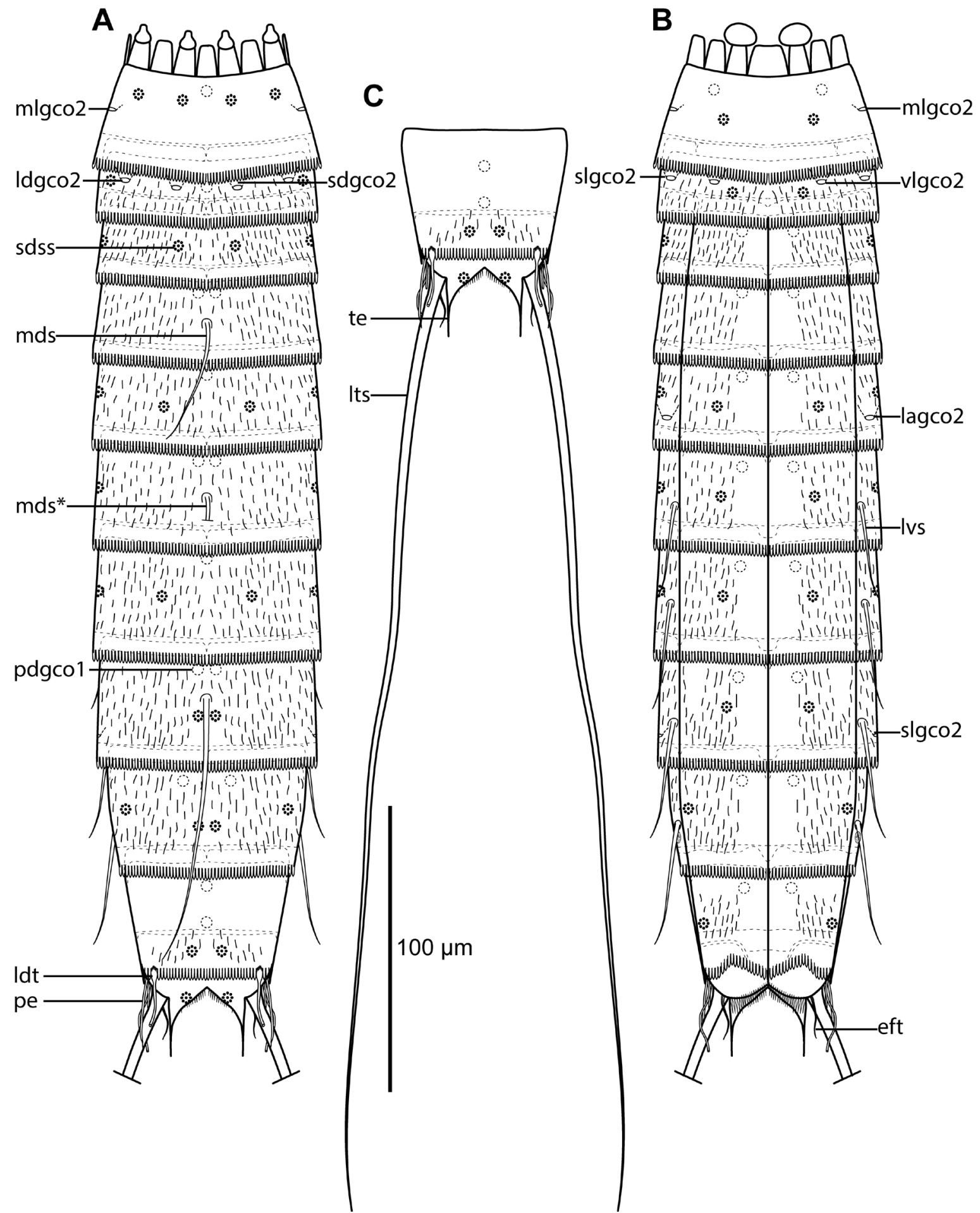

Fig. 2. Line art illustrations of Echinoderes anniae sp. nov. A. $\hat{\partial}$, dorsal view. B. $\hat{\partial}$, ventral view. C. Segments 10 to 11 in male, with lateral terminal spines drawn in full length, dorsal view. Abbreviations: eft $=$ extended fringe tips; lagco2 = lateral accessory glandular cell outlet type 2; ldgco $2=$ laterodorsal glandular cell outlet type 2; ldt = laterodorsal tube; lts = lateral terminal spine; lvs = lateroventral spine; mds $=$ middorsal spine $(*$ broken$) ;$ mlgco $2=$ midlateral glandular cell outlet type 2 ; pdgco $1=$ paradorsal glandular cell outlet type 1 ; pe = penile spines; $\operatorname{sdgco} 2=$ subdorsal glandular cell outlet type 2 ; sdss $=$ subdorsal sensory spot; $\operatorname{slgco} 2=$ sublateral glandular cell outlet type 2 ; te $=$ tergal extensions; vlgco $2=$ ventrolateral glandular cell outlet type 2 . 

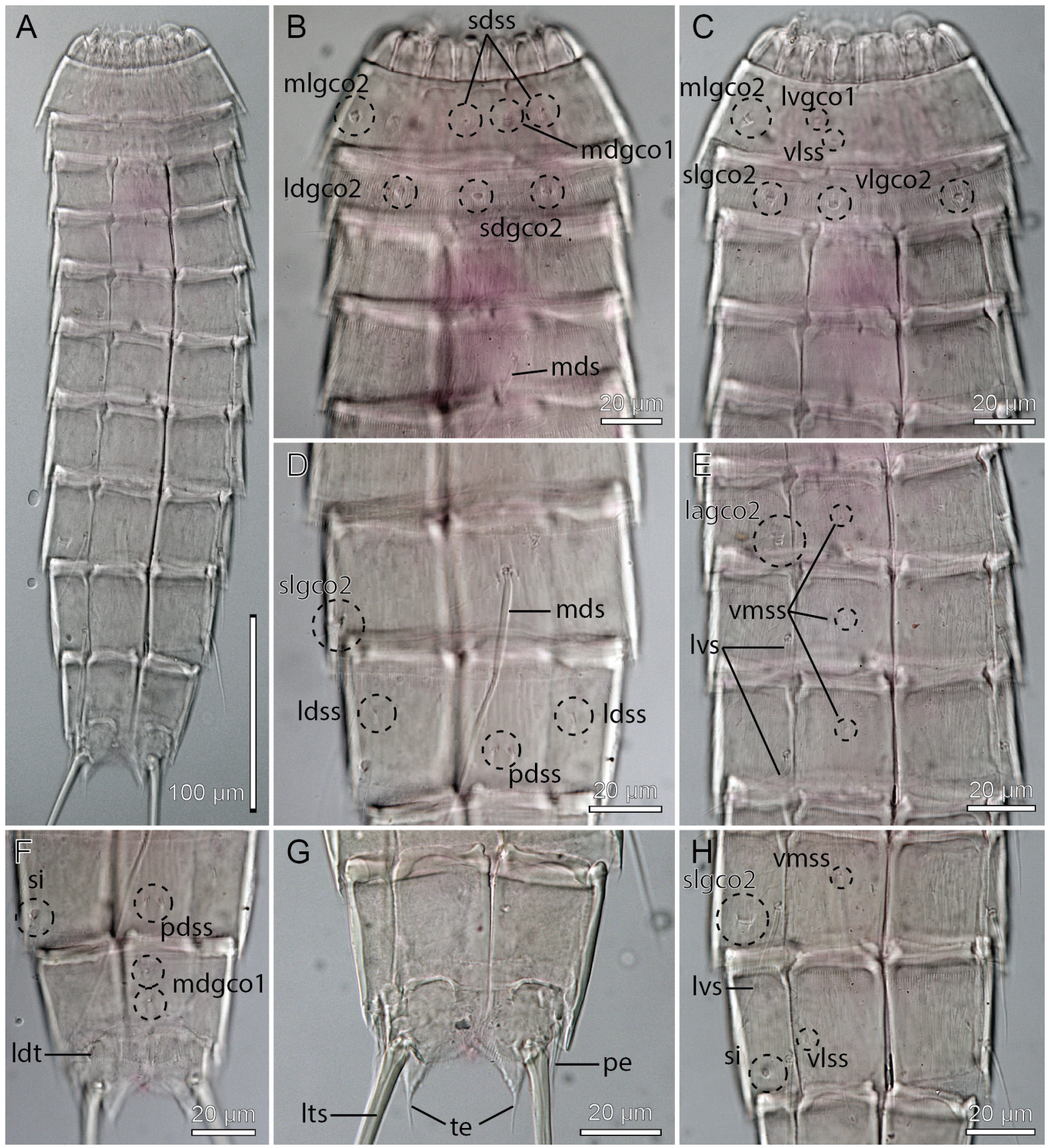

Fig. 3. Light micrographs showing overviews and details of male holotype of Echinoderes anniae sp. nov. (NHMD-226483). A. Ventral overview. B. Segments 1 to 4, dorsal view. C. Segments 1 to 4, ventral view. D. Segments 8 to 9, dorsal view. E. Segments 5 to 7, ventral view. F. Segments 9 to 11, dorsal view. G. Segments 10 to 11, ventral view. H. Segments 8 to 9, ventral view. Abbreviations: lagco $2=$ lateral accessory glandular cell outlet type 2; 1dgco2 = laterodorsal glandular cell outlet type 2; $1 \mathrm{dss}=$ laterodorsal sensory spot; $1 \mathrm{dt}=$ laterodorsal tube; $1 \mathrm{ts}=$ lateral terminal spine; 1 gecol = lateroventral glandular cell outlet type 1 ; lvs = lateroventral spine; $\operatorname{mdgco} 1=$ middorsal glandular cell outlet type 1; mds = middorsal spine; $\operatorname{mlgco} 2=$ midlateral glandular cell outlet type $2 ;$ pdss = paradorsal sensory spot; pe $=$ penile spines; $\operatorname{sdgco} 2=$ subdorsal glandular cell outlet type 2 ; sdss = subdorsal sensory spot; si = sieve plate; slgco 2 = sublateral glandular cell outlet type 2; te = tergal extensions; vlgco $2=$ ventrolateral glandular cell outlet type 2 ; vlss $=$ ventrolateral sensory spot; vmss $=$ ventromedial sensory spot. 
Table 2. Measurements from light microscopy for male holotype of Echinoderes anniae sp. nov. (in $\mu \mathrm{m})$. Abbreviations: $(\mathrm{ac})=$ acicular spine; LTS = lateral terminal spine; $\mathrm{LV}=$ lateroventral; $\mathrm{MD}$, middorsal; MSW-8 = maximum sternal width, measured on segment 8 in this species; $\mathrm{S}=$ segment lengths; SW$10=$ standard width, always measured on segment $10 ; \mathrm{TL}=$ trunk length.

\begin{tabular}{cc}
\hline Character & Length \\
\hline TL & 353 \\
MSW-8 & 61 \\
MSW-8/TL & $17.3 \%$ \\
SW-10 & 49 \\
SW-10/TL & $13.9 \%$ \\
S1 & 38 \\
S2 & 32 \\
S3 & 36 \\
S4 & 37 \\
S5 & 40 \\
S6 & 42 \\
S7 & 51 \\
S8 & 52 \\
S9 & 55 \\
S10 & 44 \\
S11 & 38 \\
MD4 (ac) & 36 \\
MD6 (ac) & missing \\
MD8 (ac) & 107 \\
LV6 (ac) & 32 \\
LV7 (ac) & 33 \\
LV8 (ac) & 36 \\
LV9 (ac) & 41 \\
LTS & 351 \\
LTS/TL & $99.4 \%$ \\
\hline
\end{tabular}

Segment 2 consists of a complete cuticular ring, with glandular cell outlets type 2 located in subdorsal, laterodorsal, sublateral and ventrolateral positions (Figs 2A-B, 3B-C). Pachycyclus of the anterior segment margin is well-developed, with weak indications of interruptions in middorsal and lateroventral positions. Sensory spots are located in laterodorsal and ventromedial positions. A single glandular cell outlet type 1 is located in middorsal position. Secondary pectinate fringe not detected on this or any of the following segments. They are evenly distributed around the segment. The posterior segment margin is nearly straight, and consists of a pectinate fringe with well-developed fringe tips.

Segment 3, and remaining segments, consist of one tergal and two sternal plates (Figs 2B, 3A, C, E, $\mathrm{G}-\mathrm{H})$. Pachycyclus of the anterior segment margin is well-developed, and interrupted at the tergosternal junctions, but also middorsally. Sensory spots are located in subdorsal and midlateral positions (Fig. 2AB). Glandular cell outlets type 1 are located in ventromedial positions (Fig. 3B). Cuticular hairs evenly distributed over tergal plate, between secondary fringe and intersegmental joint line, whereas the sternal plates only have hairs on their most lateral halves. Posterior segment margin straight, with pectinate fringe formed by well-developed fringe tips. 
Table 3. Summary of nature and location of sensory spots, glandular cell outlets, tubes and spines arranged by series in Echinoderes anniae sp. nov. Abbreviations: LA = lateral accessory; LD = laterodorsal; LV = lateroventral; $\mathrm{MD}=$ middorsal; $\mathrm{ML}=$ midlateral; $\mathrm{PD}=$ paradorsal; $\mathrm{SD}=$ subdorsal; $\mathrm{SL}=$ sublateral; $\mathrm{VL}=$ ventrolateral $\mathrm{VM}=$ ventromedial; $\mathrm{ac}=$ acicular spine; $\mathrm{gco} 1 / 2=$ glandular cell outlet type $1 / 2$; lts $=$ lateral terminal spine; pe = penile spines; $s i=$ sieve plate; $s s=$ sensory spot; tu $=$ tube; $(\widehat{\delta})=$ putative male condition of sexually dimorphic character.

\begin{tabular}{|c|c|c|c|c|c|c|c|c|c|c|}
\hline \multicolumn{11}{|c|}{ Position } \\
\hline Segment & MD & PD & SD & LD & ML & SL & LA & $\mathbf{L V}$ & VL & VM \\
\hline 1 & gco1 & & Ss & ss & gco2 & & & gcol & Ss & \\
\hline 2 & gco1 & & gco2 & gco2, ss & & gco2 & & & gco2 & ss \\
\hline 3 & & & ss & & ss & & & & & gcol \\
\hline 4 & $\mathrm{ac}$ & gcol & & & & & & & & gcol \\
\hline 5 & gcol & & ss & & ss & & gco2 & & & ss, gcol \\
\hline 6 & $\mathrm{ac}$ & gco1 & & & ss & & & $\mathrm{ac}$ & & ss, gcol \\
\hline 7 & gco1 & & ss & & ss & & & ac & & ss, gcol \\
\hline 8 & $\mathrm{ac}$ & gco1,ss & & & & gco2 & & ac & & ss, gcol \\
\hline 9 & & ss & gcol & ss & & si & & $\mathrm{ac}$ & ss & gcol \\
\hline 10 & $2 \times \mathrm{gco} 1$ & & ss & tu & & & & & ss & gcol \\
\hline 11 & & & SS & & $x \operatorname{pe}\left({ }^{\Uparrow}\right)$ & & & 1ts & & \\
\hline
\end{tabular}

Segment 4 with acicular spine in middorsal position (Figs 2A, 3B). Sensory spots not observed. Anterior part of segment with glandular cell outlets type 1 in paradorsal and ventromedial positions. Pachycycli, pectinate fringe of posterior margin and cuticular hairs as on preceding segment.

Segment 5 without spines or tubes. Glandular cell outlets type 2 present in lateral accessory positions (Figs 2B, 3E). Sensory spots present in subdorsal, midlateral and ventromedial positions, and glandular cell outlets type 1 in middorsal and ventromedial positions. Pachycycli, pectinate fringe of posterior margin and cuticular hairs as on preceding segment.

Segment 6 with acicular spines in middorsal and lateroventral positions (Figs 2A-B, 3E). Sensory spots present in midlateral and ventromedial positions, and glandular cell outlets type 1 in paradorsal and ventromedial positions. Pachycycli, pectinate fringe of posterior margin and cuticular hairs as on preceding segment.

Segment 7 with acicular spines in lateroventral positions (Figs 2B, 3E). Sensory spots present in subdorsal, midlateral and ventromedial positions, and glandular cell outlets type 1 in middorsal and ventromedial positions. Pachycycli, pectinate fringe of posterior margin and cuticular hairs as on preceding segment.

Segment 8 with acicular spines in middorsal and lateroventral positions (Fig 2A-B, 3D, H). Middorsal spine is long, reaching the posterior margin of segment 10, and slightly thicker than the middorsal spine of segment 4. Glandular cell outlets type 2 present in sublateral positions (Fig 2B, 3D, H). Sensory spots and glandular cell outlets type 1 present in paradorsal and ventromedial positions. Pachycycli, pectinate fringe of posterior margin and cuticular hairs as on preceding segment.

Segment 9 with acicular spines in lateroventral positions (Figs 2B, 3H). Sensory spots present in paradorsal, laterodorsal (Fig. 3D, F) and ventrolateral positions, and glandular cell outlets type 1 in subdorsal and ventromedial positions. Small rounded sieve plates are present in sublateral positions (Fig. 3F, H). Pachycycli, pectinate fringe of posterior margin and cuticular hairs as on preceding segment. 
Segment 10 with laterodorsal tubes at posterior segment margin (Figs 2A, 3F); tubes in males are long and well-developed (ca $9 \mu \mathrm{m}$ ); female condition of tubes is unknown. Sensory spots present in subdorsal and ventrolateral positions. Glandular cell outlets type 1 present as two middorsal ones and one pair in ventromedial positions. Tergal plate only with a few cuticular hairs on the most posterior part; sternal plates with cuticular hairs on the lateral halves, but fewer than on preceding segment. The posterior segment margin of the tergal plate is straight, and only interrupted where the laterodorsal tubes attach, whereas the margins of the sternal ones are concave, extending posteriorly near the midventral junction. Pachycycli and pectinate fringe of posterior margin as on preceding segment.

Segment 11 with lateral terminal spines, almost equal to trunk in length (Fig. 2C). Males with three pairs of thin and flexible penile spines (Figs 2A, 3G); female condition unknown. Sensory spots present in subdorsal positions near the posterior margin of the segment. The segment is completely devoid of cuticular hairs. Tergal extensions narrow gradually into long, slightly flexible tips (Fig. 3G). Sternal extensions are short and rounded. Posterior margin of sternal plates with paired tufts of extended fringe tips (Fig. 2B); they resemble ventrolateral setae, but the structures appear to be formed by long, merged fringe tips from the posterior margin.

\section{Remarks}

The new species is very easily recognized by the nature of its cuticular structures in the lateral series of segment 5 . The presence of a glandular cell outlet type 2 in lateral accessory positions is rare among congeners and shared with only E. unispinosus (Yamasaki et al. 2018b). A second trait, also exclusively shared with E. unispinosus, is the presence of midlateral glandular cell outlets type 2 on segment 1 . However, E. unispinosus has only a single middorsal spine (see below in the present contribution and Yamasaki et al. 2018b); hence, the two species are easily distinguished.

The lack of lateroventral tubes on segment 5 , combined with the presence of lateroventral spines on segments 6 to 9, is rather rare among species of Echinoderes, and only shared with E. arlis Higgins, 1966, E. drogoni, E. koreanus Adrianov in Adrianov \& Malakhov, 1999, E. orestauri Pardos, Sánchez \& Herranz, 2016 and E. svetlanae Adrianov in Adrianov \& Malakhov, 1999 (see Higgins 1966; Adrianov \& Malakhov 1999; Pardos et al. 2016a; Grzelak \& Sørensen 2018, in press). However, E. anniae sp. nov. is easily distinguished from the latter four, since they all have five middorsal spines, opposed to three in $E$. anniae sp. nov. The species shows most resemblance with E. arlis. Both species have middorsal spines on segments 4, 6 and 8, and lateroventral spines on segments 6 to 9. Echinoderes arlis does not have lateral accessory glandular cell outlets type 2 on segment 5 , but instead has sublateral tubes on this segment, but the attachment points of these tubes could be confused with gland outlets (Grzelak \& Sørensen 2018, in press). It furthermore shows the occasional presence of sublateral tubes on segment 8 (Grzelak \& Sørensen in press), and the attachment points of these tubes could also be confused with gland outlets in E. anniae sp. nov., although the gland outlets in E. anniae sp. nov. are considerably larger than the tube attachments in E. arlis. Also the nearly parallel-sided trunks and the relatively welldeveloped pachycycli give the two species a fairly similar appearance. The main differences between the two species appear to be linked to the possession of either tubes or glandular cell outlets type 2. In addition to the differences on segments 5 and 8 , the two species can be distinguished in a similar way on segment 2 . Both species have glandular cell outlets type 2 in subdorsal and sublateral positions, but they differ in the laterodorsal positions where only E. anniae sp. nov. has glandular cell outlets type 2, and in the ventrolateral positions where $E$. arlis has tubes instead of glandular cell outlets type 2 (Grzelak \& Sørensen 2018, in press). Furthermore, E. anniae sp. nov. has glandular cell outlets type 2 in midlateral positions on segment 1, which are certainly not present in E. arlis. Hence, it is possible to distinguish the two species in different ways, but the several similarities suggest a close relationship between E. anniae sp. nov. and E. arlis, and potentially also E. unispinosus. 


\section{Echinoderes dubiosus sp. nov. urn:lsid:zoobank.org:act:312B7A46-B12C-49DE-B11B-D36EE2FCA488}

Figs 4-6, Tables 4-6

\section{Diagnosis}

Echinoderes with middorsal spines on segments 4 to 8 and spines in lateroventral positions on segments 6 to 9 , with spines on segment 9 always extending beyond the terminal segment. Tubes present in lateroventral positions on segment 5 , sublateral positions on segment 8 and laterodorsal positions on segment 10; tubes on segment 10 do not show sexual dimorphism. Minute glandular cell outlets type 2 present in midlateral positions on segment 2. Segment 9 with middorsal cuticular structures, forming an anterior pore, and a posterior papillary flap, flanked by two sensory spots. Males with three pairs of penile spines; females with lateral terminal accessory spines.

\section{Etymology}

This species name dubiosus is derived from the Latin 'dubium', because of its very close resemblance with Echinoderes bathyalis, and thus slightly questionable status as a distinct species.

\section{Material examined}

\section{Holotype}

UNITED STATES OF AMERICA: adult 9 , US West Coast, off northern California, 39 $59^{\prime} 58^{\prime \prime} \mathrm{N}$, $125^{\circ} 52^{\prime} 27^{\prime \prime}$ W, St. 3, $3675 \mathrm{~m}$ deep, collected from mud, 20 Sep. 2008, mounted on glass slide in Fluoromount G (NHMD-213583). See Fig. 1 for localities and Table 1 for detailed station data.

\section{Paratypes}

UNITED STATES OF AMERICA: $1 \uparrow, 1 \hat{\jmath}$, same collecting data as for holotype; 2 + $q$, St. $1 ; 1$,

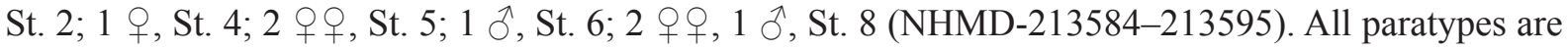
mounted in Fluoromount G, nine on glass slides and three on H-S slides.

\section{Additional non-type material}

UNITED STATES OF AMERICA: $1 \stackrel{+}{\circ} 1$, St. $6 ; 1$, St. 7. All mounted for SEM and stored in the first author's personal reference collection.

\section{Description}

Adults with head, neck and eleven trunk segments (Figs 4A-B, 5A, 6A). The trunk appears relatively slender, with very long lateral terminal spines, often exceeding the trunk length (Figs 4A-C, 5A). For a complete overview of measurements and dimensions, see Table 4. Distribution of cuticular structures, i.e., sensory spots, glandular cell outlets, spines and tubes, is summarized in Table 5.

None of the specimens mounted for SEM allowed a detailed examination of the head morphology. The neck has 16 placids, measuring $13 \mu \mathrm{m}$ in length. The midventral placid is broadest, measuring $10 \mu \mathrm{m}$ in width at its base, whereas all others are narrower, measuring $8 \mu \mathrm{m}$ in width at their bases. Four dorsal and two ventral trichoscalid plates are present, with the ventral pair being broader than the two dorsal pairs.

Segment 1 consists of a complete cuticular ring (Figs 4A-B, 5B-C). Sensory spots are located medially on the segment in subdorsal and laterodorsal positions (Figs 4A, 5B, 6B), and two glandular cell outlets type 1 in middorsal positions (Fig. 4A), and one pair in sublateral positions (Figs 4B, 6C). The segment is completely devoid of cuticular hairs, except for long hairs around the sensory spots (Fig. 6B-C). The posterior segment margin is nearly straight, terminating in a pectinate fringe with thin, but quite long fringe tips (Fig. 6B-C). 

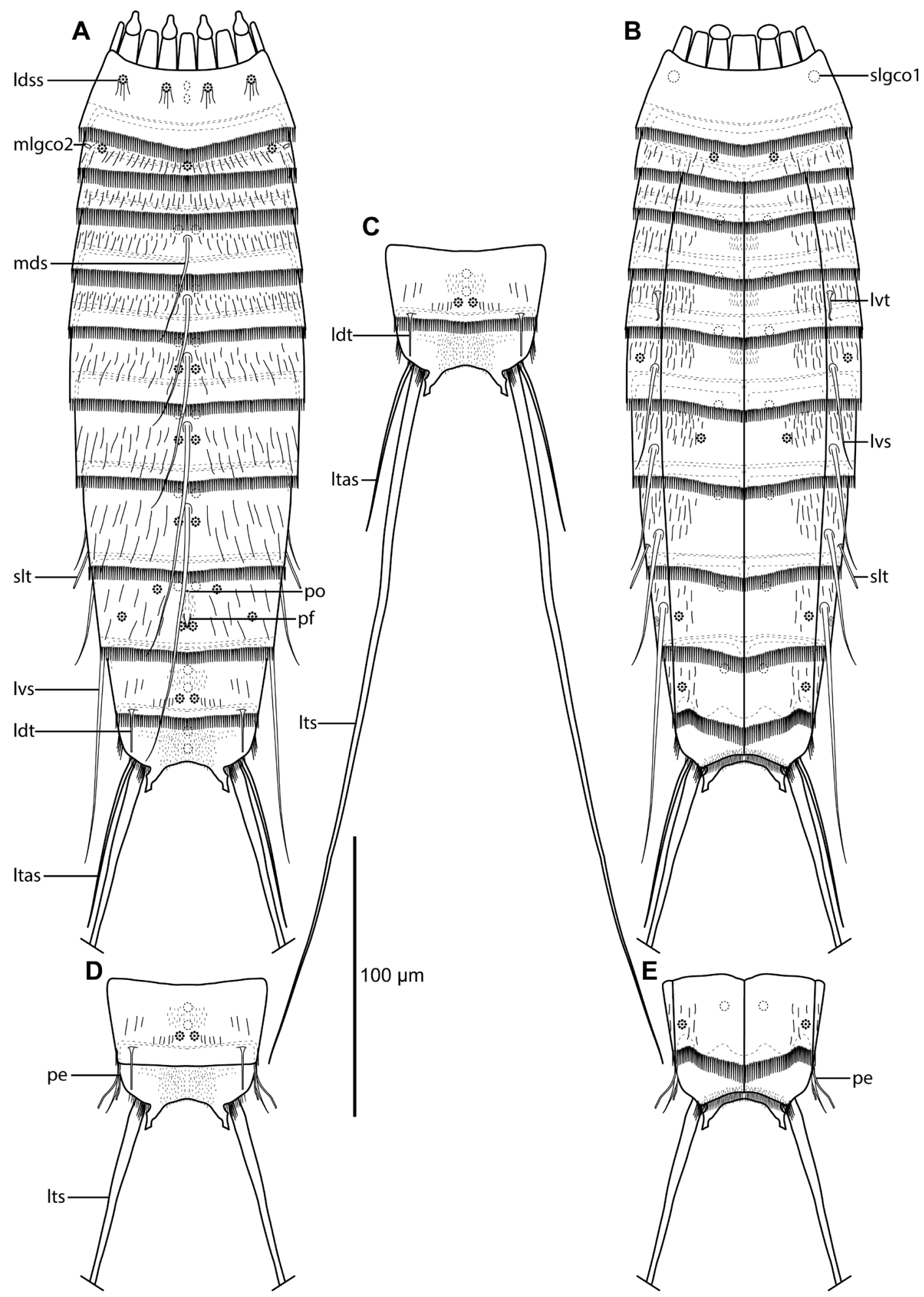

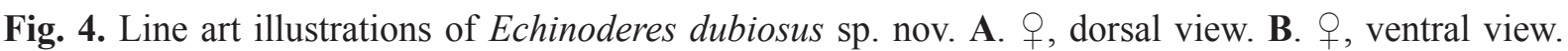

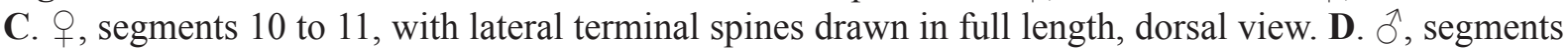
10 to 11, dorsal view. E. $\widehat{\text { O }}$, segments 10 to 11, ventral view. Abbreviations: ldss = laterodorsal sensory spot; $1 \mathrm{dt}=$ laterodorsal tube; 1 tas = lateral terminal accessory spine; $1 \mathrm{ts}=$ lateral terminal spine; lvs = lateroventral spine; $1 \mathrm{vt}=$ lateroventral tube; $\mathrm{mds}=$ middorsal spine; $\operatorname{mlgco} 2=$ midlateral glandular cell outlet type $2 ; \mathrm{pe}=$ penile spines; $\mathrm{pf}=$ papillary flap; $\mathrm{po}=$ pore; $\operatorname{slgco} 1=$ sublateral glandular cell outlet type 1 ; slt $=$ sublateral tube. 




Fig. 5. Light micrographs showing overviews and details of Echinoderes dubiosus sp. nov., holotype, $q$ (A-E, G) (NHMD-213583) and paratype, $\widehat{O}(\mathrm{~F}, \mathrm{H})$ (NHMD-213592). A. Ventral overview. B. Segments 1 to 6, dorsal view. C. Segments 1 to 6, ventral view. D. Segments 7 to 10 , dorsal view. E. Segments 8 to 11 , ventral view. F. Segments 8 to 11 , ventral view. G. Segments 10 to 11 in female, ventral view. H. Segments 10 to 11 in male, dorsal view. Abbreviations: ldss = laterodorsal sensory spot; ldt = laterodorsal tube; 1 tas $=$ lateral terminal accessory spine; 1 ts $=$ lateral terminal spine; $1 \mathrm{vs}=$ lateroventral spine; lvt $=$ lateroventral tube; $\operatorname{mdgco} 1=$ middorsal glandular cell outlet type $1 ; \mathrm{mds}=$ middorsal spine; mlgco 2 = midlateral glandular cell outlet type $2 ;$ pdgco 1 = paradorsal glandular cell outlet type $1 ; \mathrm{pe}=$ penile spines; $\mathrm{sdss}=$ subdorsal sensory spot; $\mathrm{si}=$ sieve plate; $\mathrm{slt}=$ sublateral tube; te $=$ tergal extensions; vmgco $1=$ ventromedial glandular cell outlet type 1. 
Segment 2 consists of a complete cuticular ring, with minute glandular cell outlets type 2 located in midlateral positions (Figs 4A, 5B, 6D-E). Pachycyclus of the anterior segment margin is of regular thickness and uninterrupted. Sensory spots are located in middorsal, laterodorsal (Fig. 6D) and ventromedial (Fig. 6C) positions. Secondary pectinate fringe not detected on this or any of the following segments. On this and the eight following segments, the cuticular hairs are bracteate. The fairly long hairs are arranged in only two to three rows across the tergal plate (Fig. 6B, D) and on the lateral halves of the sternal plates. The posterior segment margin is nearly straight and consists of a pectinate fringe, with fringe tips being longer and thicker than those on preceding segment, and very flexible (Fig. 6B-D).

Segment 3, and remaining segments, consisting of one tergal and two sternal plates (Figs 4A-B, 5A, C, $\mathrm{E}-\mathrm{G})$. Pachycyclus of the anterior segment margin is well-developed and interrupted at the tergosternal and midsternal junctions, but also middorsally. No conspicuous cuticular structures present. Cuticular hairs and posterior segment margin straight as on preceding segment.

Segment 4 with acicular spine in middorsal position (Figs 4A, 5B, 6G). Sensory spots not observed. Anterior part of segment with glandular cell outlets type 1 in paradorsal and ventromedial positions. Pachycycli, pectinate fringe of posterior margin and cuticular hairs as on preceding segment.

Segment 5 with acicular spine in middorsal position and minute tubes in lateroventral positions (Figs 4A-B, 5B-C, 6G). Glandular cell outlets type 1, pachycycli, pectinate fringe of posterior margin and cuticular hairs as on preceding segment.

Segment 6 with acicular spines in middorsal and lateroventral positions (Figs 4A-B, 5B, 6F-G). Sensory spots present in paradorsal (Fig. 6F) and sublateral positions. Glandular cell outlets type 1, pachycycli, pectinate fringe of posterior margin and cuticular hairs as on preceding segment.

Segment 7 with acicular spines in middorsal and lateroventral positions (Figs 4A-B, 5D, 6F-G). Sensory spots present in paradorsal (Fig. 6F) and ventromedial positions. Glandular cell outlets type 1, pachycycli, pectinate fringe of posterior margin and cuticular hairs as on preceding segment.

Segment 8 with acicular spines in middorsal and lateroventral positions (Figs 4A-B, 5D-E). Middorsal spine long, sometimes reaching or even exceeding the posterior margin of segment 11 (Fig. 4A). Rather thick and rigid tubes, without differentiated bases or lateral wings, present in sublateral positions (Figs $5 \mathrm{E}-\mathrm{F}, 6 \mathrm{~F}$ ). The exact position of the tubes varied between the examined specimens; they always stay within the sublateral area, but in some specimens, including the holotype and some paratypes, the tubes are very close to the midlateral line, whereas in others the tubes are almost in lateral accessory positions (compare Fig. 5E and 5F). The variation is not related to gender or population. Sensory spots are present in paradorsal positions only. Glandular cell outlets type 1, pachycycli, pectinate fringe of posterior margin and cuticular hairs as on preceding segment.

Segment 9 with acicular spines in lateroventral positions; the spines are thicker than other spines in the lateroventral series, and also long, always extending beyond the terminal segment (Figs 4B, 5E). A couple of uncommon cuticular structures are present in middorsal position (Figs 4A, 6K). Most anterior, it has an unpaired pore, flanked by cuticular ridges forming an inverted wedge. Posterior to this pore, a papillary flap or tuft of papillae, flanked by a pair of paradorsal sensory spots, is present. The structures are very conspicuous in SEM (Fig. 6K), but hardly visible in LM (Fig. 5D). Additional sensory spots present in subdorsal, laterodorsal and ventrolateral positions (Figs 4A-B, 5D). Small rounded sieve plates are present in sublateral positions (Figs 4B, 5F). Glandular cell outlets type 1, pachycycli, pectinate fringe of posterior margin and cuticular hairs as on preceding segment. 
Table 4. Measurements from light microscopy of Echinoderes dubiosus sp. nov. (in $\mu \mathrm{m}$ ), including number of measured specimens (n) and standard deviation (SD). Abbreviations: (ac) = acicular spine; LTAS = lateral terminal accessory spine; LTS = lateral terminal spine; LV = lateroventral; $\mathrm{MD}=$ middorsal; MSW-7 = maximum sternal width, measured on segment 7 in this species; $\mathrm{S}=$ segment lengths; SW-10 = standard width, always measured on segment $10 ; \mathrm{TL}=$ trunk length.

\begin{tabular}{ccccc}
\hline Character & n & Range & Mean & SD \\
\hline TL & 9 & $238-281$ & 259 & 13.22 \\
MSW-7 & 5 & $60-70$ & 64 & 3.91 \\
MSW-7/TL & 5 & $22.8-25.4 \%$ & $24.2 \%$ & $1.11 \%$ \\
SW-10 & 6 & $51-57$ & 53 & $2.25 \%$ \\
SW-10/TL & 6 & $19.5-22.2 \%$ & $20.4 \%$ & $0.92 \%$ \\
S1 & 9 & $30-37$ & 32 & 1.94 \\
S2 & 9 & $25-31$ & 27 & 2.06 \\
S3 & 9 & $27-31$ & 29 & 1.22 \\
S4 & 9 & $29-41$ & 33 & 3.46 \\
S5 & 9 & $32-46$ & 37 & 4.21 \\
S6 & 9 & $34-47$ & 40 & 3.50 \\
S7 & 9 & $38-49$ & 43 & 3.16 \\
S8 & 9 & $39-48$ & 45 & 2.79 \\
S9 & 9 & $40-46$ & 43 & 1.96 \\
S10 & 9 & $34-43$ & 37 & 3.24 \\
S11 & 9 & $29-35$ & 31 & 1.96 \\
MD4 (ac) & 7 & $30-52$ & 38 & 8.65 \\
MD5 (ac) & 6 & $41-78$ & 57 & 12.19 \\
MD6 (ac) & 7 & $64-87$ & 70 & 8.12 \\
MD7 (ac) & 8 & $68-93$ & 80 & 8.69 \\
MD8 (ac) & 8 & $96-136$ & 110 & 12.08 \\
LV6 (ac) & 5 & $28-56$ & 39 & 10.44 \\
LV7 (ac) & 6 & $32-68$ & 48 & 11.63 \\
LV8 (ac) & 8 & $39-91$ & 58 & 17.61 \\
LV9 (ac) & 9 & $79-120$ & 90 & 12.45 \\
LTS & 9 & $186-323$ & 263 & 42.57 \\
LTS/TL & 7 & $75.0-118.9 \%$ & $101.4 \%$ & $14.54 \%$ \\
LTAS & 9 & $61-78$ & 68 & 7.76 \\
\hline
\end{tabular}

Fig. 6 (opposite page). Scanning electron micrographs showing overviews and details of Echinoderes dubiosus sp. nov. A. Lateral overview. B. Segments 1 to 3, laterodorsal view. C. Segments 1 to 3, ventral view. D. Segments 2 to 3, lateral view. E. Detail showing minute midlateral glandular cell outlet type 2 on segment 2. F. Detail showing middorsal spines and paradorsal sensory spots on segments 6 and 7 . G. Segments 4 to 7 , left side middorsal to laterodorsal areas. H. Segments 8, lateral view. I. Segments 10 to 11 in male, laterodorsal view. J. Segments 10 to 11 in female, laterodorsal view. K. Mid- and paradorsal regions of segment 9. L. Segments 9 to 11 in male, ventral view. M. Segments 10 to 11 in female, ventral view. Abbreviations: ldss = laterodorsal sensory spot; $1 \mathrm{dt}=$ laterodorsal tube; 1 tas $=$ lateral terminal accessory spine; $1 \mathrm{ts}=$ lateral terminal spine; $1 \mathrm{vs}=$ lateroventral spine; $\mathrm{mds}=$ middorsal spine; $\operatorname{mlgco} 2=$ midlateral glandular cell outlet type 2 ; pdss $=$ paradorsal sensory spot; pe $=$ penile spines; $\mathrm{pf}=$ papillary flap; $\mathrm{po}=$ pore; sdss = subdorsal sensory spot; slgcol $=$ sublateral glandular cell outlet type 1 ; slt $=$ sublateral tube; te $=$ tergal extensions; vlss $=$ ventrolateral sensory spot; vmss $=$ ventromedial sensory spot. 
SØRENSEN M.V. et al., Deep-sea Echinoderidae from the Northwest Pacific
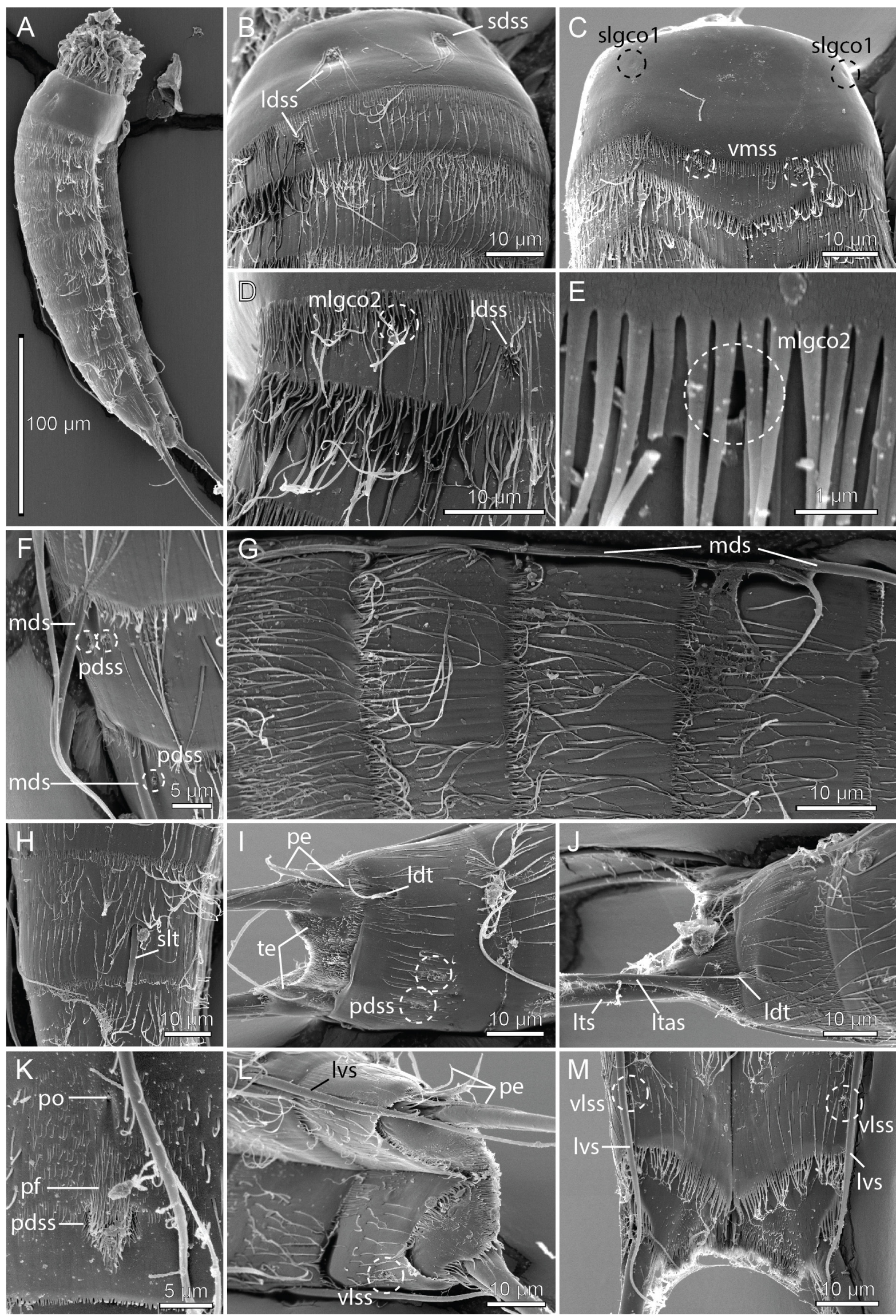
Table 5. Summary of nature and location of sensory spots, glandular cell outlets, tubes and spines arranged by series in Echinoderes dubiosus sp. nov. Abbreviations: LA = lateral accessory; LD = laterodorsal; $\mathrm{LV}=$ lateroventral; $\mathrm{MD}=$ middorsal; $\mathrm{ML}=$ midlateral; $\mathrm{PD}=$ paradorsal; $\mathrm{SD}=$ subdorsal; $\mathrm{SL}=$ sublateral; $\mathrm{VL}=$ ventrolateral; $\mathrm{VM}=$ ventromedial; $\mathrm{ac}=$ acicular spine; gco $1 / 2=$ glandular cell outlet type $1 / 2$; ltas = lateral terminal accessory spine; lts = lateral terminal spine; $p e=$ penile spines; $\mathrm{pf}=$ papillary flap; $\mathrm{po}=$ pore; $\mathrm{si}=$ sieve plate; $\mathrm{ss}=$ sensory spot; $\mathrm{tu}=$ tube; $($ + $)=$ female and $\left({ }^{\Uparrow}\right)=$ male conditions of sexually dimorphic characters.

\begin{tabular}{|c|c|c|c|c|c|c|c|c|c|c|}
\hline \multicolumn{11}{|c|}{ Position } \\
\hline Segment & MD & PD & SD & LD & ML & SL & LA & LV & VL & VM \\
\hline 1 & gco1, gco1 & & ss & SS & & gco1 & & & & \\
\hline 2 & ss & & & ss & $\operatorname{gco} 2$ & & & & & SS \\
\hline 3 & & & & & & & & & & \\
\hline 4 & $\mathrm{ac}$ & gco1 & & & & & & & & gco1 \\
\hline 5 & $\mathrm{ac}$ & gcol & & & & & & tu & & gcol \\
\hline 6 & $\mathrm{ac}$ & ss, gcol & & & & ss & & $\mathrm{ac}$ & & gcol \\
\hline 7 & $\mathrm{ac}$ & ss, gcol & & & & & & $\mathrm{ac}$ & & ss, gco1 \\
\hline 8 & $\mathrm{ac}$ & ss, gcol & & & & tu & & $\mathrm{ac}$ & & gcol \\
\hline 9 & po,pf & ss, gcol & ss & ss & & si & & $\mathrm{ac}$ & ss & gcol \\
\hline 10 & gco1, gco1 & ss & & tu & & & & & ss & gco1 \\
\hline 11 & gcol, gcol & & & & $\mathrm{xpe}\left(\mathrm{O}^{\pi}\right)$ & & $\operatorname{ltas}(P)$ & lts & & \\
\hline
\end{tabular}

Segment 10 with laterodorsal tubes near posterior segment margin; tubes are long and thin, with bases and lateral wings in both sexes (Figs 4A, D, 5H, 6I-J). Sensory spots present in paradorsal and ventrolateral positions (Figs 4A-B, 6I, L-M). Glandular cell outlets type 1 present as two middorsal ones and one pair in ventromedial positions (Fig. 5E-F, H). Cuticular hairs scarcer than on preceding segments. The posterior segment margin of the tergal plate is straight; in females it terminates in a pectinate fringe with shorter fringe tips, whereas the fringe is hardly seen in males (Fig. 6I). The margins of the sternal ones are concave, extending posteriorly near the midventral junction (Fig. 6M); pectinate fringe with long fringe tips present in both sexes. Pachycycli as on preceding segment.

Segment 11 with lateral terminal spines, nearly equal in length to or longer than trunk length (Figs 4C, 5A). Males with three pairs of penile spines; dorsal and ventral penile spines are thin, flexible tubes, whereas the median ones are thicker and conical, yet flexible (Figs 4D-E, 5H, 6I, L); females with lateral terminal accessory spines (Figs 4A-B, 5G, 6J). No sensory spots observed. Glandular cell outlets type 1 present as two middorsal ones (Fig. 5H). The segment is completely devoid of cuticular hairs, but densely covered with short hair-like extensions, in middorsal to laterodorsal areas, and along the ventral margin (Fig. 6I, L-M). Tergal extensions are short and pointed, with an extra tooth at the inferior margin (Figs 4, 5G, 6I). Sternal extensions not present. Posterior margin of sternal plates with slightly longer fringe tips near the insertion of the lateral terminal spines.

\section{Remarks}

With middorsal spines on segments 4 to 8 and lateroventral tubes/spines on segments 5 to 9 , E. dubiosus sp. nov. has the most common spine formula among species of Echinoderes. But still, the species is easily distinguished from most of its congeners by its thick and very long lateroventral spines on segment 9, combined with the presence of only midlateral glandular cell outlets type 2 on segment 2 and sublateral tubes on segment 8 . Even though the spines on segment 9 usually are the longest in the lateroventral series of Echinoderes, they rarely reach the posterior margin of segment 10. Lateroventral spines of segment 9 extending beyond the posterior margin of the terminal segment is only known from 
SØRENSEN M.V. et al., Deep-sea Echinoderidae from the Northwest Pacific

E. dubiosus sp. nov., E. bathyalis and females of Echinoderes levanderi Karling, 1954 (Yamasaki et al. 2018a; Sørensen 2018).

Moreover, the presence of glandular cell outlets type 2 in midlateral positions only on segment 2 is nearly unique among its congeners, and shared only with E. bathyalis. In general, whereas laterodorsal or sublateral glandular cell outlets type 2 on segment 2 are fairly common among species of Echinoderes, only two other species, E. aquilonius Higgins \& Kristensen, 1988 and E. pennaki Higgins, 1960, have glandular cell outlets type 2 in midlateral positions of this segment. However, these two species have 2 and 3 pairs of glandular cell outlets type 2 on segment 2, respectively, and additional pairs on segments 4, 5 and 8 (for E. aquilonius see Grzelak and Sørensen 2018; for E. pennaki see Herranz et al. 2018).

Hence, E. dubiosus sp. nov. is very easily distinguished from most congeners, except for E. bathyalis with which it shows a very close resemblance. Echinoderes bathyalis is also described from deep waters (2721-2875 m deep), but in the East Atlantic, near Sedlo Seamount, off the Azores. The two species have identical spine patterns, and E. bathyalis is also characterized by having long lateroventral spines on segment 9, extending well beyond the terminal segment. However, the middorsal spine of segment 9 in E. bathyalis appears to be longer than the one in E. dubiosus sp. nov., and always extending well beyond the terminal segment. In E. dubiosus sp. nov. it extends to the posterior margin of segment 11 only. Both species have tubes on segment 5 , but, whereas they are present in lateroventral positions in E. dubiosus sp. nov., the tubes are slightly displaced to lateral accessory positions in E. bathyalis (Yamasaki et al. 2018a). Furthermore, unlike E. bathyalis, E. dubiosus sp. nov. also has sublateral tubes on segment 8 . We would treat this latter difference with some caution though, because even though Yamasaki et al. (2018a) confirm the lack of such a tube in E. abyssalis, they note that one specimen has indications of a glandular cell outlet type 2 in lateral accessory positions on segment 8 . Since the attachment sites of tubes sometimes resemble glandular cell outlets type 2, and the actual tubes may be difficult to visualize in LM, we cannot reject the possibility that some specimens of E. bathyalis have tubes on segment 8 in nearly the same positions as $E$. dubiosus sp. nov. During the preparation of the present description we contacted Dr Yamasaki regarding the nature of this structure in E. bathyalis and he confirmed that it was only observed in one specimen (out of three), that it seemed to be a glandular cell outlet type 2, rather than a tube, and that the position was clearly lateral accessory rather than sublateral (H. Yamasaki, pers. comm.). Hence, even though the differences are subtle, we would still consider them as diagnostic. Echinoderes dubiosus sp. nov. furthermore has laterodorsal tubes on segment 10. Such tubes are missing in E. bathyalis. However, Yamasaki (pers. comm.) could not confirm the absence of such tubes in E. bathyalis with complete certainty, because they sometimes are very difficult to see with LM. The two species also seem to differ from each other in their distribution of sensory spots though. Echinoderes bathyalis has no laterodorsal sensory spots on segment 2, but quite distinct subdorsal sensory spots on segment 3 (Yamasaki et al. 2018a, and subsequently confirmed by Yamasaki, pers. comm.). SEM images of E. dubiosus sp. nov. quite clearly show the presence of laterodorsal sensory spots on segment 2 (Fig. 6D) and confirm their absence in subdorsal positions on segment 3 (Fig. 6B). Finally, E. dubiosus sp. nov. has an unusual papillary flap in middorsal position on segment 9. This structure seems to be absent in E. bathyalis, but as stressed above, the structure is very difficult to visualize with LM. According to Yamasaki (pers. comm.) a similar middorsal structure could "possibly be present" in E. bathyalis also.

Hence, in summary, E. dubiosus sp. nov. and E. bathyalis can be distinguished by the proportionally longer middorsal spine of segment 9 in E. bathyalis, and in differences in sensory spot positions on the tergal plates of segments 2 and 3 . Additional potential differences are the presence/absence of tubes on segments 8 and 10, and a middorsal papillary flap on segment 9 . Despite the subtle differences, we 
would consider the two species to be distinct, but the resemblance clearly indicates that they are very closely related in spite of the geographic distance.

One of the noteworthy traits in E. dubiosus sp. nov. is the unusual presence of middorsal structures on segment 9. Middorsal structures in Echinoderes usually include acicular spines, glandular cell outlets type 1 and sensory spots. Some species also have an extending protuberance, but this structure would always be protruding from the intersegmental joint between segments 10 and 11 (see, e.g., E. augustae Sørensen \& Landers, 2014, E bookhouti Higgins, 1964, and E. charlotteae Sørensen, Herranz \& Landers, 2016 (Sørensen \& Landers 2014; Sørensen et al. 2016a)). Segment 9 of E. dubiosus sp. nov., however, has an unpaired, middorsal pore, flanked by cuticular ridges anterior to a papillary flap or tuft of papillae, which again is flanked by a pair of paradorsal sensory spots. Such an arrangement has not been reported from any other kinorhynch. We do know, however, about three other cases of uncommon middorsal structures among species of Echinoderes, and, interestingly, they also appear on segment 9. The description of E. gizoensis Thormar \& Sørensen, 2010 reports on segment 9 the presence of a middorsal: "...elongate fringed area of filiform cuticular extensions, with a small pore", situated between a pair of paradorsal sensory spots (Thormar \& Sørensen 2010). This structure somehow resembles the anterior middorsal pore in E. dubiosus sp. nov., even though the new species lacks the filiform cuticular extensions. But then again, the structure in E. gizoensis might also simply be a single-pored sensory spot with very long papillae. The other unusual middorsal structure on segment 9 was reported from E. levanderi. In the species' recent redescription, Sørensen (2018) mentioned that a “..cuticular depression or scar, lined with short hairs is present in middorsal position, in between the paradorsal sensory spots", and a nearly similar structure is found in E. yamasakii sp. nov. (see description below). Again, it is suggestive that this puzzling middorsal structure also appears on segment 9 , and, as in the case of E. gizoensis and E. dubiosus sp. nov., is flanked by paradorsal sensory spots, but besides this, it is hard to argue for or against a homology between any of these structures. Sørensen (2018) was furthermore slightly reluctant about the nature of this structure because it was visible in SEM only, and only one SEM specimen was orientated in a way that allowed examination of the middorsal position of segment 9. The observations from the four species suggest though, that extra attention should be paid to similar structures in future descriptions.

Echinoderes hamiltonorum sp. nov. urn:1sid:zoobank.org:act:B3EE641D-72E3-4BCA-A4A9-3AD3A9BD8C05

Figs 7-9, Tables 6-7

\section{Diagnosis}

Echinoderes with middorsal spines on segments 4, 6 and 8, and spines in lateroventral positions on segments 6 to 9. Tubes present in ventrolateral positions on segment 2, in lateroventral positions on segment 5, and in laterodorsal positions on segment 10. Minute glandular cell outlets type 2 present in sublateral positions on segment 1, and in subdorsal, laterodorsal and sublateral positions on segment 2. Larger glandular cell outlets type 2 may or may not be present in sublateral positions on segment 8 . Males with three pairs of penile spines; females with lateral terminal accessory spines.

\section{Etymology}

The second author (MR) dedicates this species to her mother and the Hamiltons, i.e., her mother's side of the family, for always being there, supporting her and helping her achieve her dreams. 


\section{Material examined}

\section{Holotype}

UNITED STATES OF AMERICA: adult $q$, US West Coast, central California, off Monterey, $36^{\circ} 47^{\prime} 46^{\prime \prime} \mathrm{N}$, $123^{\circ} 41^{\prime} 54^{\prime \prime}$ W, St. 5, 3679 m deep, collected from mud, 23 Sep. 2008, mounted in Fluoromount G on a glass slide (NHMD-223916). See Fig. 1 for localities and Table 1 for detailed station data.

\section{Paratypes}

UNITED STATES OF AMERICA: $2 \hat{\jmath} \widehat{\jmath}$, same collecting data as for holotype; 2 우, St. $2 ; 2$ 우, St. 3; 1 क, St. 6 (NHMD-223917-223923). All paratypes are mounted in Fluoromount G on glass slides.

\section{Additional non-type material}

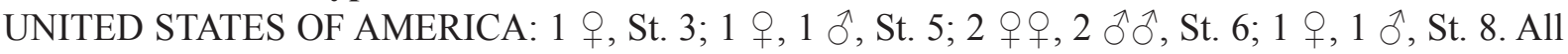
specimens mounted for SEM and stored in the first author's personal reference collection.

\section{Description}

Adults with head, neck and eleven trunk segments (Figs 7A-B, 8A, 9A-B). The species is quite small, and trunk and sternal plates appear nearly parallel-sided from segments 2 to 8 (Fig. 8A). Intraspecific variation is present on segment 8 where some specimens, but not all, independent of gender and population may have a pair of sublateral glandular cell outlets type 2 . Lateral terminal spines are relatively short and slender, $40 \%$ to $65 \%$ of trunk length (Figs $7 \mathrm{~A}-\mathrm{B}, 8 \mathrm{~A}$ ). For complete overview of measurements and dimensions, see Table 6. Distribution of cuticular structures, i.e., sensory spots, glandular cell outlets, spines and tubes, is summarized in Table 7.

The head consists of a retractable mouth cone and an introvert (Fig. 9C-D). Inner oral styles are present, but their exact number and arrangement could not be determined. The external mouth cone armature consists of nine outer oral styles, each with five basal fringe tips (Fig. 9C). The introvert sectors are defined by ten primary spinoscalids in Ring 01 . Each primary spinoscalid consists of a basal sheath and a distal end piece with a blunt tip. The basal sheaths have marginal extensions forming two layers of transverse fringes. End pieces are smooth. The arrangement of scalids follows the same pattern as in Echinoderes hviidarum sp. nov. described below; hence, see Fig. 11 for a complete overview. All spinoscalids in these rings consist of a basal sheath and a pointed end piece (Fig. 9D). The basal sheaths terminate in fringed margins on spinoscalids of Rings 02 and 04, whereas the sheaths of Ring 03 have a median spike only. Spinoscalids of Rings 05 to 07 are composed as those in the preceding ring, but with shorter end pieces.

The neck has 16 placids, measuring $10 \mu \mathrm{m}$ in length. The midventral placid is broadest, measuring $11 \mu \mathrm{m}$ in width at its base, whereas all other are narrower, measuring $7 \mu \mathrm{m}$ in width at their bases. Four dorsal and two ventral trichoscalid plates are present; the plates are well-developed and hat-shaped (Fig. 7A-B).

Segment 1 consists of a complete cuticular ring. A pair of minute glandular cell outlets type 2 is present in sublateral positions (Figs 7B, 8C, F, 9E-F). Sensory spots are located medially on the segment in subdorsal and laterodorsal positions (Figs 7A, 8B) (laterodorsal sensory spots are missing in one nontype specimen, Fig. 9E); sensory spots on this and following nine segments are medium-sized, with a tuft of micropapillae and long marginal cuticular hairs. Glandular cell outlets type 1 present in middorsal and ventrolateral positions (Figs 7A-B, 9F). Cuticular hairs arranged in a single transverse row near posterior segment margin. The posterior segment margin is straight, terminating in a pectinate fringe with rather long and flexible fringe tips. 


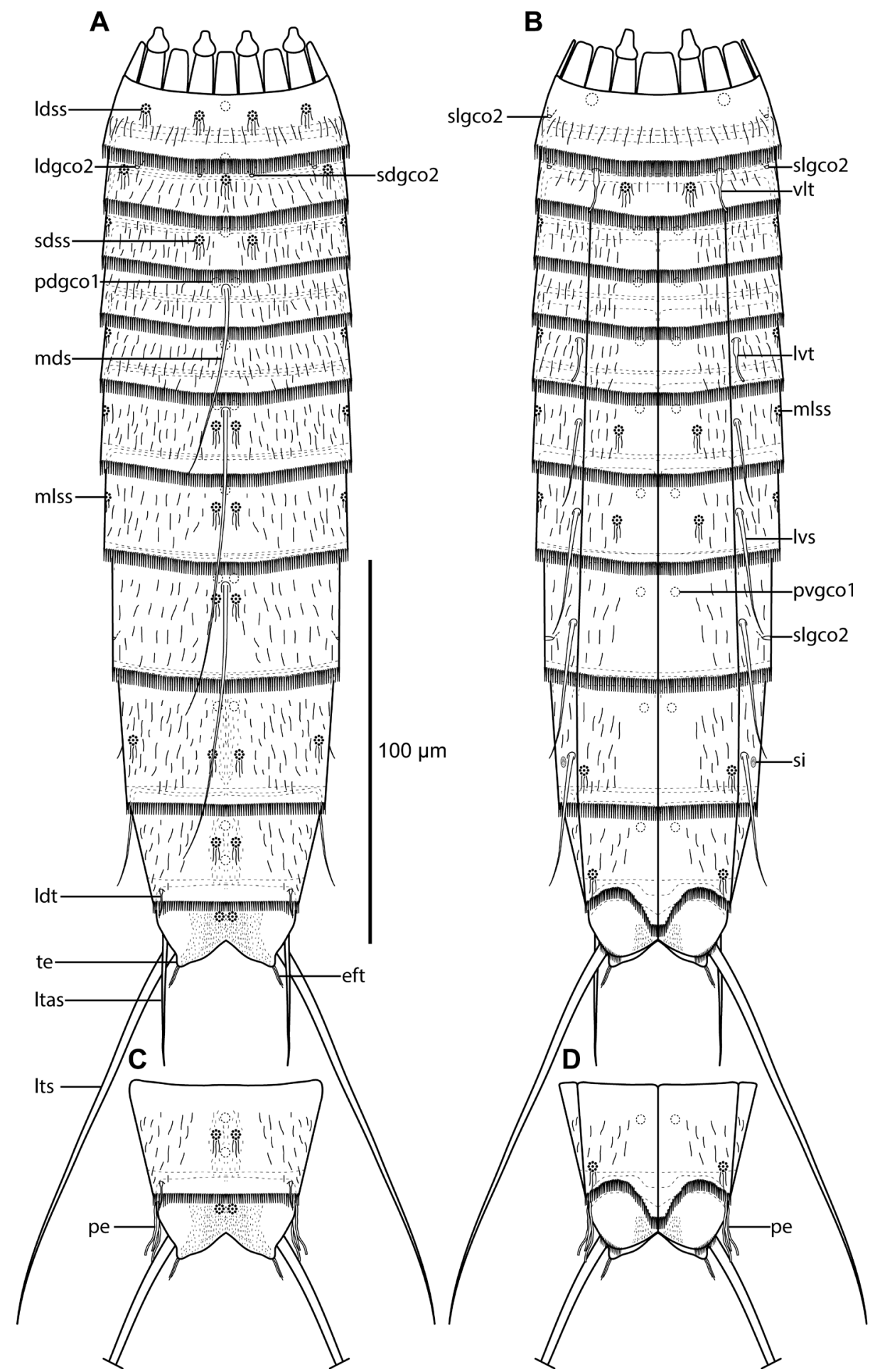

Fig. 7. Line art illustrations of Echinoderes hamiltonorum sp. nov. A. $\uparrow$, dorsal view. B. $q$, ventral view. C. $\hat{\jmath}$, segments 10 to 11 , dorsal view. D. $\hat{\partial}$, segments 10 to 11 , ventral view. Abbreviations: eft $=$ extended fringe tips; 1 dgco $2=$ laterodorsal glandular cell outlet type 2 ; ldss $=$ laterodorsal sensory spot; $1 \mathrm{dt}=$ laterodorsal tube; 1 tas = lateral terminal accessory spine; $1 \mathrm{ts}=$ lateral terminal spine; $1 \mathrm{vs}=$ lateroventral spine; $1 \mathrm{vt}=$ lateroventral tube; $\mathrm{mds}=$ middorsal spine; $\operatorname{mlss}=$ midlateral sensory spot; pdgco 1 = paradorsal glandular cell outlet type $1 ;$ pe = penile spines; pvgco1 = paraventral glandular cell outlet type $1 ; \operatorname{sdgco} 2=$ subdorsal glandular cell outlet type 2 ; sdss = subdorsal sensory spot; si = sieve plate; $\operatorname{slgco} 2=$ sublateral glandular cell outlet type 2 ; te = tergal extensions; vlt = ventrolateral tube. 

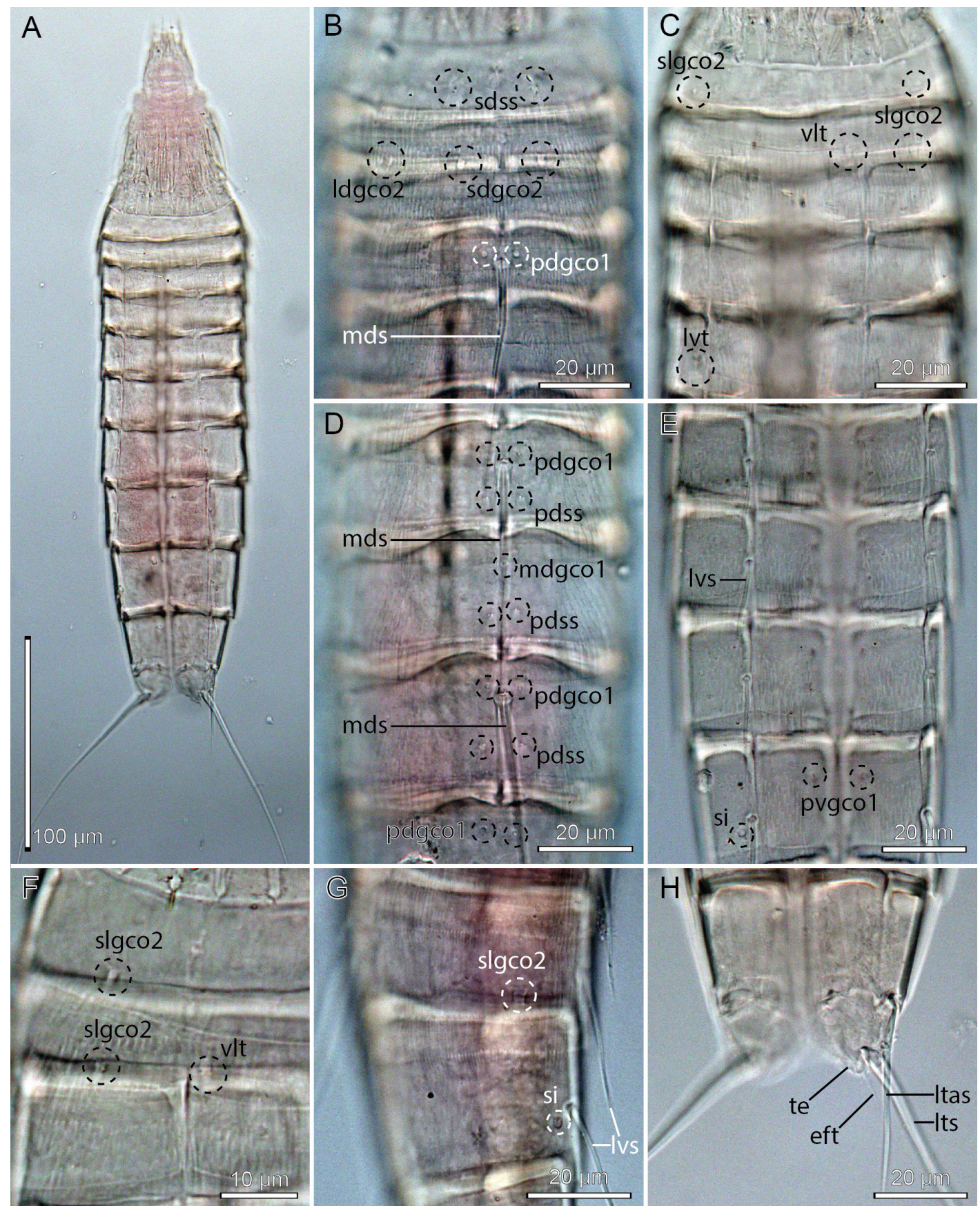

Fig. 8. Light micrographs showing overviews and details of Echinoderes hamiltonorum sp. nov., holotype, + (A-D, H) (NHMD-223916), paratype, ô (E-F) (NHMD-223918) and paratype, o (G) (NHMD-223920). A. Ventral overview. B. Segments 1 to 5, dorsal view. C. Segments 1 to 5, ventral view. D. Segments 6 to 8, dorsal view. E. Segments 6 to 9, ventral view. F. Detail showing sublateral glandular cell outlets type 2 on segments 1 and 2. G. Segments 8 to 9, lateral view. H. Segments 10 to 11 in female, ventral view. Abbreviations: eft $=$ extended fringe tips; $1 \mathrm{dgco} 2=$ laterodorsal glandular cell outlet type 2 ; las = lateral terminal accessory spine; lts = lateral terminal spine; lvs = lateroventral spine; lvt = lateroventral tube; $\mathrm{mdgco} 1=$ middorsal glandular cell outlet type $1 ; \mathrm{mds}=$ middorsal spine; pdgco1 = paradorsal glandular cell outlet type 1 ; pdss = paradorsal sensory spot; pvgco1 = paraventral glandular cell outlet type 1; sdgco2 = subdorsal glandular cell outlet type 2; sdss = subdorsal sensory spot; $\mathrm{si}=$ sieve plate; $\operatorname{slgco} 2=$ sublateral glandular cell outlet type $2 ;$ te $=$ tergal extensions; vlt $=$ ventrolateral tube. 
Table 6. Measurements from light microscopy of Echinoderes hamiltonorum sp. nov. (in $\mu \mathrm{m}$ ), including number of measured specimens (n) and standard deviation (SD). Abbreviations: (ac) = acicular spine; LTAS = lateral terminal accessory spine; LTS = lateral terminal spine; LV = lateroventral; $\mathrm{MD}=$ middorsal; MSW-8 = maximum sternal width, measured on segment 8 in this species; $\mathrm{S}=$ segment lengths; SW-10 = standard width, always measured on segment $10 ; \mathrm{TL}=$ trunk length.

\begin{tabular}{ccccc}
\hline Character & n & Range & Mean & SD \\
\hline TL & 7 & $197-263$ & 233 & 21.20 \\
MSW-8 & 4 & $42-46$ & 44 & 2.06 \\
MSW-8/TL & 4 & $17.7-19.3 \%$ & $18.5 \%$ & $0.83 \%$ \\
SW-10 & 4 & $36-41$ & 39 & $2.36 \%$ \\
SW-10/TL & 4 & $15.1-17.3 \%$ & $16.4 \%$ & $0.99 \%$ \\
S1 & 7 & $24-28$ & 27 & 1.62 \\
S2 & 7 & $21-27$ & 24 & 1.77 \\
S3 & 7 & $24-28$ & 26 & 1.40 \\
S4 & 7 & $26-32$ & 29 & 2.44 \\
S5 & 7 & $28-34$ & 32 & 2.57 \\
S6 & 7 & $31-37$ & 34 & 2.37 \\
S7 & 7 & $36-42$ & 38 & 2.24 \\
S8 & 7 & $36-42$ & 40 & 2.08 \\
S9 & 7 & $39-47$ & 42 & 2.85 \\
S10 & 7 & $29-35$ & 32 & 2.04 \\
S11 & 7 & $22-37$ & 24 & 1.95 \\
MD4 (ac) & 7 & $41-63$ & 54 & 7.72 \\
MD6 (ac) & 7 & $59-88$ & 74 & 10.80 \\
MD8 (ac) & 7 & $64-87$ & 75 & 10.68 \\
LV6 (ac) & 6 & $20-28$ & 24 & 3.39 \\
LV7 (ac) & 7 & $21-28$ & 25 & 2.93 \\
LV8 (ac) & 7 & $24-30$ & 27 & 2.29 \\
LV9 (ac) & 7 & $23-33$ & 28 & 3.99 \\
LTS & 7 & $102-149$ & 125 & 20.10 \\
LTS/TL & 7 & $42.5-65.4 \%$ & $53.8 \%$ & $8.81 \%$ \\
LTAS & 5 & $34-43$ & 39 & 4.04 \\
\hline
\end{tabular}

Fig. 9 (opposite page). Scanning electron micrographs showing overviews and details of Echinoderes hamiltonorum sp. nov. A. Lateral overview. B. Ventral overview. C. Mouth cone. D. Introvert sector 8. E. Segments 1 to 3, dorsolateral view; note that laterodorsal sensory spots are missing in this particular specimen. F. Segments 1 to 3, ventral view. G. Detail showing lateral side of segment 8 without any indication of glandular cell outlets type 2. H. Segments 8 to 9 , lateral view. I. Detail showing midlateral to lateroventral parts of segments 5 and 6 . J. $\sigma^{\hat{\alpha}}$, segments 10 to 11 , dorsolateral view. K. $\hat{\sigma}^{\lambda}$, segments 10 to 11 , ventral view. L. + , segments 10 to 11, laterodorsal view. Abbreviations: ldgco 2 = laterodorsal glandular cell outlet type 2; ldss = laterodorsal sensory spot; ldt = laterodorsal tube; ltas = lateral terminal accessory spine; lts = lateral terminal spine; lvs = lateroventral spine; lvt = lateroventral tube; mdss $=$ middorsal sensory spot; $\mathrm{mlss}=$ midlateral sensory spot; oos $=$ outer oral style; pdss $=$ paradorsal sensory spot; pe = penile spines; psp = primary spinoscalid; sdgco $2=$ subdorsal glandular cell outlet type 2; sdss = subdorsal sensory spot; $\mathrm{si}=$ sieve plate; $\operatorname{slgco} 2=$ sublateral glandular cell outlet type 2; $\mathrm{sp}=$ spinoscalid followed by introvert ring number; te $=$ tergal extensions; $\operatorname{tr}=$ trichoscalid; vlgco $1=$ ventrolateral glandular cell outlet type 1 ; vlss = ventrolateral sensory spot; vlt = ventrolateral tube; vmss $=$ ventromedial sensory spot. 
SØRENSEN M.V. et al., Deep-sea Echinoderidae from the Northwest Pacific

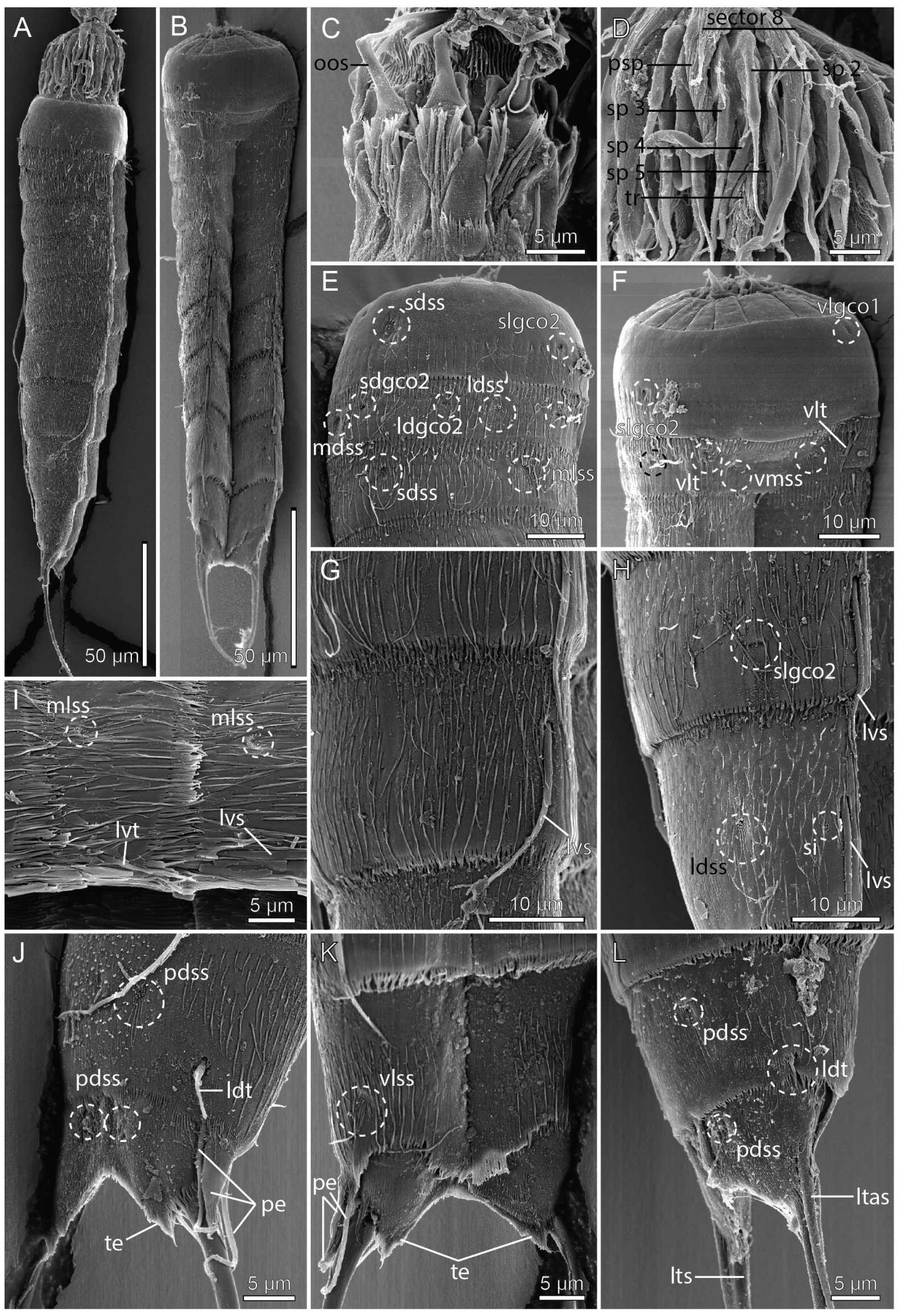


Table 7. Summary of nature and location of sensory spots, glandular cell outlets, tubes and spines arranged by series in Echinoderes hamiltonorum sp. nov. Abbreviations: LA = lateral accessory; LD = laterodorsal; $\mathrm{LV}=$ lateroventral; $\mathrm{MD}=$ middorsal; $\mathrm{ML}=$ midlateral; $\mathrm{PD}=$ paradorsal; $\mathrm{PV}=$ paraventral; $\mathrm{SD}=$ subdorsal; $\mathrm{SL}=$ sublateral; $\mathrm{VL}=$ ventrolateral; $\mathrm{VM}=$ ventromedial; $\mathrm{ac}=$ acicular spine; $\mathrm{gco} 1 / 2=$ glandular cell outlet type $1 / 2$; ltas = lateral terminal accessory spine; lts = lateral terminal spine; pe = penile spines; $\mathrm{si}=$ sieve plate; $\mathrm{ss}=$ sensory spot; $\mathrm{tu}=$ tube; $(+\mathrm{P})=$ female and $\left({ }^{\lambda}\right)=$ male conditions of sexually dimorphic characters; $*$ = character not present in all specimens.

\begin{tabular}{|c|c|c|c|c|c|c|c|c|c|c|c|}
\hline \multicolumn{12}{|c|}{ Position } \\
\hline Segment & MD & PD & SD & LD & ML & SL & LA & LV & VL & VM & PV \\
\hline 1 & gcol & & ss & ss* & & gco2 & & & gco1 & & \\
\hline 2 & gcol ,ss & & gco2 & ss, gco2 & & gco2 & & & tu & ss & \\
\hline 3 & gcol 1 & & ss & & ss & & & & & & gcol \\
\hline 4 & $\mathrm{ac}$ & gcol & & & & & & & & & gcol \\
\hline 5 & gcol & & & & ss & & & tu & & & gcol \\
\hline 6 & ac & ss, gco1 & & & ss & & & $\mathrm{ac}$ & & ss & gcol \\
\hline 7 & gco1 & ss & & & ss & & & ac & & ss & gcol \\
\hline 8 & $\mathrm{ac}$ & ss, gco1 & & & & gco2* & & ac & & & gcol \\
\hline 9 & & ss, gcol & & ss & & & si & $\mathrm{ac}$ & ss & & gcol \\
\hline 10 & gco1, gco1 & ss & & tu & & & & & ss & & gcol \\
\hline 11 & & ss & & & $x \operatorname{pe}\left({ }^{\lambda}\right)$ & & $1 \operatorname{tas}(P)$ & lts & & & \\
\hline
\end{tabular}

Segment 2 consists of a complete cuticular ring. Pachycyclus of the anterior segment margin is relatively thin and not interrupted. Tubes present in ventrolateral positions (Figs 7B, 8C, 9F), and very minute glandular cell outlets type 2 in subdorsal, laterodorsal and sublateral (Fig. 8F) positions (Figs 7A-B, $8 \mathrm{~B}-\mathrm{C}, 9 \mathrm{E}-\mathrm{F})$. Sensory spots are located in middorsal, laterodorsal and ventromedial positions (Figs 7AB, 9E-F). Glandular cell outlet type 1 present in middorsal position only, near anterior segment margin. Secondary pectinate fringe present near anterior segment margin of this and the following segments, but it is usually covered by the preceding segment. On this and the following eight segments, the cuticular hairs are bracteate. Fairly long hairs densely cover the segment. The posterior segment margin is nearly straight, terminating in a pectinate fringe with long and flexible fringe tips.

Segment 3, and remaining segments, consisting of one tergal and two sternal plates (Figs 7B, 8A, C, E, 9B). Pachycyclus of the anterior segment margin is thin and interrupted at the tergosternal junctions and middorsally. Sensory spots present in subdorsal and midlateral positions (Figs 7A, 9E), and glandular cell outlets type 1 in middorsal and paraventral positions. Posterior segment margin straight, terminating in pectinate fringe with long and flexible fringe tips. Cuticular hairs cover tergal plate, except in middorsal position, and lateral halves of sternal plates.

Segment 4 with acicular spine in middorsal position (Figs 7A, 8B). Sensory spots not present, but glandular cell outlets type 1 present in paradorsal (Fig. 8B) and paraventral positions. Pachycycli, pectinate fringe of posterior margin and cuticular hairs as on preceding segment.

Segment 5 with a pair of minute tubes in lateroventral positions (Figs 7B, 8B, 9I). Sensory spots present in midlateral positions (Fig. 9I), and glandular cell outlets type 1 in middorsal and paraventral positions. Pachycycli, pectinate fringe of posterior margin and cuticular hairs as on preceding segment.

Segment 6 with acicular spines in middorsal and lateroventral positions (Figs 7A-B, 8D-E, 9I). Sensory spots present in paradorsal (Fig. 8D), midlateral (Fig. 9I) and ventromedial positions, and glandular cell outlets type 1 in paradorsal (Fig. 8D) and paraventral positions. Pachycycli, pectinate fringe of posterior margin and cuticular hairs as on preceding segment. 
Segment 7 with acicular spines in lateroventral positions (Figs 7B, 8D-E). Sensory spots present in paradorsal (Fig. 8D), midlateral and ventromedial positions, and glandular cell outlets type 1 in middorsal (Fig. 8D) and paraventral positions. Pachycycli and pectinate fringe of posterior margin as on preceding segment; cuticular hair covering also as on preceding segment, but with middorsal hairless area being broader, posteriorly expanding into paradorsal and subdorsal areas as well.

Segment 8 with acicular spines in middorsal and lateroventral positions (Figs 7A-B, 8D-E, 9G-H). Some paratypes with fairly large sublateral glandular cell outlets type 2 (Figs 7B, 8G, 9H) present, but others (including the holotype) without such outlets (compare Fig. 8E vs 8G and Fig. 9H vs 9G); the outlets were present in eight females and one male, from stations 2, 3,6 and 8, and were missing in three females and four males, from stations 3, 5 and 6. Sensory spots present in paradorsal positions (Fig. 8D), and glandular cell outlets type 1 in paradorsal (Fig. 8D) and paraventral positions. Pachycycli, pectinate fringe of posterior margin and cuticular hairs as on preceding segment.

Segment 9 with acicular spines in lateroventral positions (Figs 7B, 8G, 9H). Sensory spots present in paradorsal, laterodorsal (Fig. 9H), and ventrolateral positions, and glandular cell outlets type 1 in paradorsal (Fig. 8D) and paraventral (Fig. 8E) positions. Small rounded sieve plates are present in lateral accessory positions (Figs 7B, 8E, G, 9H). Pachycycli and pectinate fringe of posterior margin as on preceding segment; cuticular hair covering also as on preceding segment, but with subdorsal to middorsal areas covered with short, filiform, hair-like extensions.

Segment 10 with laterodorsal tubes near posterior segment margin (Figs 7A, C, 9J, L); tubes are minute and do not show sexual dimorphism. Sensory spots present in paradorsal and ventrolateral positions (Fig. 9J-L). Glandular cell outlets type 1 present as two middorsal ones, and one pair in paraventral positions. The posterior segment margin of the tergal plate is straight, terminating in a pectinate fringe with rather short fringe tips. The margins of the sternal plates have slightly longer fringe tips, and extend midventrally into a broad comb that almost reaches the margin of the terminal segment (Fig. 9K). Pachycycli as on preceding segment; cuticular hair covering also as on preceding segment, but with short, filiform, hair-like extensions present in paradorsal to middorsal areas only.

Segment 11 with lateral terminal spines (Figs 7A-B, 8A, H, 9L). Males with three pairs of penile spines; dorsal and ventral penile spines are thin, flexible tubes, whereas the median ones are thicker, conical, and stout (Figs 7C-D, 9J-L); females with thin and relatively short lateral terminal accessory spines (Figs 7A-B, 8H, 9L). Sensory spots without marginal hairs present in paradorsal positions (Fig. 9J). Glandular cell outlets type 1 not observed. The segment is completely devoid of cuticular hairs, but densely covered with short, filiform hair-like extensions, in middorsal to laterodorsal areas, and in ventromedial to midventral areas. Tergal extensions are short, with oblique margins that end in a short lateral point; lateral tips with long, extended fringe tips that looks like setae (Figs 7, 8H, 9J-K). Sternal plates shorter than tergal ones, and without tips or extensions.

\section{Remarks}

Echinoderes hamiltonorum sp. nov. is the first species known to show intraspecific variation in the presence or absence of glandular cell outlets type 2 on segment 8 . During the initial work, specimens with and without outlets on segment 8 were actually kept separate and considered as two potentially different species. However, since all meristic data overlapped between the two morphotypes, and since all other cuticular characters, including sensory spots, appeared to occur consistently in all specimens (but note that one specimen lacked laterodorsal sensory spots on segment 1), it was finally concluded that all specimens were conspecific. This was also done in the light of recent observations on other Echinoderes where the occurrence of tubes displayed intraspecific variation (see Grzelak \& Sørensen in press; Sørensen 2018). However, until now this variation has seemed to be restricted to tubes only, and 
this is the first report of intraspecific variation in the occurrence of glandular cell outlets type 2 . It can obviously not be ruled out that the dimorphism is reflected in the molecular sequences as well, and that the two morphotypes represent two semi-cryptic, sympatric species, but for now it seems most correct to consider them as one species.

The new species has the second most common spine pattern, and shares the presence of middorsal spines on segments 4,6 and 8 combined with lateroventral spines on segments 6 to 9 with twenty additional species of Echinoderes. However, E. hamiltonorum sp. nov. is the only species with this spine pattern that also shows glandular cell outlets type 2 in subdorsal, laterodorsal and sublateral positions of segment 2 , and tubes in ventrolateral positions. The ventrolateral tubes are truly very hard to visualize in LM, but even if they are confused with glandular cell outlets type 2, there would still be no other species with this particular combination of characters.

Echinoderes hamiltonorum sp. nov. probably shows most resemblance to E. hakaiensis (see Herranz et al. 2018). Echinoderes hakaiensis is the only other species with the same spine pattern as E. hamiltonorum sp. nov. that also shows cuticular structures in subdorsal, laterodorsal, sublateral and ventrolateral positions on segment 2. Echinoderes hakaiensis has tubes though, instead of glandular cell outlets type 2, but these structures may sometimes be difficult to distinguish under LM. Echinoderes hakaiensis is also larger (the smallest $E$. hakaiensis has the same length as the largest $E$. hamiltonorum sp. nov.), and its tergal extensions appear conspicuously thicker, even though they are rather short. Echinoderes hakaiensis furthermore has lateral accessory tubes on segment 8, and even though they could be confused with the type 2 sublateral glandular cell outlets of E. hamiltonorum sp. nov., it is usually easier to see the actual tubes on segment 8, compared to tubes on other segments. Finally, E. hamiltonorum sp. nov. has its rather rare sublateral glandular cell outlets type 2 on segment 1 , and E. hakaiensis has no such structure.

In fact, the presence of glandular cell outlets type 2 on segment 1 in any Echinoderes was only reported very recently. The first report was on E. unispinosus (Yamasaki et al. 2018b, but see also Fig. 25C) and an undescribed species that was addressed in the same contribution (Yamasaki et al. 2018b). Both species have glandular cell outlets type 2 in midlateral positions on segment 1 . Outlets in these positions were also found during the present study in E. anniae sp. nov., and the only other known example of glandular cell outlets type 2 on segment 1 is from E. hamiltonorum sp. nov. However, unique for this species, the outlets are displaced to sublateral positions, rather than midlateral positions as found in the other species.

Echinoderes hviidarum sp. nov. urn:1sid:zoobank.org:act:58E8CD4B-12EA-49F0-8B97-167C2F5961B9

Figs 10-13, Tables 8-9

\section{Diagnosis}

Echinoderes with middorsal spines on segments 6 and 8, and spines in lateroventral positions on segments 6 to 9 . Tubes present in lateroventral positions on segment 5 , lateral accessory positions on segment 8 and laterodorsal positions on segments 9 and 10. Segment 11 with small, middorsal protuberance. Glandular cell outlets type 2 not present. Males with three pairs of penile spines; females with lateral terminal accessory spines.

\section{Etymology}

The first author (MVS) dedicates this species to Heidi Hviid and Thea Hviid, for always being there with helping hands and backup when the world kicks back. 


\section{Material examined}

\section{Holotype}

UNITED STATES OF AMERICA: adult ${ }^{7}$, US West Coast, off northern California, 39 $59^{\prime} 53^{\prime \prime} \mathrm{N}$, $125^{\circ} 26^{\prime} 36^{\prime \prime}$ W, St. 4, $2733 \mathrm{~m}$, collected from mud, mounted in Fluoromount G on a glass slide, 21 Sep. 2008 (NHMD -213610). See Fig. 1 for localities and Table 1 for detailed station data.

\section{Paratypes}

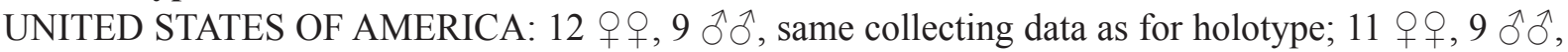

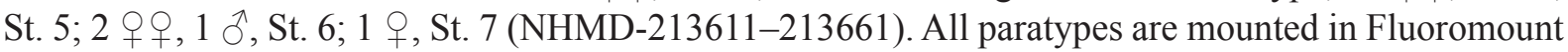
$\mathrm{G}$ on glass slides.

\section{Additional non-type material}

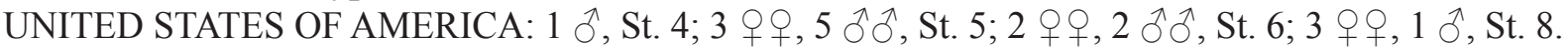
All specimens mounted for SEM and stored in the first author's personal reference collection.

\section{Description}

Adults with head, neck and eleven trunk segments (Figs 10A-B, 12A-B, 13A-B). The trunk appears stout in the anterior end, and turns more slender posteriorly. Segments 1 to 4 were often strongly contracted in fixed specimens. Lateral terminal spines long and slender, from $75 \%$ to slightly longer than trunk length (Fig 10C). For complete overview of measurements and dimensions, see Table 8. Distribution of cuticular structures, i.e., sensory spots, glandular cell outlets, spines and tubes, is summarized in Table 9.

The head consists of a retractable mouth cone and an introvert (Figs 11, 13C). Inner oral styles are present, but their exact number and arrangement could not be determined. The external mouth cone armature consists of nine outer oral styles, each with five basal fringe tips. The introvert sectors are defined by the ten primary spinoscalids in Ring 01 . Each primary spinoscalid consists of a basal sheath and a distal end piece with a blunt tip. The basal sheaths have marginal extensions forming two layers of transverse fringes. End pieces are smooth. Rings 02 and 04 have 10 spinoscalids and Ring 03 has 20 (Figs 11, 13C). All spinoscalids in these rings consist of a basal sheath and a pointed end piece. The basal sheaths terminate in fringed margins in spinoscalids of Rings 02 and 04, whereas the sheaths of Ring 03 have a median spike only. Ring 05 has 20 spinoscalids composed as those in the preceding ring, but with shorter end pieces. A ring of short fringes extends around the introvert in between spinoscalid Rings 04 and 05 . Rings 06 and 07 have only 6 spinoscalids each. These scalids are considerably shorter than preceding ones. Well-developed trichoscalids, attached to trichoscalid plates, are present in sectors 2, 4, 5, 7, 8 and 10. Described sector-wise, sectors 1 and 6 are similar, having spinoscalids arranged as two double diamonds. Sectors 2, 4, 8 and 10 all have spinoscalids arranged as a quincunx, located in between a medial anterior spinoscalid (Ring 02 ) and a trichoscalid plate. The remaining sectors, 3, 5, 7 and 9, are almost identical, having spinoscalids forming a set of double diamonds located anterior to a pair of Ring 07 spinoscalids. However, in sectors 5 and 7, one Ring 07 spinoscalid is missing, due to the presence of a trichoscalid plate that takes up space (Fig. 11).

The neck has 16 placids, measuring $12 \mu \mathrm{m}$ in length. The midventral placid is broadest, measuring $11 \mu \mathrm{m}$ in width at its base, whereas all others are narrower, measuring $7 \mu \mathrm{m}$ in width at their bases. The trichoscalid plates are well-developed and nearly triangular.

Segment 1 consists of a complete cuticular ring. Sensory spots are located on the anterior half of the segment, but not at the anterior margin, in subdorsal positions (Figs 10A, 13D); sensory spots are small and rounded. Glandular cell outlets type 1 present in middorsal (Fig. 13D) and sublateral positions. In most specimens the segment is completely devoid of cuticular hairs; however, a few specimens had a single transverse row with well-spaced hairs. The posterior segment margin is straight on the dorsal 

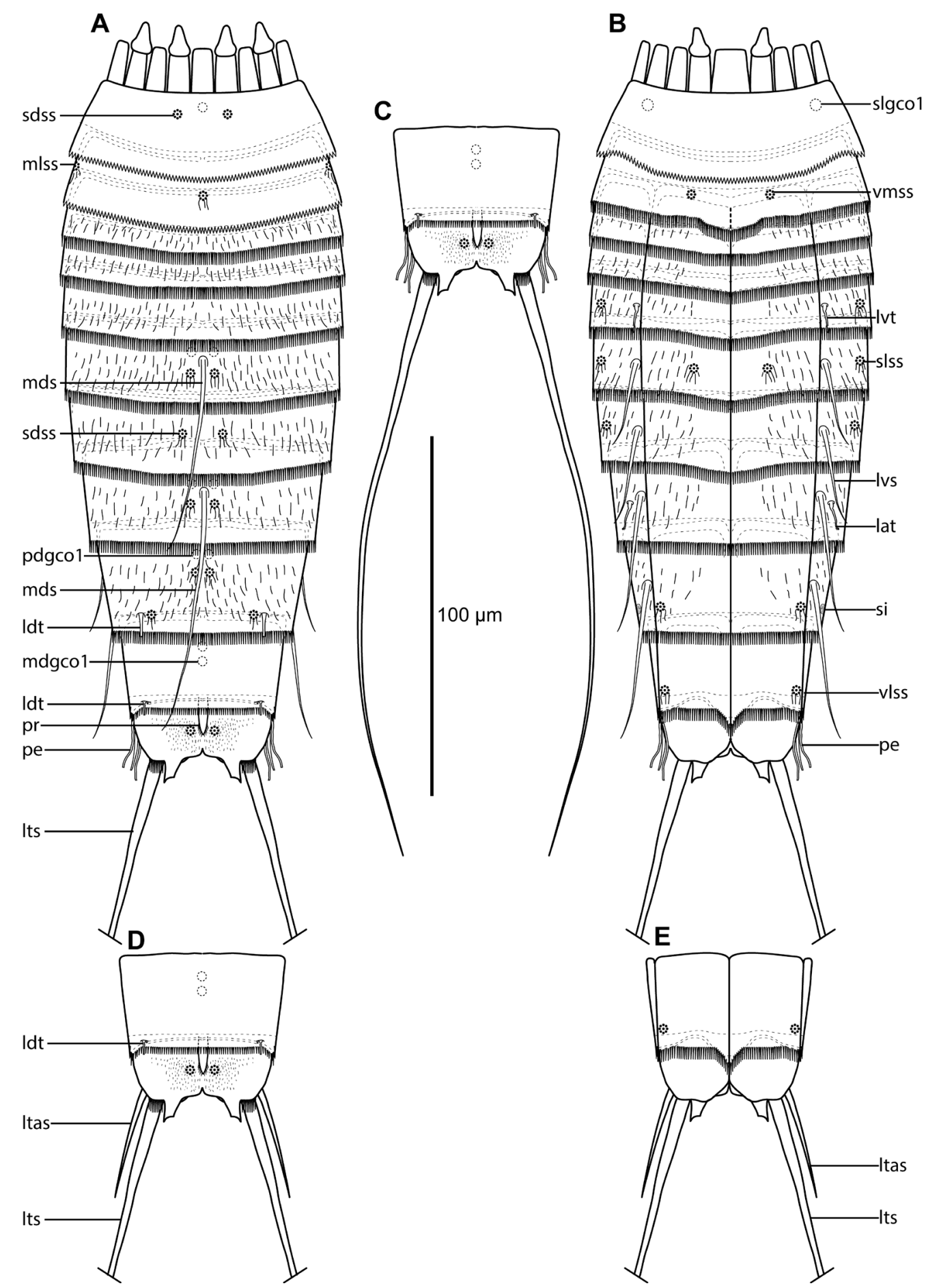

Fig. 10. Line art illustrations of Echinoderes hviidarum sp. nov. A. $\hat{\jmath}$, dorsal view. B. $\widehat{\jmath}$, ventral view. C. $\hat{O}$, segments 10 to 11 , with lateral terminal spines drawn in full length, dorsal view. D. $\odot$, segments 10 to 11 , dorsal view. E. + , segments 10 to 11, ventral view. Abbreviations: lat = lateral accessory tube; $1 \mathrm{dt}=$ laterodorsal tube; ltas = lateral terminal accessory spine; 1 ts = lateral terminal spine; lvs = lateroventral spine; lvt = lateroventral tube; $\mathrm{mdgco} 1=$ middorsal glandular cell outlet type $1 ; \mathrm{mds}=$ middorsal spine; mlss = midlateral sensory spot; pdgco $1=$ paradorsal glandular cell outlet type $1 ;$ pe = penile spines; $\mathrm{pr}=$ protuberance; sdss $=$ subdorsal sensory spot; $\mathrm{si}=$ sieve plate; slgcol $=$ sublateral glandular cell outlet type 1 ; slss = sublateral sensory spot; vlss = ventrolateral sensory spot; vmss = ventromedial sensory spot. 


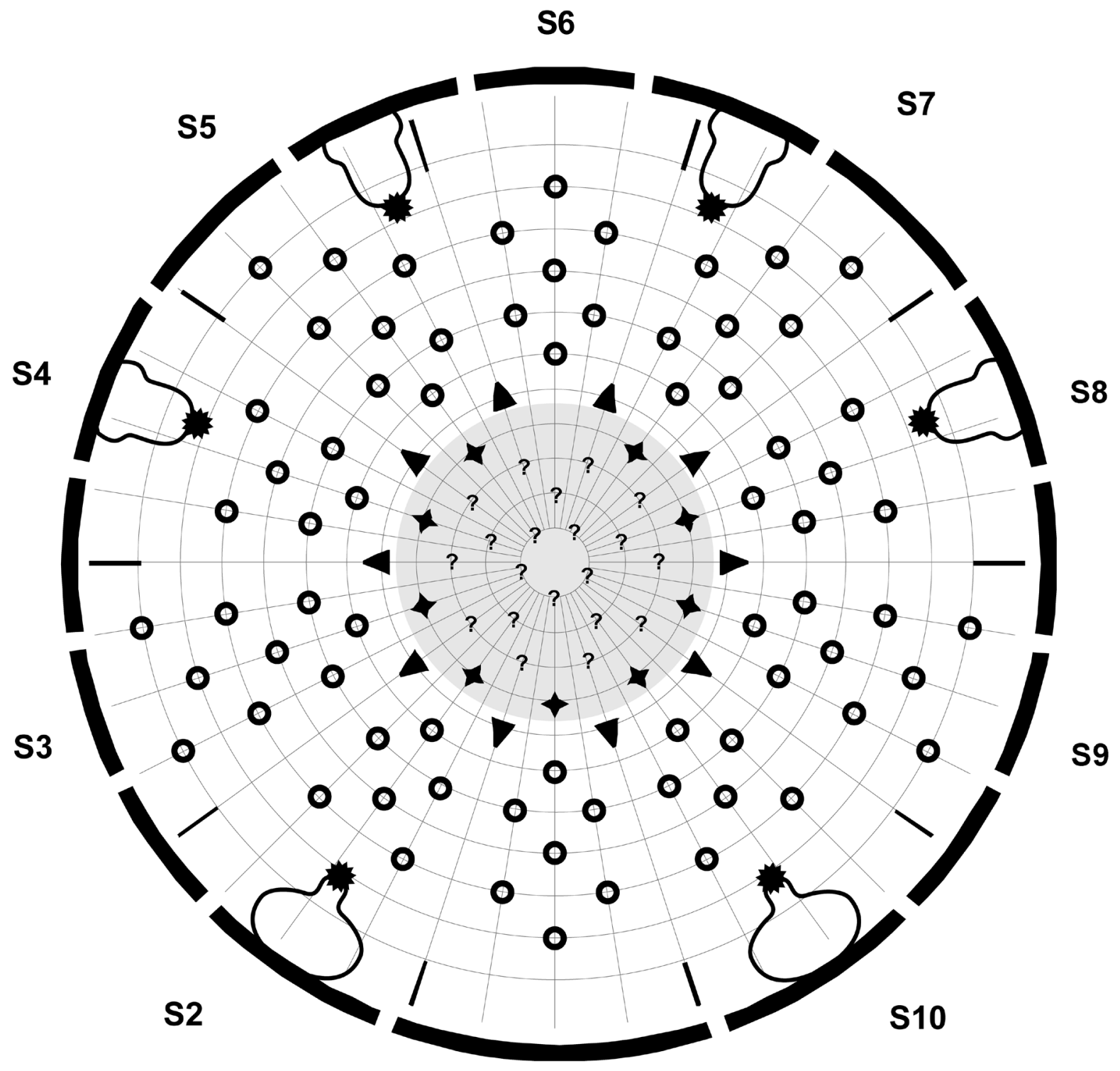

S1

Scalid and style arrangement

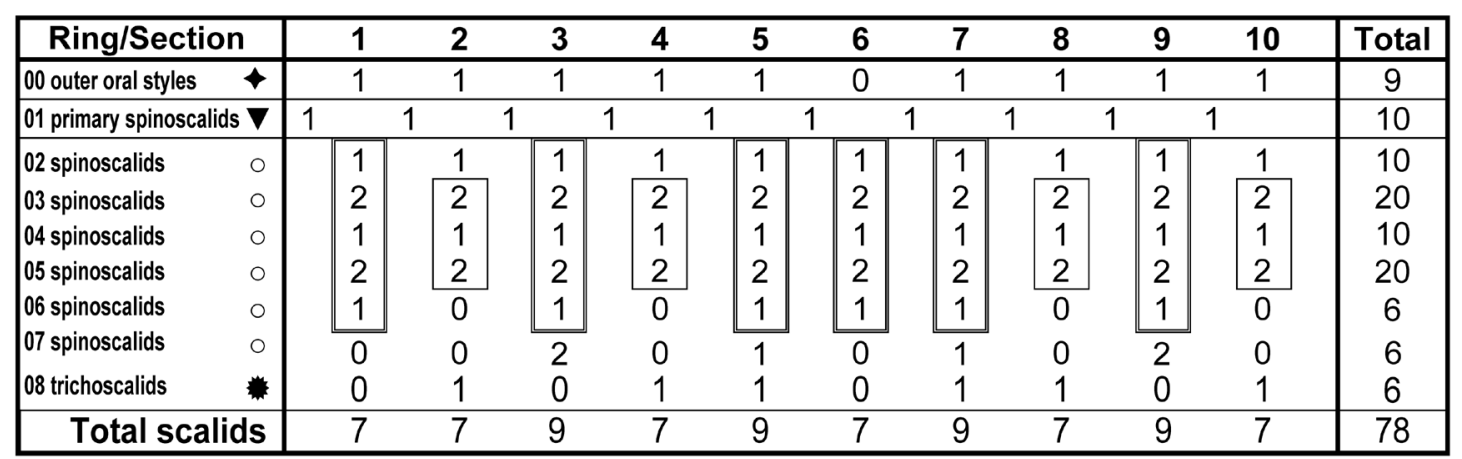

Fig. 11. Diagram of mouth cone (grey area), introvert and placids in Echinoderes hviidarum sp. nov., showing distribution of outer oral styles, scalids and trichoscalids. Table shows the scalid arrangement by sector; single-lined boxes mark quincunxes, double-lined boxes mark "double diamonds". 

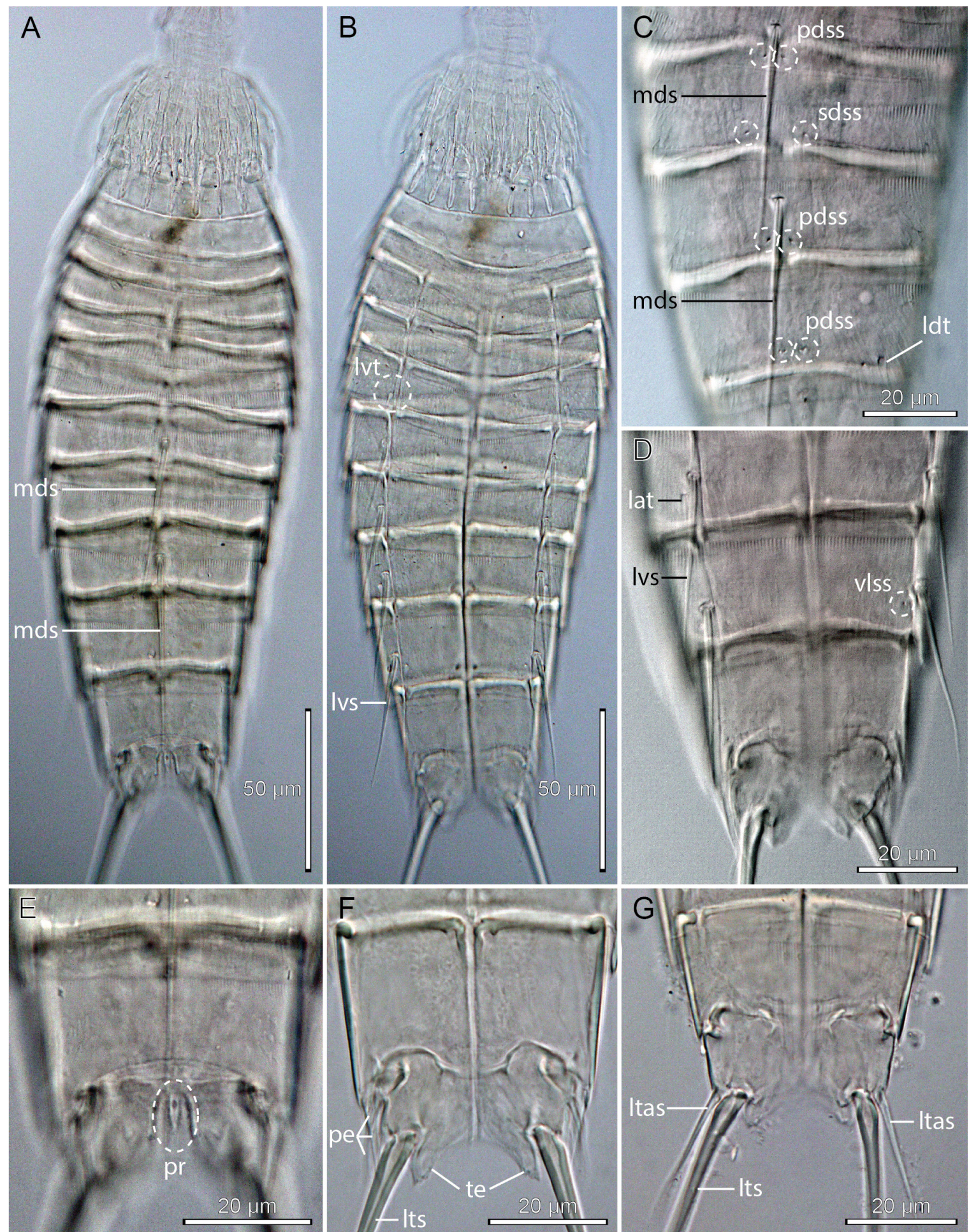

Fig. 12. Light micrographs showing overviews and details of Echinoderes hviidarum sp. nov., holotype, $\widehat{o}(\mathrm{~A}-\mathrm{B}, \mathrm{E}-\mathrm{F})(\mathrm{NHMD}-213610)$, paratype, $\widehat{\partial}$ (C-D) (NHMD-213614) and paratype, + (G) (NHMD213635). A. Dorsal overview. B. Ventral overview. C. Segments 6 to 9, dorsal view. D. Segments 8 to 11 , ventral view. E. $\widehat{\partial}$, segments 10 to 11 , dorsal view. F. $\hat{\jmath}$, segments 10 to 11 , ventral view. G. + , segments 10 to 11, ventral view. Abbreviations: lat = lateral accessory tube; ldt = laterodorsal tube; ltas = lateral terminal accessory spine; $1 \mathrm{ts}=$ lateral terminal spine; $1 \mathrm{vs}=$ lateroventral spine; $1 \mathrm{vt}=$ lateroventral tube; mds $=$ middorsal spine; pdss $=$ paradorsal sensory spot; $\mathrm{pe}=$ penile spines; $\mathrm{pr}=$ protuberance; sdss $=$ subdorsal sensory spot; te $=$ tergal extensions; vlss $=$ ventrolateral sensory spot. 
Table 8. Measurements from light microscopy of Echinoderes hviidarum sp. nov. (in $\mu \mathrm{m}$ ), including number of measured specimens (n) and standard deviation (SD). Abbreviations: (ac) = acicular spine; LTAS = lateral terminal accessory spine; LTS = lateral terminal spine; LV = lateroventral; $\mathrm{MD}=$ middorsal; MSW-5 = maximum sternal width, measured on segment 5 in this species; $\mathrm{S}=$ segment lengths; SW-10 = standard width, always measured on segment 10; TL = trunk length.

\begin{tabular}{ccccc}
\hline Character & n & Range & Mean & SD \\
\hline TL & 12 & $144-225$ & 177 & 22.97 \\
MSW-5 & 11 & $39-49$ & 45 & 3.61 \\
MSW-5/TL & 11 & $21.8-29.7 \%$ & $25.6 \%$ & $2.65 \%$ \\
SW-10 & 11 & $36-39$ & 37 & $1.29 \%$ \\
SW-10/TL & 11 & $16.4-25.7 \%$ & $21.4 \%$ & $2.65 \%$ \\
S1 & 12 & $16-24$ & 21 & 3.11 \\
S2 & 12 & $17-24$ & 20 & 1.88 \\
S3 & 12 & $21-25$ & 23 & 1.15 \\
S4 & 12 & $21-29$ & 24 & 2.19 \\
S5 & 12 & $24-30$ & 27 & 2.06 \\
S6 & 12 & $26-32$ & 28 & 2.57 \\
S7 & 12 & $26-34$ & 29 & 3.00 \\
S8 & 12 & $27-36$ & 32 & 3.03 \\
S9 & 12 & $31-26$ & 39 & 2.07 \\
S10 & 12 & $25-33$ & 29 & 3.06 \\
S11 & 12 & $22-27$ & 24 & 1.45 \\
MD6 (ac) & 12 & $27-54$ & 37 & 9.34 \\
MD8 (ac) & 10 & $48-66$ & 55 & 7.41 \\
LV6 (ac) & 11 & $17-28$ & 21 & 4.29 \\
LV7 (ac) & 10 & $20-30$ & 24 & 3.92 \\
LV8 (ac) & 11 & $22-42$ & 30 & 6.78 \\
LV9 (ac) & 12 & $28-45$ & 35 & 5.71 \\
LTS & 12 & $146-170$ & 159 & 7.65 \\
LTS/TL & 12 & $75.1-105.2 \%$ & $90.7 \%$ & $9.16 \%$ \\
LTAS & 5 & $24-29$ & 27 & 1.79 \\
\hline & & & &
\end{tabular}

and ventral sides, but with sublateral concave indentations, terminating in a pectinate fringe with short, triangular saw-tooth tips.

Segment 2 consists of a complete cuticular ring. Pachycyclus of the anterior segment margin is relatively thin, middorsally interrupted. Sensory spots are located in middorsal (Fig. 13D), midlateral and ventromedial positions (Fig. 10A-B). Sensory spots very minute, but with rather long, thin marginal cuticular hairs; all sensory spots from this segment to segment 10 have the same appearance. Glandular cell outlets type 1 not observed. Secondary pectinate fringe present near anterior segment margin of this and the following segments, but it is usually covered by the preceding segment. The segment has very few or no hairs at all. On this and all following segments, the cuticular hairs are bracteate (when present). The posterior segment margin is nearly straight, but with a rounded midventral extension; dorsally it terminates in a pectinate fringe with saw-tooth fringe tips as on preceding segment, whereas fringe tips on the lateral and ventral sides are long and slender.

Segment 3, and remaining segments, consist of one tergal and two sternal plates (Figs 10A-B, 12B). Pachycyclus of the anterior segment margin of medium thickness, interrupted at the tergosternal junctions and middorsally. No conspicuous cuticular structures present. Fairly long hairs are arranged in two to 
Table 9. Summary of nature and location of sensory spots, glandular cell outlets, tubes and spines arranged by series in Echinoderes hviidarum sp. nov. Abbreviations: LA = lateral accessory; LD = laterodorsal; $\mathrm{LV}=$ lateroventral; $\mathrm{MD}=$ middorsal; $\mathrm{ML}=$ midlateral; $\mathrm{PD}=$ paradorsal; $\mathrm{SD}=$ subdorsal; $\mathrm{SL}=$ sublateral; $\mathrm{VL}=$ ventrolateral; $\mathrm{VM}=$ ventromedial; $\mathrm{ac}=$ acicular spine; gco1 = glandular cell outlet type 1 ; ltas = lateral terminal accessory spine; lts = lateral terminal spine; $\mathrm{pe}=$ penile spines; $\mathrm{pr}=$ protuberance; $\mathrm{si}=$ sieve plate; $\mathrm{ss}=$ sensory spot; $\mathrm{tu}=$ tube; $(\stackrel{+}{+})=$ female and $(\widehat{\delta})=$ male conditions of sexually dimorphic characters.

\begin{tabular}{|c|c|c|c|c|c|c|c|c|c|c|}
\hline \multicolumn{11}{|c|}{ Position } \\
\hline Segment & MD & PD & SD & LD & ML & SL & LA & LV & VL & VM \\
\hline 1 & gcol & & ss & & & gcol & & & & \\
\hline 2 & ss & & & & SS & & & & & ss \\
\hline 3 & & & & & & & & & & \\
\hline 4 & & & & & & & & & & \\
\hline 5 & & & & & & ss & & tu & & \\
\hline 6 & $\mathrm{ac}$ & ss, gcol & & & & ss & & ac & & ss \\
\hline 7 & & & ss & & & ss & & $\mathrm{ac}$ & & \\
\hline 8 & $\mathrm{ac}$ & ss, gcol & & & & & tu & $\mathrm{ac}$ & & \\
\hline 9 & & ss, gcol & & ss, tu & & si & & $\mathrm{ac}$ & ss & \\
\hline 10 & gco, gco1 & & & tu & & & & & ss & \\
\hline 11 & $\mathrm{pr}$ & ss & & & $3 \times \operatorname{pe}\left(0^{\lambda}\right)$ & & $\operatorname{ltas}(P)$ & lts & & \\
\hline
\end{tabular}

three rows across the dorsal and lateral side, to the ventromedial positions of the ventral side. Posterior segment margin straight, terminating in pectinate fringe with long and slender fringe tips. Cuticular hairs distributed over tergal plate and lateral halves of sternal plates.

Segment 4 as segment 3 .

Segment 5 with minute tubes in lateroventral positions (Figs 10B, 12B). Sensory spots present in sublateral positions. Glandular cell outlets type 1 not observed. Pachycycli, pectinate fringe of posterior margin and cuticular hairs as on preceding segment.

Segment 6 with acicular spines in middorsal and lateroventral positions (Figs 10A-B, 12A-C, 13A). Sensory spots present in paradorsal (Fig. 12C), sublateral and ventromedial positions (Fig. 10A-B).

Fig. 13 (opposite page). Scanning electron micrographs showing overviews and details of Echinoderes hviidarum sp. nov. A. Dorsal overview. B. Ventral overview. C. Introvert sector 6 (middorsal). D. Segments 1 to 3, dorsal view. E. Detail showing attachment of lateroventral spine and lateral accessory tube on segment 8 . F. Detail showing the typical stout laterodorsal tube on segment 9 . G. Detail showing laterodorsal tube on segment 10 , with associated papillary structure. H. $q$, segments 10 to 11, ventral view. I. Detail showing the less common slender laterodorsal tube on segment 9 . J. $\hat{\varnothing}$, segments 10 to 11 , dorsal view. K. $q$, segments 10 to 11, dorsal view. Abbreviations: lat $=$ lateral accessory tube; $1 \mathrm{dss}=$ laterodorsal sensory spot; $1 \mathrm{dt}=$ laterodorsal tube; 1 tas = lateral terminal accessory spine; lts = lateral terminal spine; lvs = lateroventral spine; mdgco 1 = middorsal glandular cell outlet type $1 ;$ mdp = middorsal placid mds = middorsal spine; mdss = middorsal sensory spot; pap = papillary structure; $\mathrm{pe}=$ penile spines; $\mathrm{pr}=$ protuberance; $\mathrm{psp}=$ primary spinoscalid; sdss = subdorsal sensory spot; $\mathrm{sp}=$ spinoscalid followed by introvert ring number; te $=$ tergal extensions; $\operatorname{tr}=$ trichoscalid; vlss $=$ ventrolateral sensory spot. 
SØRENSEN M.V. et al., Deep-sea Echinoderidae from the Northwest Pacific

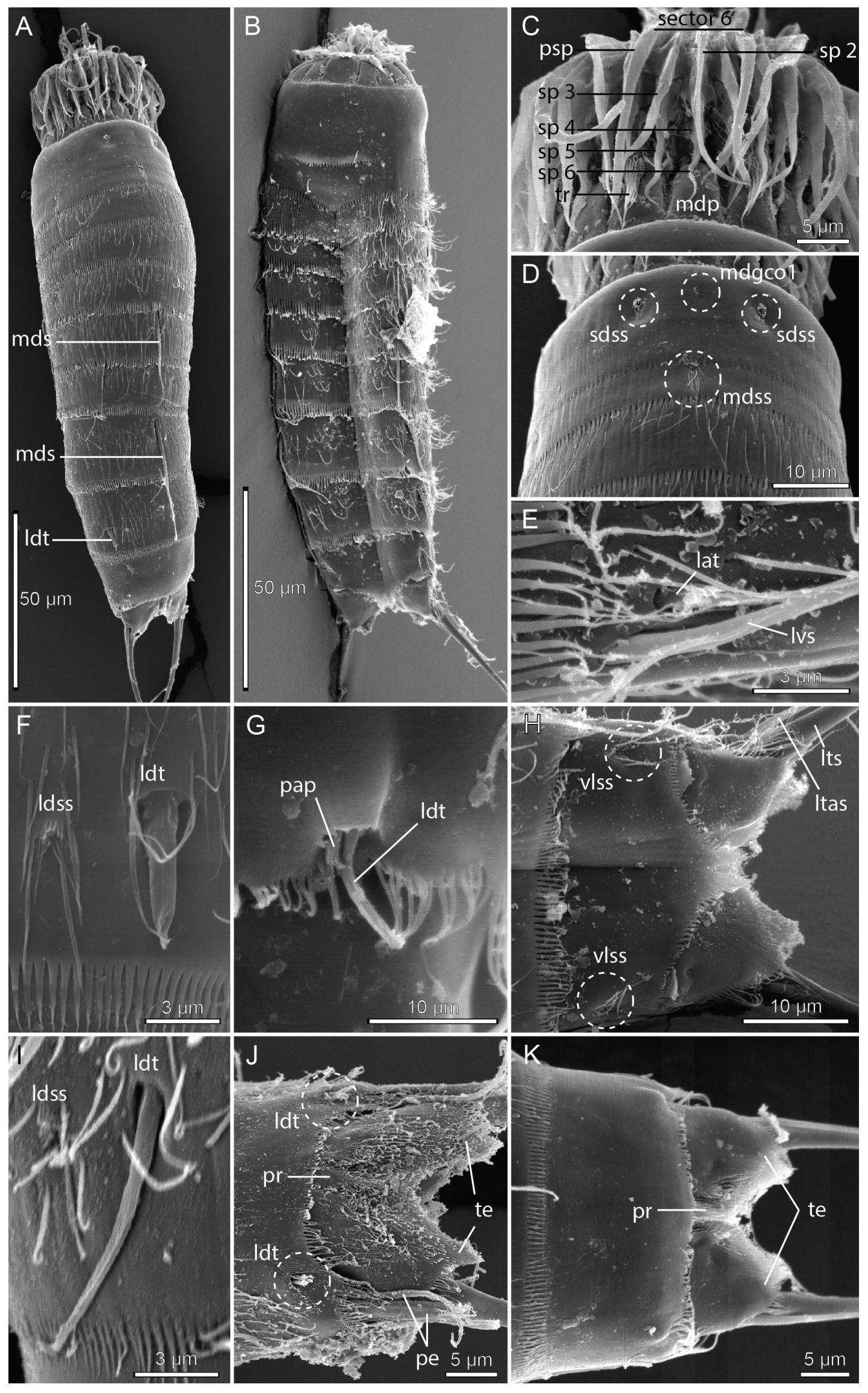


Glandular cell outlets type 1 only observed in paradorsal positions. Pachycycli, pectinate fringe of posterior margin and cuticular hairs as on preceding segment.

Segment 7 with acicular spines in lateroventral positions (Figs 10B, 12B). Sensory spots present in subdorsal (Fig. 12C) and sublateral positions (Fig. 10A-B). Glandular cell outlets type 1 not observed. Pachycycli, pectinate fringe of posterior margin and cuticular hairs as on preceding segment.

Segment 8 with acicular spines in middorsal and lateroventral positions (Figs 10A-B, 12A-D, 13A). Minute tubes present in lateral accessory positions (Figs 10B, 12D, 13E). Middorsal spine is usually long, reaching the terminal segment (Figs 10A, 12A). Sensory spots and glandular cell outlets type 1 present in paradorsal positions only (Figs 10A, 12C). Pachycycli, pectinate fringe of posterior margin and cuticular hairs as on preceding segment.

Segment 9 with acicular spines in lateroventral positions (Figs 10B, 12B, D). Tubes present in laterodorsal positions (Figs 10A, 12C, 13A, F, I); in most specimens (including the holotype) the tubes are short and stout (Fig. 13F), without differentiated bases or lateral wings, but a few specimens showed longer and more slender tubes, but still without bases or wings (Fig. 13I). The dimorphism is not related to gender or locality. Sensory spots present in paradorsal (Fig. 12C), laterodorsal (Fig. 13F, I) and ventrolateral (Fig. 12D) positions, and glandular cell outlets type 1 in paradorsal positions. Small rounded sieve plates are present in sublateral positions (Fig. 10B). Pachycycli, pectinate fringe of posterior margin and cuticular hairs as on preceding segment.

Segment 10 with laterodorsal tubes near posterior segment margin (Figs 10A, D, 13G, J); tubes are very minute and sometimes appear to have an even shorter, protruding papillary structure located next to them (Fig. 13G), but due to their minute size, their presence was often hard to confirm. Sensory spots present in ventrolateral positions (Figs 10B, E, 13H). Glandular cell outlets type 1 present as two middorsal ones; other glandular cell outlets type 1 not observed. Segment almost devoid of hairs (Fig. 13H, K), except for a few short ones on the lateral sides. The posterior segment margin of the tergal plate is straight, with rather shorter fringe tips than those on the tergal plate. The margins of the sternal plates have considerably longer fringe tips and extend midventrally to a point that almost reaches the posterior margin of the terminal segment (Fig. 13H). Pachycycli as on preceding segment.

Segment 11 with lateral terminal spines (Fig. 10A-C). Males with three pairs of penile spines (Figs 10A$\mathrm{B}, 12 \mathrm{~F}, 13 \mathrm{~J})$; dorsal and ventral penile spines are thin, flexible tubes, whereas the median ones are thicker, conical, and stout; females with short lateral terminal accessory spines (Figs 10D-E, 12G, 13H). Sensory spots without long marginal hairs present in paradorsal positions. Glandular cell outlets type 1 not observed. A short middorsal protuberance extends from the intersegmentary joint (Figs 10A, D, $12 \mathrm{E}, 13 \mathrm{~J}-\mathrm{K})$. The segment is completely devoid of cuticular hairs, but densely covered with short hairlike extensions, in middorsal to laterodorsal areas. Tergal extensions are short and pointed, with an extra tooth at the inferior margin (Figs 10, 12F, 13J-K).

\section{Remarks}

The spine and tube distribution in the lateral series of E. hviidarum sp. nov., with tubes in lateroventral positions of segment 5 and in lateral accessory positions of segment 8 , and spines in lateroventral positions of segments 6 to 9, is quite common among species of Echinoderes and is shared with 21 congeners. However, the species is very easily recognized by the presence of middorsal spines on segments 6 and 8 only. This trait is shared exclusively with E. daenerysae Grzelak \& Sørensen, 2017. Furthermore, it has laterodorsal tubes on segment 9, which is otherwise found only in E. belenae Pardos, Herranz \& Sánchez, 2016 and E. daenerysae (Pardos et al. 2016b; Grzelak \& Sørensen 2018). However, $E$. belenae cannot in any way be confused with E. hviidarum sp. nov. The species has conspicuously 
short and stout lateral terminal spines, middorsal spines on segments 4,6 , and 8 , and numerous tubes in various positions (Pardos et al. 2016b). Echinoderes daenerysae shows a much closer resemblance with E. hviidarum sp. nov., in terms of spine/tube distribution as well as general appearance, and we would consider the two species to be putatively closely related. They can be distinguished, though, by the presence of laterodorsal and ventrolateral tubes (ventrolateral not present in all specimens though) on segment 2 in E. daenerysae, and by the presence of a middorsal protuberance between segments 10 and 11 in E. hviidarum sp. nov. It should be stressed that the laterodorsal tubes on segment 9 are extremely difficult to visualize with LM; hence, the easiest and safest way to identify the species is by its dorsal spine pattern, combined with the absence of tubes on segment 2.

Echinoderes juliae sp. nov. urn:1sid:zoobank.org:act:3235E6EC-DA74-4269-8251-28654AA0EE69

Figs 14-17, Tables 10-11

\section{Diagnosis}

Echinoderes with middorsal spines on segments 4 to 8, and spines in lateroventral positions on segments 6 to 9 . Tubes present in lateroventral positions on segment 5. Glandular cell outlets type 2 present in subdorsal, laterodorsal, sublateral and ventrolateral positions on segment 2, in sublateral positions on segments 3, 4 and 8, and in midlateral positions on segment 5. Segment 11 with small, middorsal protuberance. At least posterior half of tergal plate of segment 11 divided by longitudinal fissure. Males with three pairs of penile spines; females with long lateral terminal accessory spines.

\section{Etymology}

The first author (MVS) dedicates this species to his friend and former meiofauna colleague Julia Zekely.

\section{Material examined}

Holotype

UNITED STATES OF AMERICA: adult + , US West Coast, California, off Monterey, 36 $40^{\prime} 52^{\prime \prime} \mathrm{N}$, $122^{\circ} 49^{\prime} 37^{\prime \prime}$ W, St. 6, $2719 \mathrm{~m}$ deep, collected from mud, mounted in Fluoromount $\mathrm{G}$ on a glass slide, 24 Sep. 2008 (NHMD-213666). See Fig. 1 for localities and Table 1 for detailed station data.

\section{Paratypes}

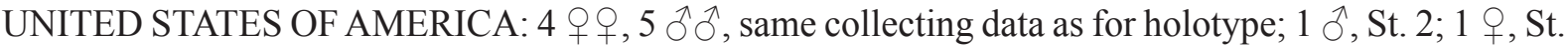

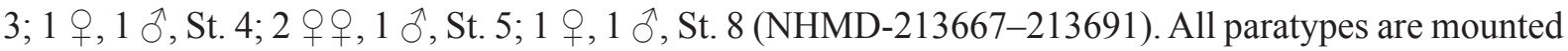
in Fluoromount G, one on H-S slide and the remaining on glass slides.

\section{Additional non-type material}

UNITED STATES OF AMERICA: $4 \uparrow q, 2 \hat{\jmath}$, same collecting data as for holotype, mounted for SEM and stored in the first author's personal reference collection.

\section{Description}

Adults with head, neck and eleven trunk segments (Figs 14A-B, 15, 17A-B). The trunk appears slender, with nearly parallel-sided segments in the anterior end, and slightly tapering trunk from segment 8 (Fig. 15A-B). Lateral terminal spines long and slender, around $75 \%$ of trunk length, and lateral terminal accessory spines in females long as well, around $60 \%$ of lateral terminal spine length (Fig. 14A-C). For complete overview of measurements and dimensions, see Table 10. Distribution of cuticular structures, i.e., sensory spots, glandular cell outlets, spines and tubes, is summarized in Table 11. 
All specimens had their heads completely retracted; hence, no details on head morphology can be provided. The neck has 16 placids, measuring $14 \mu \mathrm{m}$ in length. The midventral placid is broadest, measuring $12 \mu \mathrm{m}$ in width at its base, whereas all others are narrower, measuring $8 \mu \mathrm{m}$ in width at their bases. Four dorsal and two ventral trichoscalid plates are present, with the two dorsal pairs being somewhat triangular, whereas the ventral pair is more rounded.

Segment 1 consists of a complete cuticular ring. Sensory spots are located near the anterior margin in subdorsal and laterodorsal positions (Figs 14A, 16A, C); sensory spots are small and rounded, and lined with cuticular hairs. Glandular cell outlets type 1 present in middorsal and sublateral positions. Dorsal and lateral sides have scattered cuticular hairs, whereas the ventral side is devoid of hairs except for a single line on the posterior part of the segment. The posterior segment margin is nearly straight, terminating in a pectinate fringe with relatively short and pointed fringe tips.

Segment 2 consists of a complete cuticular ring. Pachycyclus of the anterior segment margin is relatively thin and not interrupted. Glandular cell outlets type 2 are present in subdorsal, laterodorsal, sublateral and ventrolateral positions (Figs 14A-B, 15, 16A-C, 17C-D). Sensory spots are located in middorsal (Fig. 17C), laterodorsal, midlateral and ventromedial (Fig. 17D) positions. Sensory spots are extremely minute, consisting of one or two pores and a few papillae (see Fig. 17C inset), but with rather long, thin marginal cuticular hairs; all sensory spots from this segment and to segment 10 have this appearance. Glandular cell outlet type 1 present in middorsal position. Secondary pectinate fringe present near anterior segment margin of this and the following segments, but it is usually covered by the preceding segment. On this and the eight following segments, the cuticular hairs are bracteate and fairly long, but not that dense, covering the dorsal and lateral parts of the segment. Posterior segment margin as on preceding segment.

Segment 3, and remaining segments, consist of one tergal and two sternal plates (Figs 14B, 15B, 16B, E, H). Pachycyclus of the anterior segment margin is well-developed, and interrupted at the tergosternal and midsternal junctions and middorsally. Glandular cell outlets type 2 present in sublateral positions (Figs 14B, 15C, 16C, 17F), sensory spots in subdorsal positions and glandular cell outlets type 1 in middorsal (Fig. 16C) and ventromedial (Fig. 16B) positions. Posterior segment margin nearly straight, with fringe tips being slightly longer that those on preceding segment. Cuticular hairs cover the tergal plate and the lateral halves of the sternal plates.

Segment 4 with middorsal acicular spine (Figs 14A, 16A) and glandular cell outlets type 2 present in sublateral positions (Figs 14B, 15B, 16C, 17F-G). Sensory spots absent. Glandular cell outlets type 1 present in paradorsal (Fig. 16C) and ventromedial positions. Cuticular hairs basically as on preceding segment, except for the middorsal and paradorsal areas that are left hairless. Pachycycli and pectinate fringe of posterior margin as on preceding segment.

Segment 5 with middorsal acicular spine (Figs 14A, 16D), minute tubes in lateroventral positions (Figs 14B, 16E, 17E, G), and glandular cell outlets type 2 present in midlateral positions (Figs 14A-B, 15C, 16C, 17G). Sensory spots present in subdorsal (Fig. 16D) and ventromedial (Fig. 17E) positions. Glandular cell outlets type 1, pachycycli, pectinate fringe of posterior margin, and cuticular hairs as on preceding segment.

Segment 6 with acicular spines in middorsal and lateroventral positions (Figs 14A-B, 16D-E, 17E, G). Sensory spots present in paradorsal, subdorsal (Fig. 16D), midlateral and ventromedial (Figs 16E, 17E) positions. Glandular cell outlets type 1, pachycycli, pectinate fringe of posterior margin and cuticular hairs as on preceding segment. 

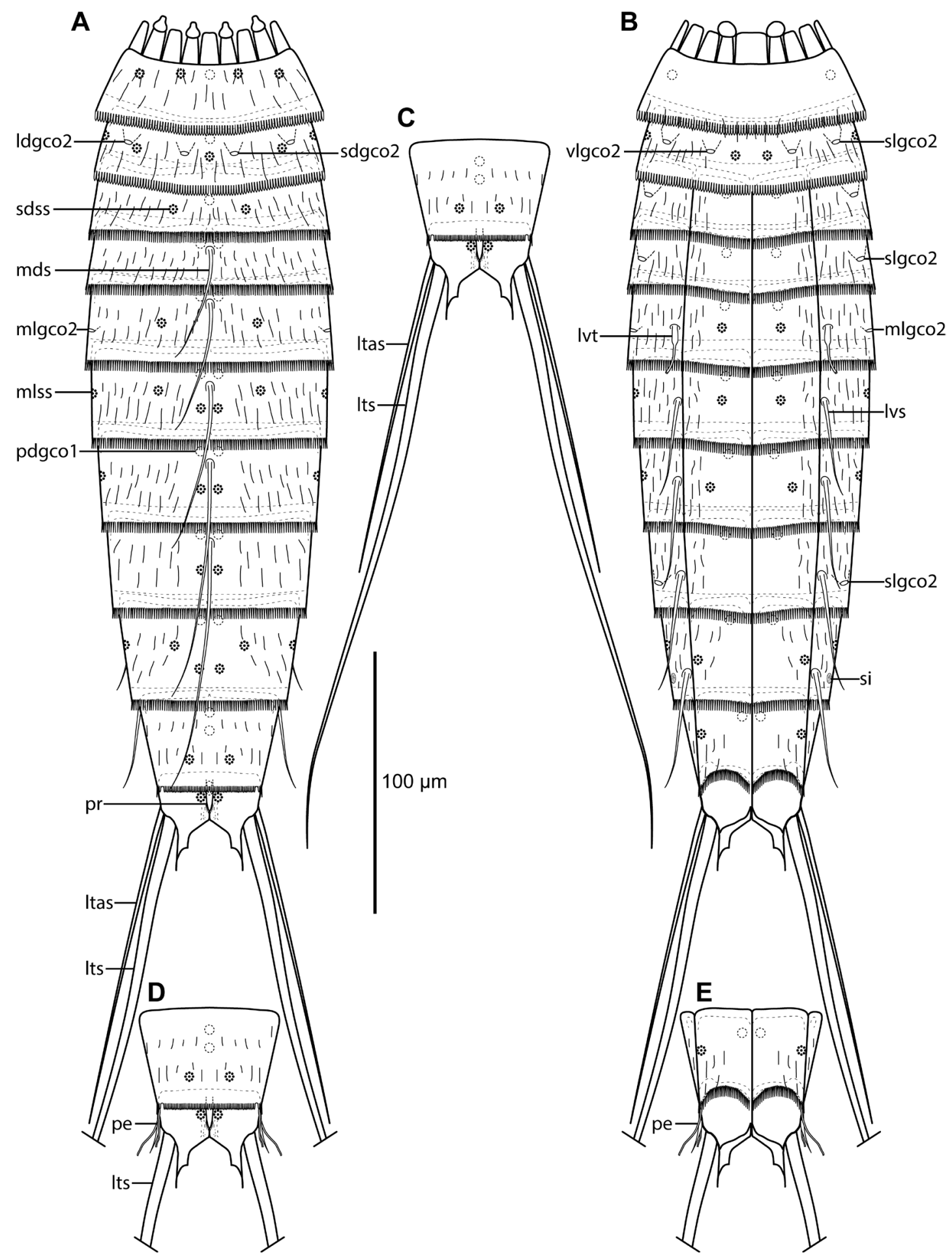

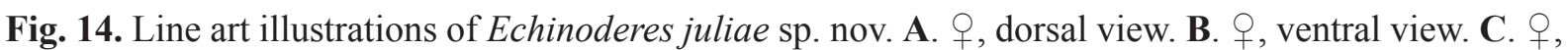

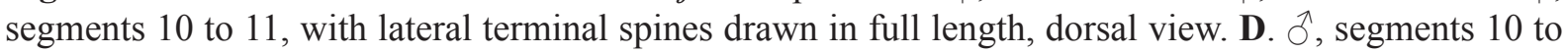
11 , dorsal view. E. ${ }^{\lambda}$, segments 10 to 11 , ventral view. Abbreviations: ldgco $2=$ laterodorsal glandular cell outlet type 2 ; ltas = lateral terminal accessory spine; lts = lateral terminal spine; lvs = lateroventral spine; $1 \mathrm{vt}=$ lateroventral tube; $\mathrm{mds}=$ middorsal spine; $\mathrm{mlgco} 2=$ midlateral glandular cell outlet type 2 ; mlss = midlateral sensory spot; pdgco $1=$ paradorsal glandular cell outlet type $1 ; \mathrm{pe}=$ penile spines; $\mathrm{pr}=$ protuberance; $\operatorname{sdgco} 2=$ subdorsal glandular cell outlet type 2 ; $\mathrm{sdss}=$ subdorsal sensory spot; $\mathrm{si}=$ sieve plate; $\operatorname{slgco} 2=$ sublateral glandular cell outlet type $2 ; \operatorname{vlgco} 2=$ ventrolateral glandular cell outlet type 2 . 

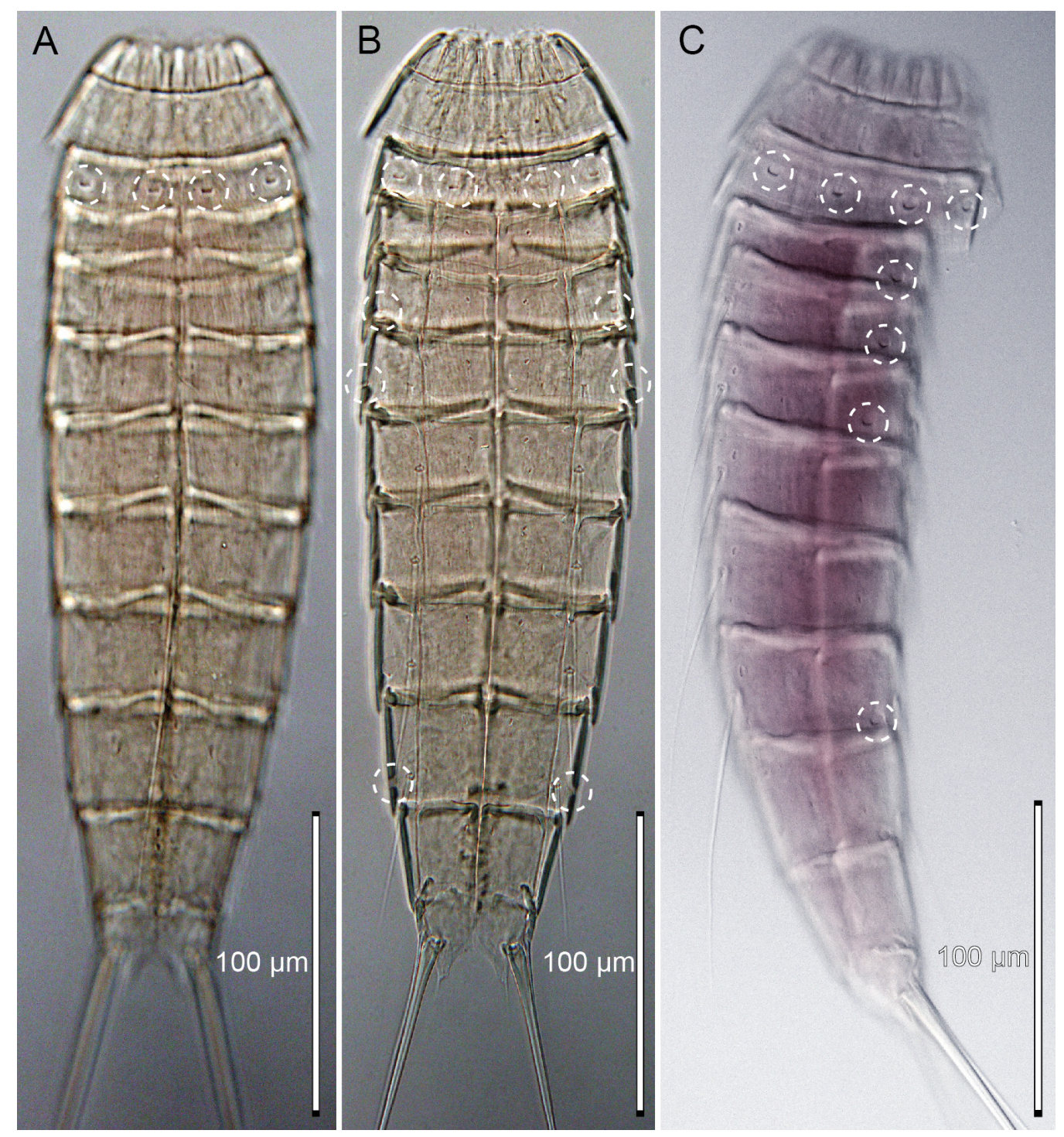

Fig. 15. Light micrographs showing overviews of Echinoderes juliae sp. nov., holotype, $q$ (A-B) (NHMD-213666) and paratype, ㅇ (C) (NHMD-213689). A. Dorsal overview. B. Ventral overview. C. Lateral view. Glandular cell outlets type 2 are marked with dashed white circles.

Fig. 16 (opposite page). Light micrographs showing overviews and details of Echinoderes juliae sp. nov., holotype, + (A-B, D-E, G-H) (NHMD-213666), paratype, ㅇ (C) (NHMD-213689), paratype, ô (F) (NHMD-213686) and paratype, o (I) (NHMD-213684). A. Segments 1 to 5, dorsal view. B. Segments 1 to 5, ventral view. C. Segments 1 to 6, lateral view. D. Segments 5 to 7, dorsal view. E. Segments 5 to 7 , ventral view. F. 0 , segments 10 to 11 , ventral view. G. Segments 8 to 10 , dorsal view. H. Segments 8 to 10 , ventral view. I. + , segments 10 to 11 , ventral view. Abbreviations: ldgco $2=$ laterodorsal glandular cell outlet type 2; ldss = laterodorsal sensory spot; 1 tas = lateral terminal accessory spine; 1 ts = lateral terminal spine; lvs = lateroventral spine; $1 \mathrm{vt}=$ lateroventral tube; $\operatorname{mdgco} 1=$ middorsal glandular cell outlet type 1 ; mds $=$ middorsal spine; $\mathrm{mlgco} 2=$ midlateral glandular cell outlet type $2 ;$ pdgco $1=$ paradorsal glandular cell outlet type $1 ;$ pdss = paradorsal sensory spot; $\mathrm{pe}=$ penile spines; pvgco $1=$ paraventral glandular cell outlet type 1; sdgco $2=$ subdorsal glandular cell outlet type 2 ; sdss $=$ subdorsal sensory spot; slgco $2=$ sublateral glandular cell outlet type 2 ; te $=$ tergal extensions; vlgco $2=$ ventrolateral glandular cell outlet type 2 ; vlss = ventrolateral sensory spot; vmgco $1=$ ventromedial glandular cell outlet type 1 ; vmss = ventromedial sensory spot. 

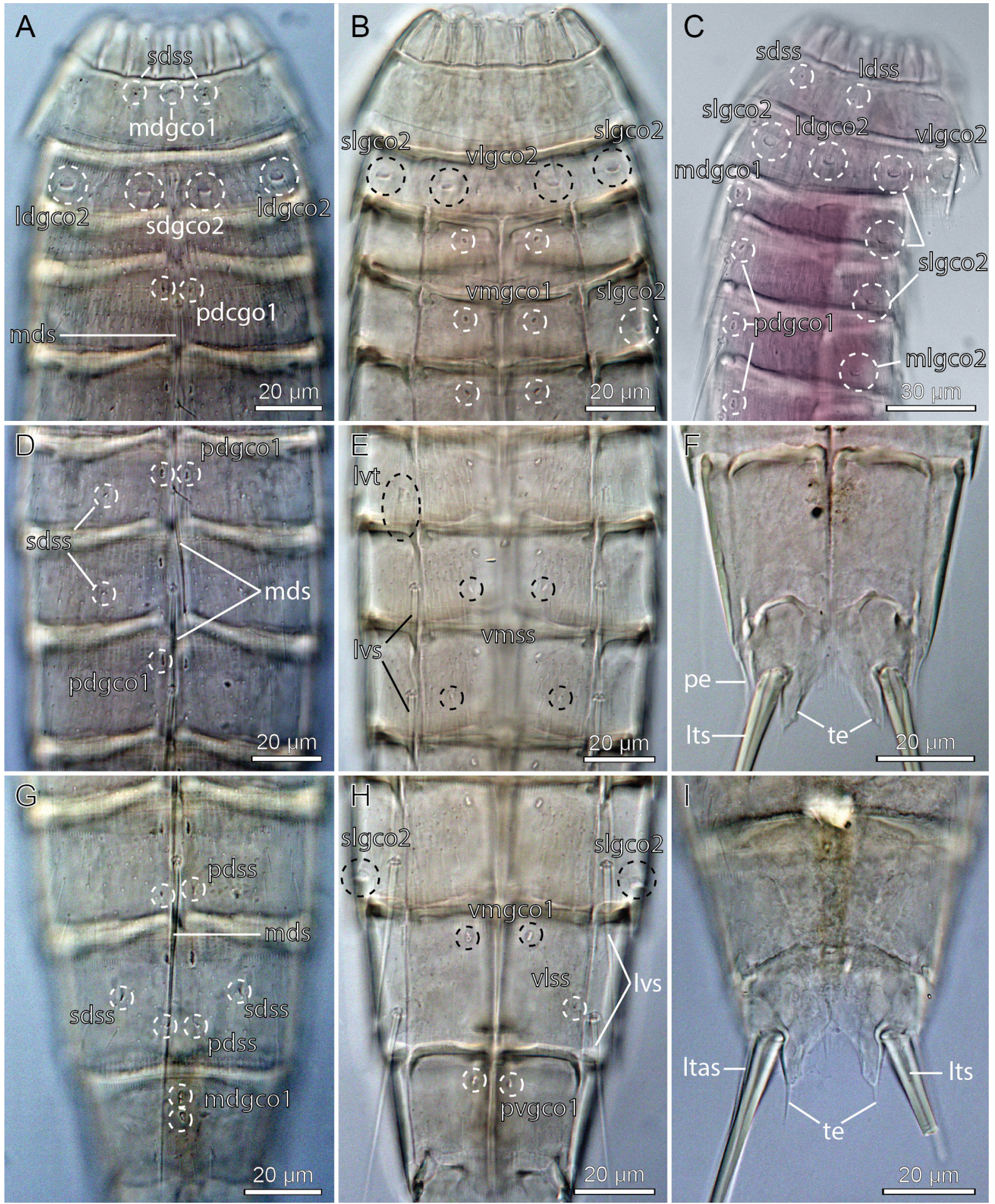
Table 10. Measurements from light microscopy of Echinoderes juliae sp. nov. (in $\mu \mathrm{m}$ ), including number of measured specimens (n) and standard deviation (SD). Abbreviations: $(\mathrm{ac})=$ acicular spine; LTAS $=$ lateral terminal accessory spine; LTS = lateral terminal spine; LV = lateroventral; $\mathrm{MD}$, middorsal; MSW-7 = maximum sternal width, measured on segment 7 in this species; $\mathrm{S}=$ segment lengths; SW$10=$ standard width, always measured on segment $10 ; \mathrm{TL}=$ trunk length.

\begin{tabular}{ccccc}
\hline Character & n & Range & Mean & SD \\
\hline TL & 10 & $285-327$ & 305 & 13.18 \\
MSW-7 & 10 & $51-54$ & 52 & 1.07 \\
MSW-7/TL & 10 & $15.6-18.6 \%$ & $17.2 \%$ & $0.99 \%$ \\
SW-10 & 10 & $41-47$ & 43 & $1.81 \%$ \\
SW-10/TL & 10 & $12.8-15.4 \%$ & $14.2 \%$ & $0.81 \%$ \\
S1 & 10 & $31-34$ & 32 & 1.07 \\
S2 & 10 & $28-32$ & 30 & 1.23 \\
S3 & 10 & $31-36$ & 33 & 1.91 \\
S4 & 10 & $34-39$ & 37 & 1.42 \\
S5 & 10 & $37-42$ & 40 & 1.62 \\
S6 & 10 & $39-45$ & 43 & 1.78 \\
S7 & 10 & $44-48$ & 46 & 1.65 \\
S8 & 10 & $44-49$ & 47 & 1.75 \\
S9 & 10 & $45-52$ & 48 & 2.50 \\
S10 & 10 & $38-46$ & 42 & 3.00 \\
S11 & 10 & $31-40$ & 35 & 2.81 \\
MD4 (ac) & 9 & $31-44$ & 39 & 4.47 \\
MD5 (ac) & 10 & $42-56$ & 47 & 4.73 \\
MD6 (ac) & 9 & $59-70$ & 63 & 4.30 \\
MD7 (ac) & 6 & $67-78$ & 74 & 3.83 \\
MD8 (ac) & 10 & $71-98$ & 89 & 8.28 \\
LV6 (ac) & 10 & $33-43$ & 38 & 3.78 \\
LV7 (ac) & 9 & $41-48$ & 45 & 2.76 \\
LV8 (ac) & 10 & $44-61$ & 52 & 5.12 \\
LV9 (ac) & 10 & $40-60$ & 53 & 5.57 \\
LTS & 10 & $205-248$ & 228 & 13.38 \\
LTS/TL & 10 & $68.8-78.8 \%$ & $74.7 \%$ & $3.21 \%$ \\
LTAS & 4 & $128-133$ & 131 & 2.63 \\
\hline
\end{tabular}

Fig. 17 (opposite page). Scanning electron micrographs showing overviews and details of Echinoderes juliae sp. nov. A. Dorsal overview. B. Lateroventral overview. Glandular cell outlets type 2 in the lateral series are marked with black-white circles. C. Segments 1 to 3, dorsal view. Inset shows close-up of subdorsal sensory spot on segment 3; scale $=1 \mu \mathrm{m}$. D. Segments 1 to 3, ventral view. E. Segments 5 to 6 , ventral view. F. Sublateral regions of segments 3 to 4 . G. Segments 4 to 6 , sublateral view. H. Sublateral to lateroventral regions of segments 7 to 8 . I. Segment 9, dorsal view. J. Segment 11 in female, dorsal view. K. Segments 10 to 11 in male, lateral view. Arrow marks laterodorsal indentation without a tube on the posterior margin of segment 10 . Abbreviations: 1tas $=$ lateral terminal accessory spine; 1ts $=$ lateral terminal spine; lvs = lateroventral spine; lvt = lateroventral tube; mdss = middorsal sensory spot; $\operatorname{mlgco} 2=$ midlateral glandular cell outlet type 2 ; pdss $=$ paradorsal sensory spot; pe $=$ penile spines; $\mathrm{pr}=$ protuberance; $\operatorname{sdgco} 2=$ subdorsal glandular cell outlet type 2 ; sdss = subdorsal sensory spot; $\operatorname{slgco} 2=$ sublateral glandular cell outlet type $2 ; \operatorname{vlgco} 2=$ ventrolateral glandular cell outlet type 2; vmss $=$ ventromedial sensory spot. 


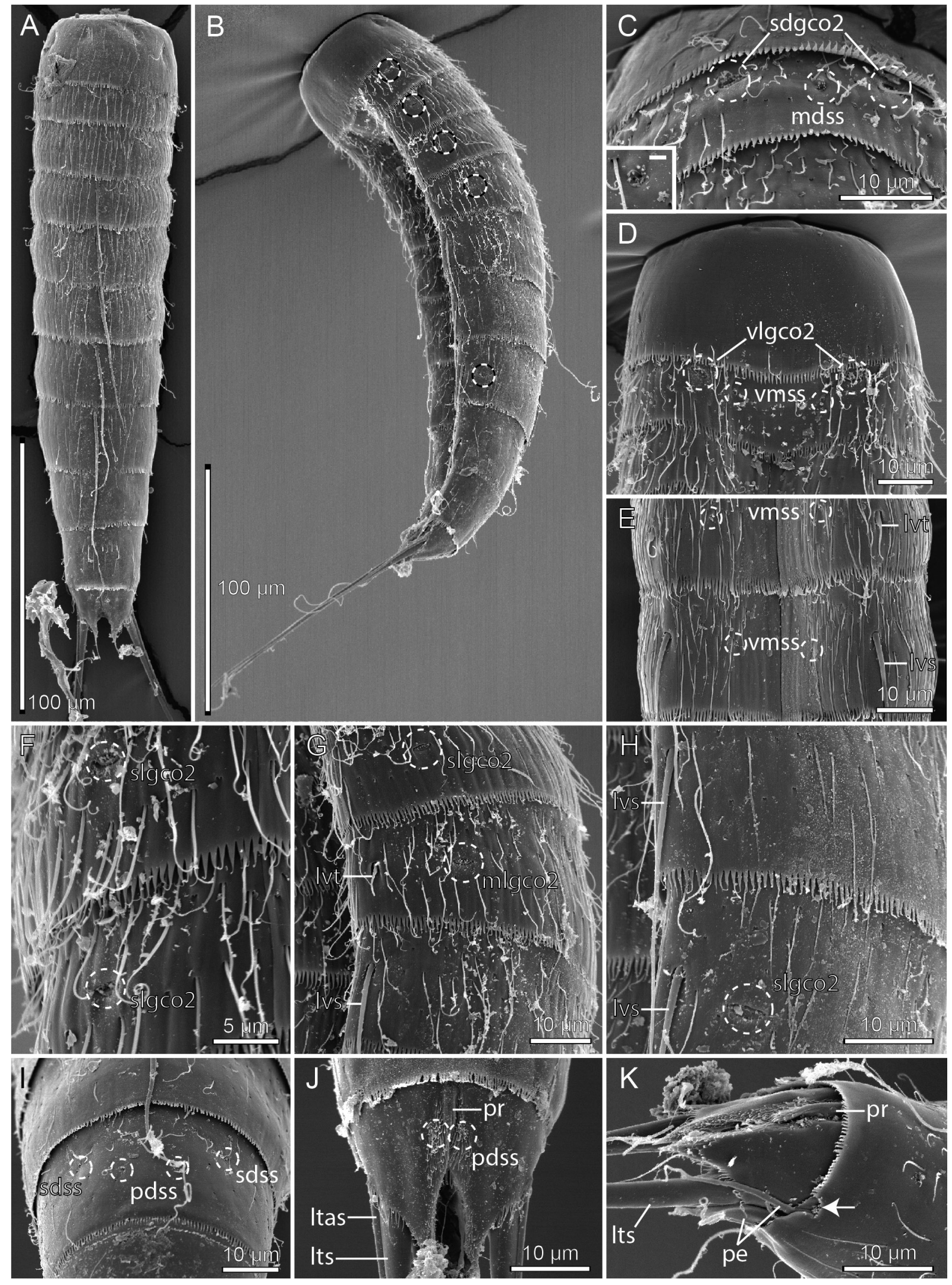


Table 11. Summary of nature and location of sensory spots, glandular cell outlets, tubes and spines arranged by series in Echinoderes juliae sp. nov. Abbreviations: LA = lateral accessory; LD = laterodorsal; $\mathrm{LV}=$ lateroventral; $\mathrm{MD}=$ middorsal; $\mathrm{ML}=$ midlateral; $\mathrm{PD}=$ paradorsal; $\mathrm{PV}=$ paraventral; $\mathrm{SD}=$ subdorsal; $\mathrm{SL}=$ sublateral; $\mathrm{VL}=$ ventrolateral; $\mathrm{VM}=$ ventromedial; $\mathrm{ac}=$ acicular spine; $\mathrm{gco} 1 / 2=$ glandular cell outlet type $1 / 2$; ltas = lateral terminal accessory spine; lts = lateral terminal spine; pe = penile spines; $\mathrm{pr}=$ protuberance; $\mathrm{si}=$ sieve plate; ss = sensory spot; $\mathrm{tu}=$ tube; $(\stackrel{+}{)})=$ female and $\left({ }^{\Uparrow}\right)=$ male conditions of sexually dimorphic characters.

\begin{tabular}{|c|c|c|c|c|c|c|c|c|c|c|c|}
\hline \multicolumn{12}{|c|}{ Position } \\
\hline Segment & MD & PD & SD & LD & ML & SL & LA & $\mathbf{L V}$ & VL & VM & PV \\
\hline 1 & gco1 & & ss & ss & & gcol & & & & & \\
\hline 2 & gcol, ss & & gco2 & Ss, gco 2 & ss & gco2 & & & gco2 & ss & \\
\hline 3 & gcol & & ss & & & gco2 & & & & gcol & \\
\hline 4 & $\mathrm{ac}$ & gco1 & & & & gco2 & & & & gcol & \\
\hline 5 & $\mathrm{ac}$ & gcol & ss & & gco2 & & & tu & & ss, gco1 & \\
\hline 6 & $\mathrm{ac}$ & ss, gco1 & ss & & ss & & & $\mathrm{ac}$ & & ss, gco 1 & \\
\hline 7 & $\mathrm{ac}$ & ss, gco1 & & & ss & & & $\mathrm{ac}$ & & ss, gco1 & \\
\hline 8 & $\mathrm{ac}$ & ss, gcol & & & & gco2 & & $\mathrm{ac}$ & & gcol & \\
\hline 9 & & ss, gcol & ss & & ss & si & & $\mathrm{ac}$ & ss & gcol & \\
\hline 10 & gco1, gco1 & & ss & & & & & & ss & & gcol \\
\hline 11 & gcol, gcol, pr & ss & & & $3 \times \mathrm{pe}($ ふ) & & $\operatorname{ltas}(P)$ & lts & & & \\
\hline
\end{tabular}

Segment 7 with acicular spines in middorsal and lateroventral positions (Figs 14A-B, 16D, 17H). Sensory spots present in paradorsal, midlateral and ventromedial positions; ventromedial sensory spots slightly more lateral than on the two preceding segments. Glandular cell outlets type 1, pachycycli, pectinate fringe of posterior margin and cuticular hairs as on preceding segment.

Segment 8 with acicular spines in middorsal and lateroventral positions (Figs 14A-B, 16G-H, 17H), and large glandular cell outlets type 2 present in sublateral positions (Figs 14B, 15B-C, 16H, 17H). Sensory spots present in paradorsal positions only (Fig. 16G). Glandular cell outlets type 1, pachycycli, pectinate fringe of posterior margin and cuticular hairs as on preceding segment.

Segment 9 with acicular spines in lateroventral positions (Figs 14B, 16H). Sensory pots present in paradorsal, subdorsal (Figs 16G, 17I), midlateral and ventrolateral (Fig. 16H) positions. Small rounded sieve plates are present in sublateral positions (Fig. 14B). Cuticular hair covering on tergal plate even less dense than on preceding segments, and subdorsal to middorsal areas only with a few scattered hairs anteriorly on segment (Fig. 17I). Glandular cell outlets type 1, pachycycli and pectinate fringe of posterior margin as on preceding segment.

Segment 10 without spines or tubes. The pectinate fringe of the posterior segment margin is interrupted and has small indentations in the laterodorsal positions where tubes often occur in species of Echinoderes, but tubes are not present in this species (Fig. 17K). Sensory spots are present in subdorsal and ventrolateral positions. Glandular cell outlets type 1 are present as two middorsal ones (Fig. 16G), and a pair in paraventral positions (Fig. 16H). A few cuticular hairs are scattered over the tergal plate and lateral parts of the sternal plates. The posterior segment margin of the tergal plate is straight, with shorter fringe tips. The margins of the sternal plates are broadly concave, also with slightly shorter fringe tips. Pachycycli as on preceding segment.

Segment 11 with lateral terminal spines (Figs 14C, 17B). Males with three pairs of penile spines (Figs 14D-E, 16F, 17K); dorsal and ventral penile spines are thin, flexible tubes, whereas the median one 
is thick, conical, and stout. Females thin and delicate, but also with rather long lateral terminal accessory spines (Figs 14A-C, 16I, 17J). A short middorsal protuberance extends from the intersegmentary joint; the protuberance is flanked by numerous minute hairs and a pair of paradorsal sensory spots (Figs 14A, D, 17J-K). Glandular cell outlets type 1 present as two middorsal ones, in association with, or underneath, the protuberance. The segment is completely devoid of cuticular hairs, besides the short hair-like extensions around the protuberance (Fig. 17J). The posterior part of the tergal plate appears to be divided by a longitudinal fissure (Fig. 17J). Because of the overlying protuberance, it is difficult to visualize how far anterior the fissure expands, but the tergal plate can at least be considered as partially divided. Tergal extensions are long and slender, with a small tooth on the inferior margin, and extending into fairly long, flexible tips (Figs 14, 16F, I). Sternal extensions shorter, but also with a short projecting tooth.

\section{Remarks}

Despite its quite typical spine formula, the distribution of glandular cell outlets type 2, combined with its slender appearance, long lateral terminal accessory spines and conspicuously shaped tergal extensions, make it very easy to distinguish E. juliae sp. nov. from all other known species. Echinoderes juliae sp. nov. can be distinguished from other congeners by the presence of glandular cell outlets type 2 in sublateral positions on segments 3 and 4 . No other known species have sublateral outlets on these segments.

Eight additional species have the combination of glandular cell outlets in subdorsal, laterodorsal, sublateral and lateroventral/ventrolateral positions on segment 2. These include E. angustus Higgins \& Kristensen, 1988, E. anniae sp. nov., E. cernunnos Sørensen et al., 2012, E. drogoni, E. obtuspinosus Sørensen et al., 2012, E. romanoi Landers \& Sørensen, 2016, E. tubilak Higgins \& Kristensen, 1988, and E. unispinosus (see Higgins \& Kristensen 1988; Sørensen et al. 2012; Landers \& Sørensen 2016; Grzelak \& Sørensen 2018; Yamasaki et al. 2018b). All of these species also have glandular cell outlets type 2 in sublateral positions on segment 8 , and five of them have midlateral glandular cell outlets type 2 on segment 5 as well. The latter are missing in E. obtuspinosus, E. anniae sp. nov. and E. unispinosus though, and none of these species can really be confused with $E$. juliae sp. nov. Also, the remaining five species differ in general appearance. E. angustus and E. tubilak furthermore differ from E. juliae sp. nov. by their having sublateral glandular cell outlets type 2 on segment 4 (Grzelak \& Sørensen 2018). Echinoderes drogoni has its tubes on segment 5 placed in lateral accessory positions (Grzelak \& Sørensen 2018), E. cernunnos has midlateral glandular cell outlets type 2 on segment 7 and very long, spinous tergal extensions (Sørensen et al. 2012), and E. romanoi has much shorter tergal extensions and lateral terminal spines (Landers \& Sørensen 2016).

Echinoderes juliae sp. nov. probably shows the greatest overall resemblance with E. cernunnos and E. drogoni. Besides other similarities in spine and glandular cell outlet distribution, all three species share a rather rare trait, namely a full or partial longitudinal division of the tergal plate of segment 11. In E. drogoni the full division of the segment is evident in females only, but could be present in males as well. The males of E. drogoni, however, have a middorsal protuberance which, as is the case in E. juliae sp. nov., obscures the examination of the anterior part of the segment (Grzelak \& Sørensen 2018). The division is very clear in E. cernunnos, but only female morphology is known for this species (Sørensen et al. 2012). In E. juliae sp. nov. the division is at least evident on the posterior half of the segment in both sexes. It is uncertain whether this suggests a closer relationship between the three species, but it is at least noteworthy that these, otherwise fairly similar species, also are the only three species of Echinoderes with full or partial tergal division of segment 11. 


\section{Echinoderes lupherorum sp. nov. urn:1sid:zoobank.org:act:B3E96033-83C3-4924-8FFE-3592E427620C}

Figs 18-20, Tables 12-13

\section{Diagnosis}

Echinoderes with middorsal spines on segments 4 to 8, and spines in lateroventral positions on segments 6 to 9 . Tubes present in lateroventral positions on segments 2 and 5, and in midlateral positions of segment 10 . Very minute glandular cell outlets type 2 present in subdorsal positions on segment 2 and in laterodorsal positions on segments 8 and 9. Tergal plate of segment 11 terminates in pointed, acicular tergal extensions, constituting 6 to $8 \%$ of trunk length. Males with three pairs of penile spines; females with long lateral terminal accessory spines, and papillae in ventrolateral positions of segment 7 and ventromedial positions of segment 8 .

\section{Etymology}

The second author (MR) dedicates this species to her fiancé Brach Lupher and the Lupher family - her family to be.

\section{Material examined}

\section{Holotype}

UNITED STATES OF AMERICA: adult + , US West Coast, off southern Oregon, 42 $33^{\prime} 50^{\prime \prime} \mathrm{N}$, $131^{\circ} 59^{\prime} 48^{\prime \prime}$ W, St. 2, $3601 \mathrm{~m}$ deep, collected from mud, 17 Sep. 2008, mounted in Fluoromount G on an H-S slide (NHMD-225220). See Fig. 1 for localities and Table 1 for detailed station data.

\section{Paratypes}

UNITED STATES OF AMERICA: $4 \uparrow q, 1$ $\uparrow$, same collecting data as for holotype; 1 , , St. 3 (NHMD225221-225226). All paratypes are mounted in Fluoromount G, three on H-S slides and three on glass slides.

\section{Additional non-type material}

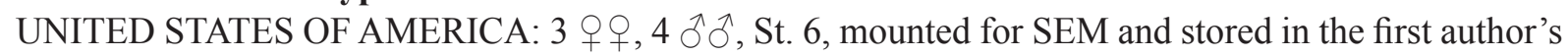
personal reference collection.

\section{Description}

Adults with head, neck and eleven trunk segments (Figs 18A-B, 19A, 20A-B). The trunk is relatively large, appears slender, tapered in both ends, and broadest from segment 5 to 8 . Lateral terminal spines are long and slender (Fig. 18C), from $80 \%$ and up to same length as the trunk, and lateral terminal accessory spines in females are shorter (Figs 18A-B), around $20 \%$ of the lateral terminal spine length. For a complete overview of measurements and dimensions, see Table 12. Distribution of cuticular structures, i.e., sensory spots, glandular cell outlets, spines and tubes, is summarized in Table 13.

The head consists of a retractable mouth cone and an introvert. Inner oral styles are present, but their exact number and arrangement could not be determined. The external mouth cone armature consists of nine outer oral styles, each with four or five basal fringe tips. The introvert sectors are defined by ten primary spinoscalids in Ring 01 . Each primary spinoscalid consists of a basal sheath and a distal end piece with a blunt tip (Fig. 20C). The basal sheaths have marginal extensions forming two layers of transverse fringes. End pieces are smooth. The arrangement of scalids follows the same pattern as in Echinoderes hviidarum sp. nov. described above; hence, see Fig. 11 for a complete overview. All spinoscalids consist of a basal sheath and a pointed end piece. The basal sheaths terminate in fringed margins in spinoscalids of Rings 02 and 04 , whereas the sheaths of Ring 03 have a median spike only. 

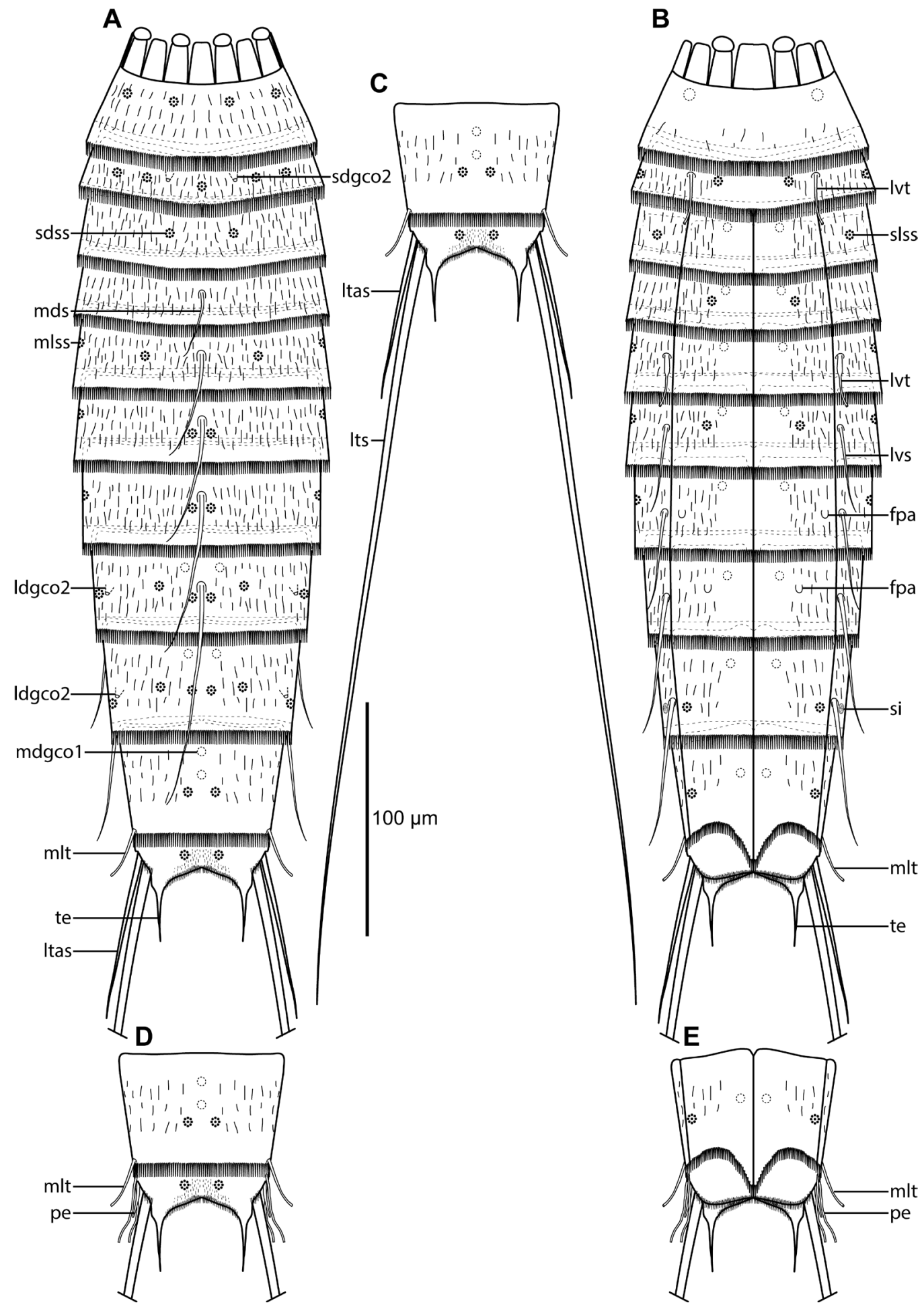

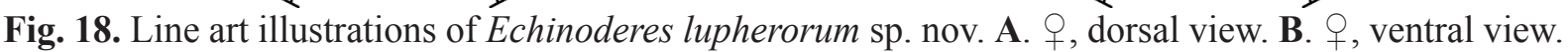
C. $\odot$, segments 10 to 11 , with lateral terminal spines drawn in full length, dorsal view. D. $\widehat{\partial}$, segments 10 to 11 , dorsal view. $\mathbf{E}$. $\widehat{\jmath}$, segments 10 to 11, ventral view. Abbreviations: fpa = female papillae; ldgco $2=$ laterodorsal glandular cell outlet type 2 ; 1tas $=$ lateral terminal accessory spine; 1ts $=$ lateral terminal spine; lvs = lateroventral spine; lvt = lateroventral tube; mdgco1 = middorsal glandular cell outlet type $1 ; \mathrm{mds}=$ middorsal spine; $\mathrm{mlss}=$ midlateral sensory spot; $\mathrm{mlt}=$ midlateral tube; $\mathrm{pe}=$ penile spines; sdgco $2=$ subdorsal glandular cell outlet type 2 ; sdss $=$ subdorsal sensory spot; $\mathrm{si}=$ sieve plate; slss $=$ sublateral sensory spot; te $=$ tergal extension . 


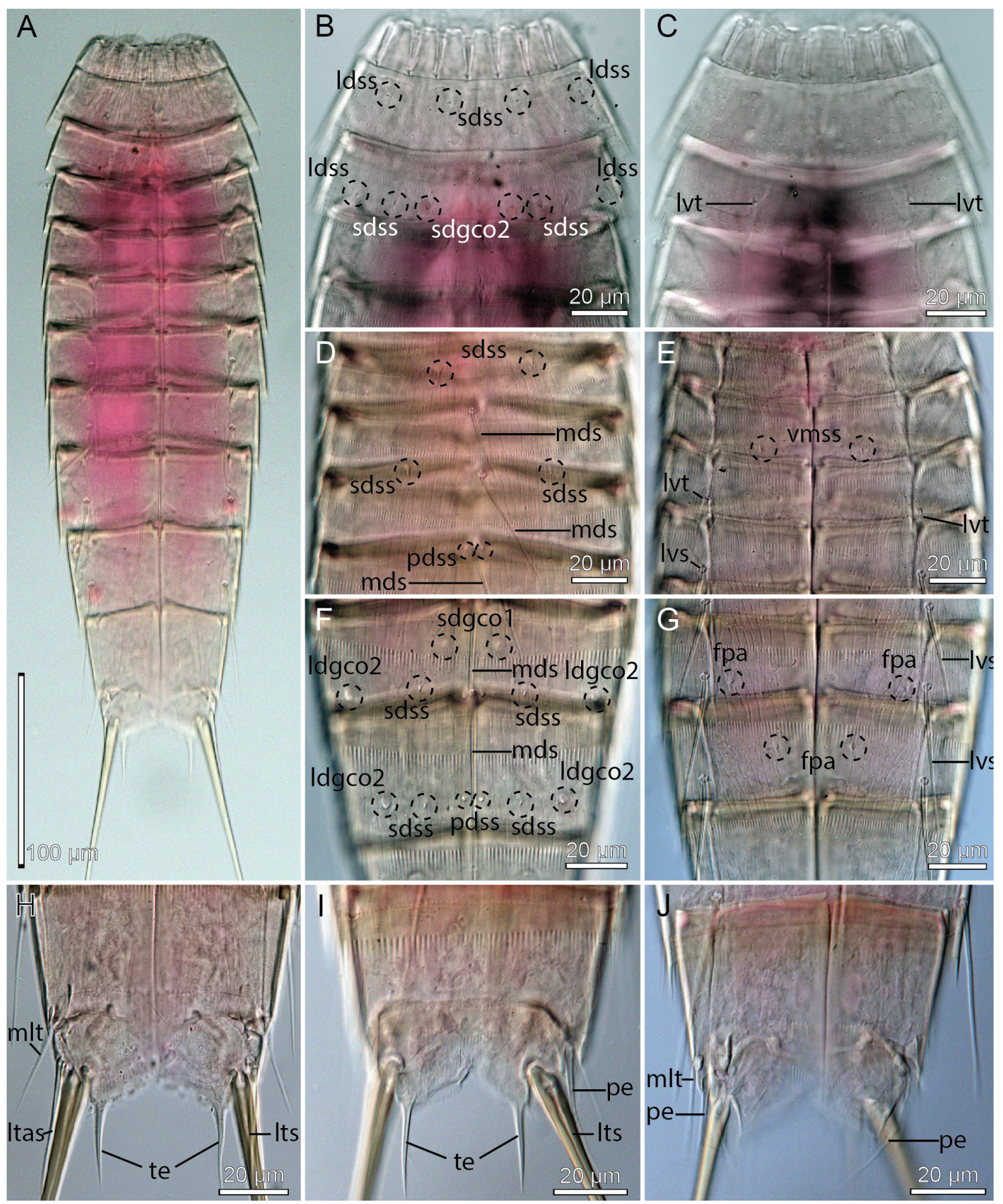

Fig. 19. Light micrographs showing overviews and details of Echinoderes lupherorum sp. nov., holotype, + (A-C, H) (NHMD-225220), paratype, o (D-G) (NHMD-225226) and paratype, §ิ (I-J) (NHMD-225225). A. Ventral overview. B. Segments 1 to 3, dorsal view. C. Segments 1 to 3, ventral view. D. Segments 3 to 6, dorsal view. E. Segments 3 to 6, ventral view. F. Segments 8 to 9, dorsal view. G. Segments 7 to 8 , ventral view. H., , segments 10 to 11 , ventral view. I. $\partial$, segments 10 to 11 , dorsal

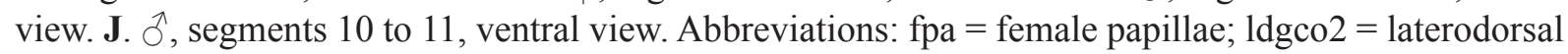
glandular cell outlet type 2; ldss = laterodorsal sensory spot; ltas = lateral terminal accessory spine; 1ts = lateral terminal spine; lvs = lateroventral spine; lvt = lateroventral tube; $\mathrm{mds}=$ middorsal spine; $\mathrm{mlt}=$ midlateral tube; pdss $=$ paradorsal sensory spot; $p e=$ penile spine; sdgco $1 / 2=$ subdorsal glandular cell outlet type 1 or 2 ; sdss = subdorsal sensory spot; te = tergal extensions; vmss = ventromedial sensory spot. 

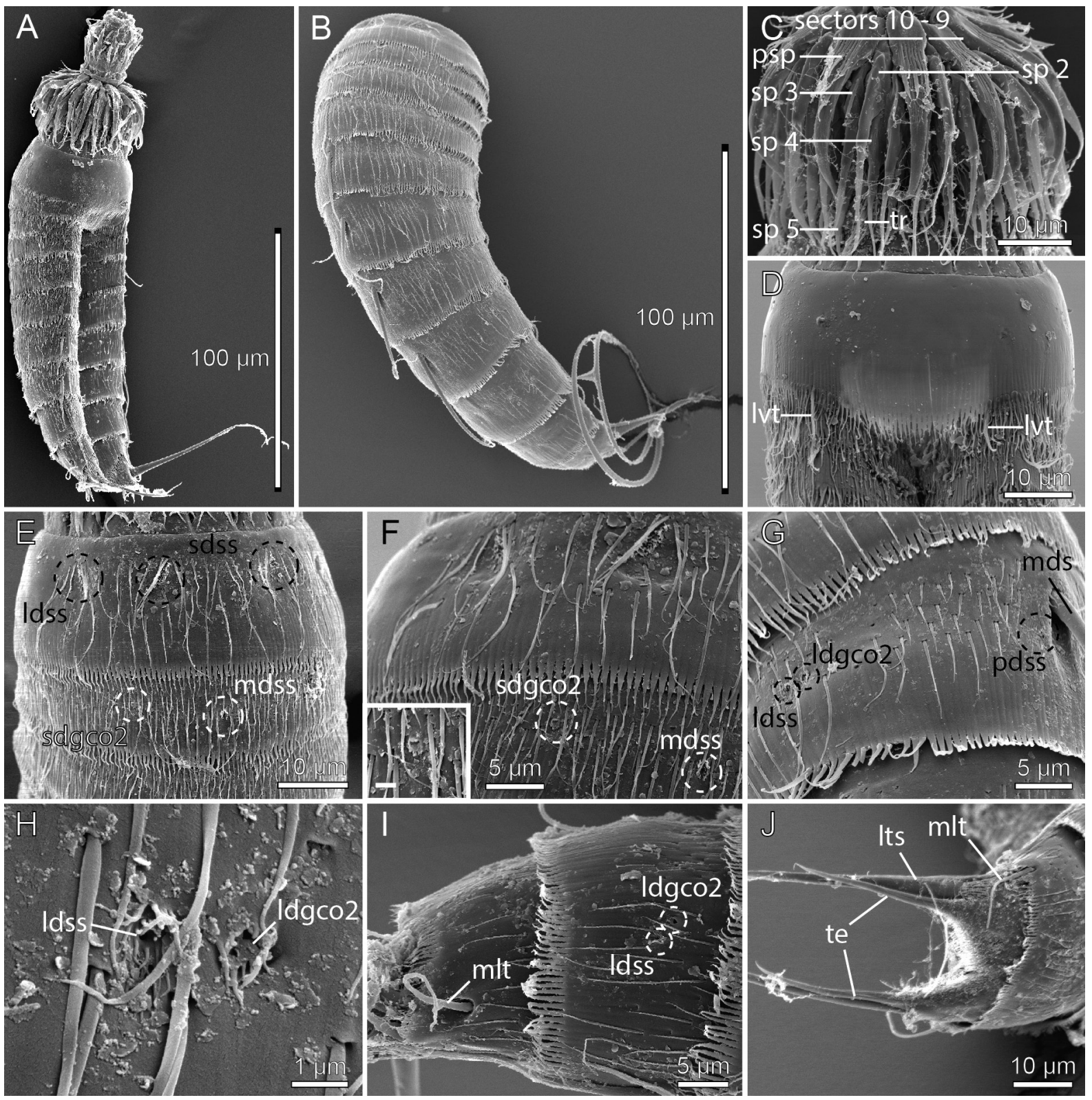

Fig. 20. Scanning electron micrographs showing overviews and details of Echinoderes lupherorum sp. nov. A. Lateroventral overview. B. Laterodorsal overview. C. Introvert sectors 10 and 9. D. Segments 1 to 3, ventral view. E. Segments 1 to 2, dorsal view. F. Detail showing middorsal (right) to laterodorsal (left) parts of segments 1 and 2. Inset shows close-up of subdorsal glandular cell outlet type 2; scale $=1 \mu \mathrm{m}$. G. Detail showing middorsal (right) to laterodorsal (left) parts of 8 . H. Close-up showing laterodorsal sensory spot and glandular cell outlet type 2 on segment 8 . I. Segments 9 to 10 , lateral view. J. 9 , segments 10 to 11, dorsal view. Abbreviations: ldgco2 = laterodorsal glandular cell outlet type 2; ldss = laterodorsal sensory spot; $1 \mathrm{ts}=$ lateral terminal spine; $1 \mathrm{vt}=$ lateroventral tube; $\mathrm{mds}=$ middorsal spine; mdss $=$ middorsal sensory spot; mlt $=$ midlateral tube; pdss $=$ paradorsal sensory spot; $p s p=$ primary spinoscalid; sdgco 2 = subdorsal glandular cell outlet type 2 ; sdss = subdorsal sensory spot; $\mathrm{sp}=$ spinoscalid followed by introvert ring number; te = tergal extensions; $\operatorname{tr}=$ trichoscalid. 
Table 12. Measurements from light microscopy of Echinoderes lupherorum sp. nov. (in $\mu \mathrm{m}$ ), including number of measured specimens (n) and standard deviation (SD). Abbreviations: (ac) = acicular spine; LTAS = lateral terminal accessory spine; LTS = lateral terminal spine; LV = lateroventral; $\mathrm{MD}=$ middorsal; $\mathrm{ML}=$ midlateral; MSW-8 = maximum sternal width, measured on segment 8 in this species; $\mathrm{S}=$ segment lengths; $\mathrm{SW}-10=$ standard width, always measured on segment $10 ; \mathrm{TE}=$ tergal extension; $\mathrm{TL}=$ trunk length; $(\mathrm{tu})=$ tube.

\begin{tabular}{ccccc}
\hline Character & n & Range & Mean & SD \\
\hline TL & 7 & $331-415$ & 371 & 36.42 \\
MSW-8 & 6 & $75-81$ & 78 & 2.16 \\
MSW-8/TL & 6 & $19.3-23.9 \%$ & $21.0 \%$ & $1.83 \%$ \\
SW-10 & 6 & $65-71$ & 67 & 2.58 \\
SW-10/TL & 6 & $15.7-20.2 \%$ & $18.1 \%$ & $1.77 \%$ \\
S1 & 7 & $35-42$ & 39 & 2.54 \\
S2 & 7 & $33-37$ & 35 & 1.46 \\
S3 & 7 & $39-43$ & 41 & 1.50 \\
S4 & 7 & $42-47$ & 45 & 1.90 \\
S5 & 7 & $42-52$ & 48 & 3.78 \\
S6 & 7 & $50-57$ & 54 & 2.70 \\
S7 & 7 & $54-60$ & 57 & 2.34 \\
S8 & 7 & $54-62$ & 59 & 2.82 \\
S9 & 7 & $59-62$ & 61 & 1.38 \\
S10 & 7 & $44-51$ & 49 & 2.51 \\
S11 & 7 & $53-58$ & 56 & 1.91 \\
MD4 (ac) & 7 & $31-36$ & 33 & 1.95 \\
MD5 (ac) & 6 & $40-48$ & 44 & 3.27 \\
MD6 (ac) & 7 & $50-67$ & 54 & 6.00 \\
MD7 (ac) & 6 & $54-83$ & 70 & 11.15 \\
MD8 (ac) & 6 & $90-128$ & 112 & 16.97 \\
LV6 (ac) & 6 & $32-43$ & 38 & 4.32 \\
LV7 (ac) & 7 & $45-53$ & 48 & 3.86 \\
LV8 (ac) & 7 & $53-68$ & 60 & 5.77 \\
LV9 (ac) & 7 & $54-74$ & 64 & 7.63 \\
ML10 (tu) & 6 & $29-34$ & 31 & 1.75 \\
TE & 7 & $24-28$ & 26 & 1.40 \\
TE/TL & 7 & $6.0-8.2 \%$ & $7.2 \%$ & $0.94 \%$ \\
LTS & 6 & $324-355$ & 341 & 12.45 \\
LTS/TL & 6 & $80.5-100.9 \%$ & $91.5 \%$ & 7.40 \\
LTAS & 6 & $62-83$ & 75 & \\
\hline & & & & $59 \%$ \\
\hline
\end{tabular}

Spinoscalids of Rings 05 to 07 are composed as those in the preceding ring, but with shorter end pieces (Figs 11, 20C).

The neck has 16 placids, measuring $18 \mu \mathrm{m}$ in length, except for the slightly longer midventral ones, measuring $20 \mu \mathrm{m}$ in length. The midventral placid is also broadest, measuring $16 \mu \mathrm{m}$ in width at its base, whereas all others are narrower, measuring $10 \mu \mathrm{m}$ in width at their bases. Four dorsal and two ventral trichoscalid plates are present; trichoscalid plates are fairly small, and rounded to oval.

Segment 1 consists of a complete cuticular ring. Sensory spots are located on the anterior half of the segment, but not at the anterior margin in subdorsal and laterodorsal positions (Figs 18A, 19B, 20E); 
Table 13. Summary of nature and location of sensory spots, glandular cell outlets, tubes and spines arranged by series in Echinoderes lupherorum sp. nov. Abbreviations: LA = lateral accessory; LD = laterodorsal; $\mathrm{LV}=$ lateroventral; $\mathrm{MD}=$ middorsal; $\mathrm{ML}=$ midlateral; $\mathrm{PD}=$ paradorsal; $\mathrm{PV}=$ paraventral; $\mathrm{SD}=$ subdorsal; $\mathrm{SL}=$ sublateral; $\mathrm{VL}=$ ventrolateral; $\mathrm{VM}=$ ventromedial; $\mathrm{ac}=$ acicular spine; $\mathrm{gco} 1 / 2=$ glandular cell outlet type $1 / 2$; ltas = lateral terminal accessory spine; lts = lateral terminal spine; $\mathrm{pa}=$ papilla; pe = penile spines; $\mathrm{si}=$ sieve plate; ss = sensory spot; tu = tube; $($ + $)=$ female and $(\widehat{\delta})=$ male conditions of sexually dimorphic characters. ${ }^{*}=$ indicates that the structure is not present in all specimens.

\begin{tabular}{|c|c|c|c|c|c|c|c|c|c|c|c|}
\hline \multicolumn{11}{|c|}{ Position } & \multirow[b]{2}{*}{ PV } \\
\hline Segment & MD & PD & SD & LD & ML & SL & LA & LV & VL & VM & \\
\hline 1 & & & ss & SS & & & & gco1 & & & \\
\hline 2 & ss & & gco2, ss & ss & & & & tu & & ss & \\
\hline 3 & & & ss & & & ss & & & & gcol & \\
\hline 4 & $\mathrm{ac}$ & & & & & & & & & ss, gcol & \\
\hline 5 & $\mathrm{ac}$ & & ss & & ss & & & tu & & gcol & \\
\hline 6 & $\mathrm{ac}$ & ss & & & ss & & & $\mathrm{ac}$ & & ss, gco1 & \\
\hline 7 & $\mathrm{ac}$ & ss & & & ss & & & ac & $\mathrm{pa}($ ( $)$ & $\operatorname{ss}\left(\delta^{\lambda}\right), \operatorname{gco} 1$ & \\
\hline 8 & $\mathrm{ac}$ & ss & gco1, ss* & gco2, ss & & & & $\mathrm{ac}$ & & $\mathrm{pa}($ ( $), \mathrm{gco} 1$ & \\
\hline 9 & & ss & gcol, ss & gco2, ss & & & si & $\mathrm{ac}$ & ss & gcol & \\
\hline 10 & gcol, gcol & ss & & & tu & & & & ss & & gcol \\
\hline 11 & & & ss & & $3 \times \mathrm{pe}(\overbrace{}^{\pi})$ & & $\operatorname{ltas}(P)$ & lts & & & \\
\hline
\end{tabular}

sensory spots are small and rounded, with a few papillae. Their minute size, combined with the dense hair covering on most segments, makes it very difficult to observe the sensory spots in SEM, and often they are more easily observed in LM. Glandular cell outlets type 1 only observed in lateroventral positions. Dorsal and lateral sides have scattered cuticular hairs, whereas the ventral side is nearly devoid of hairs (Fig. 20D-E). The posterior segment margin is nearly straight, terminating in a pectinate fringe with long and flexible fringe tips.

Segment 2 consists of a complete cuticular ring. The pachycyclus of the anterior segment margin is relatively thin and not interrupted. Very minute glandular cell outlets type 2 are present in subdorsal positions (Figs 18A, 19B, 20E-F), and well-developed tubes in lateroventral positions (Figs 18B, 19C, 20D). Sensory spots are located in middorsal (Fig. 20E-F), subdorsal, laterodorsal (Fig. 19B) and ventromedial positions. Glandular cell outlets type 1 are not observed. A secondary pectinate fringe is present near the anterior segment margin of this and the following segments, but it is usually covered by the preceding segment. On this and the following eight segments, the cuticular hairs are bracteate and densely cover the dorsal and lateral areas. The posterior segment margin is as on the preceding segment.

Segment 3, and the remaining segments, consist of one tergal and two sternal plates (Figs 18B, 19A, $\mathrm{C}, \mathrm{E}, \mathrm{G})$. The pachycyclus of the anterior segment margin is well-developed and interrupted at the tergosternal junctions and middorsally. Sensory spots are present in subdorsal (Fig. 19D) and sublateral positions, as well as glandular cell outlets type 1 in ventromedial positions. Cuticular hairs densely cover the tergal plate and the lateral halves of the sternal plates. The posterior segment margin is nearly straight, with fringe tips as on the preceding segment.

Segment 4 with a middorsal acicular spine (Figs 18A, 19D). There are sensory spots and glandular cell outlets type 1 present in ventromedial positions (Fig. 19E). Pachycycli, pectinate fringe of posterior margin and cuticular hairs as on preceding segment. 
Segment 5 with a middorsal acicular spine and well-developed tubes in lateroventral positions (Figs 18A-B, 19D-E); tubes have weakly developed, yet visible bases and lateral wings. Sensory spots are present in subdorsal (Fig. 19D) and midlateral positions. Cuticular hairs, glandular cell outlets type 1 , pachycycli and pectinate fringe of posterior margin as on preceding segment.

Segment 6 with acicular spines in middorsal and lateroventral positions (Figs 18A-B, 19D-E). Sensory spots present in paradorsal (Fig. 19D), midlateral and ventromedial positions. Glandular cell outlets type 1, pachycycli, pectinate fringe of posterior margin and cuticular hairs as on preceding segment.

Segment 7 with acicular spines in middorsal and lateroventral positions (Figs 18A-B, 19F-G). Sensory spots present in paradorsal and midlateral positions, and males in addition with sensory spots in ventromedial positions. Females with papillary structures in ventrolateral positions (Figs 18B, 19G); the structures are quite prominent in LM (Fig. 19G), but hardly visible in SEM. Glandular cell outlets type 1 , pachycycli, pectinate fringe of posterior margin and cuticular hairs as on preceding segment.

Segment 8 with acicular spines in middorsal and lateroventral positions (Figs 18A-B, 19F-G). Very minute glandular cell outlets type 2 present in laterodorsal positions (Figs 18A, 19F, 20G-H). Sensory spots present in paradorsal (Fig. 20G), subdorsal (Fig. 19F) and laterodorsal (Fig. 20G-H) positions (one specimen without subdorsal sensory spots though (Fig. 20G), and one too dirty to confirm their presence). Female specimens with papillary structures in ventromedial positions (Figs 18B, 19G). Glandular cell outlets type 1 present in subdorsal (Fig. 19F) and ventromedial positions. Pachycycli, pectinate fringe of posterior margin and cuticular hairs as on preceding segment.

Segment 9 with acicular spines in lateroventral positions (Figs 18B). Very minute glandular cell outlets type 2 present in laterodorsal positions (Figs 18A, 19F, 20I). Sensory spots present in paradorsal (Fig. 19F), subdorsal (Fig. 19F), laterodorsal (Fig. 20I) and ventrolateral positions. Small rounded sieve plates are present in lateral accessory positions (Fig. 18B). Glandular cell outlets type 1 are present in subdorsal and ventromedial positions. Cuticular hair covering on tergal plate is less dense than on the preceding segments, and the subdorsal to middorsal areas have no hair at all. Pachycycli and pectinate fringe of posterior margin as on preceding segment.

Segment 10 with tubes in midlateral positions (Figs 18, 19H, J, 20I-J); tubes appear fairly stout and are usually much easier to observe in LM (Fig. 19H) than tubes on segment 10 in other species of Echinoderes; differentiated bases and lateral wings apparently not present. Sensory spots are present in paradorsal and ventrolateral positions. Glandular cell outlets type 1 are present as two middorsal ones and a pair in paraventral positions. Cuticular hairs are scattered over the tergal plate and lateral parts of the sternal plates, but not as densely as on preceding segments. The posterior segment margin of the tergal plate is straight, whereas the margins of the sternal plates are broadly concave. Pachycycli as on preceding segment.

Segment 11 with long lateral terminal spines (Fig. 18C ). Males with three pairs of penile spines (Figs 18D-E, 19J); dorsal and ventral penile spines are thin, and quite long flexible tubes, whereas the median one is thick, conical, and stout. Females with lateral terminal accessory spines (Figs 18A$\mathrm{B}, 19 \mathrm{H})$. Sensory spots present in subdorsal positions. The segment is completely devoid of cuticular hairs, besides the short hair-like extensions in the mid- to subdorsal areas. Tergal extensions are long and slender, extending into long but yet delicate spinous tips (Figs 18, 19H-I, 20J); tergal extensions measure 24 to $28 \mu \mathrm{m}$, equal to 6 to $8 \%$ of trunk length. Sternal extensions shorter and rounded.

\section{Remarks}

Due to their close resemblance, diagnostic remarks for $E$. lupherorum sp. nov. will follow below together with remarks for E. yamasakii sp. nov. 
SØRENSEN M.V. et al., Deep-sea Echinoderidae from the Northwest Pacific

\section{Echinoderes yamasakii sp. nov. urn:1sid:zoobank.org:act:000C173B-417F-4BE9-8EF5-75D584F3AF19}

Figs 21-23, Tables 14-15

\section{Diagnosis}

Echinoderes with middorsal spines on segments 4 to 8 and spines in lateroventral positions on segments 6 to 9 . Tubes present in lateroventral positions on segments 2 and 5, and in midlateral positions of segment 10 . Very minute glandular cell outlets type 2 present in subdorsal positions on segment 2 and in laterodorsal positions on segments 8 and 9 . Tergal plate of segment 11 terminates in conspicuously long, pointy, acicular tergal extensions, constituting 13 to $16 \%$ of trunk length. Males with three penile spines; females with relatively short and delicate lateral terminal accessory spines, and papillae in ventromedial positions of segment 7 .

\section{Etymology}

The species is named after Hiroshi Yamasaki in recognition of his many contributions to kinorhynch taxonomy, morphology and phylogeny, and in particular his recent descriptions of the first deep-sea Echinoderes.

\section{Material examined}

Holotype

UNITED STATES OF AMERICA: + , US West Coast, California, off Monterey, 36 $40^{\prime} 52^{\prime \prime} \mathrm{N}$, $122^{\circ} 49^{\prime} 37^{\prime \prime}$ W, St. 6, $2.719 \mathrm{~m}$ deep, from mud, 24 Sep. 2008, mounted in Fluoromount G on a glass slide (NHMD-226471). See Fig. 1 for localities and Table 1 for detailed station data.

\section{Paratypes}

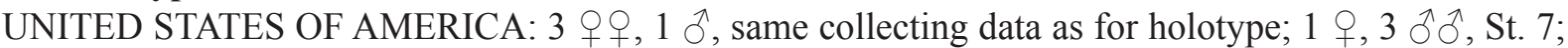
2 우, 1 § , St. 8. All paratypes are mounted in Fluoromount G on glass slides (NHMD-226472-226482).

\section{Additional non-type material}

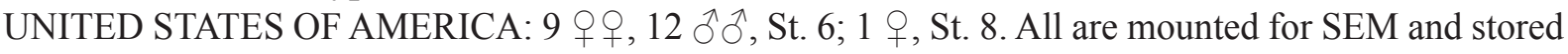
in the first author's personal reference collection.

\section{Description}

Adults with head, neck and eleven trunk segments (Figs 21A-B, 22A, 23A-B). The trunk is relatively short, terminating in a very large tergal extension. Lateral terminal spines are fairly short, but thick at their bases, from $40 \%$ to $57 \%$ of trunk length (Figs $21 \mathrm{~A}-\mathrm{B}, 22 \mathrm{~A}$ ), and lateral terminal accessory spines in females even shorter and less rigid (Fig. 21A-B). The cuticle appears very thin, which made it difficult to observe cuticular structures such as glandular cell outlets type 1 and sensory spots in LM. Observation of sensory spots was also obscured in SEM due to the dense hair covering and their very minute size. Hence, some glandular cell outlets type 1 and sensory spots might have been overlooked in the following description. For a complete overview of measurements and dimensions, see Table 14. Distribution of cuticular structures, i.e., sensory spots, glandular cell outlets, spines and tubes, is summarized in Table 15.

The head consists of a retractable mouth cone and an introvert. Inner oral styles are present, but their exact number and arrangement could not be determined. The external mouth cone armature consists of nine outer oral styles, each with four or five basal fringe tips. The introvert sectors are defined by ten primary spinoscalids in Ring 01 . Each primary spinoscalid consists of a basal sheath and a distal end piece with a blunt tip. The basal sheaths have marginal extensions forming two layers of transverse 

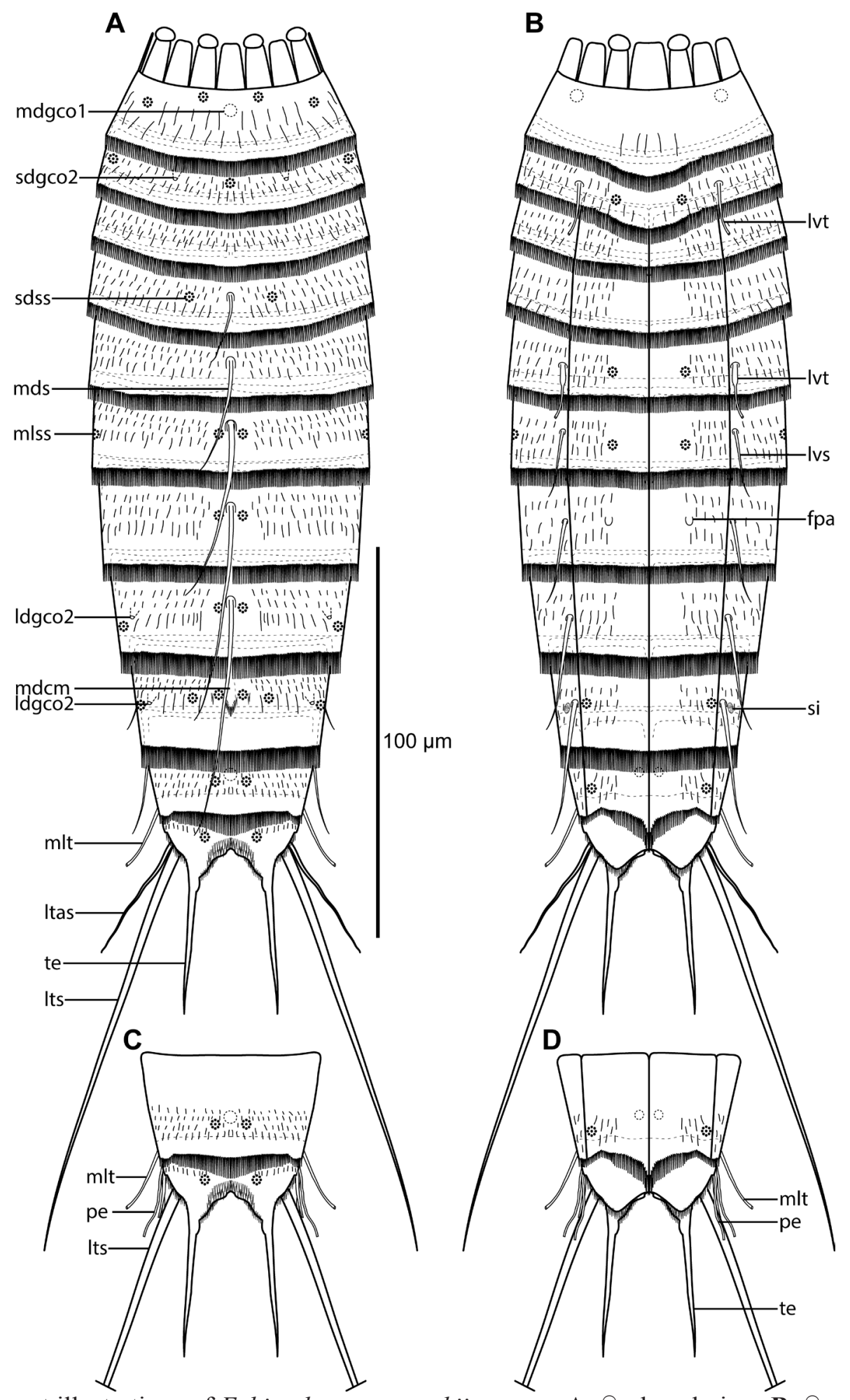

Fig. 21. Line art illustrations of Echinoderes yamasakii sp. nov. A. $\circ$, dorsal view. B. , , ventral view. C. $\partial^{\lambda}$, segments 10 to 11, dorsal view. D. Oे $^{2}$, segments 10 to 11, ventral view. Abbreviations: fpa = female papillae; $\operatorname{ldgco} 2=$ laterodorsal glandular cell outlet type 2 ; 1tas = lateral terminal accessory spine; 1 ts $=$ lateral terminal spine; lvs = lateroventral spine; $1 \mathrm{vt}=$ lateroventral tube; $\mathrm{mdcm}=$ middorsal cuticular marking; $\mathrm{mdgco} 1=$ middorsal glandular cell outlet type $1 ; \mathrm{mds}=$ middorsal spine; $\mathrm{mlss}=$ midlateral sensory spot; $\mathrm{mlt}=$ midlateral tube; $\mathrm{pe}=$ penile spines; $\operatorname{sdgco} 2=$ subdorsal glandular cell outlet type 2 ; sdss $=$ subdorsal sensory spot; $\mathrm{si}=$ sieve plate; te $=$ tergal extension. 

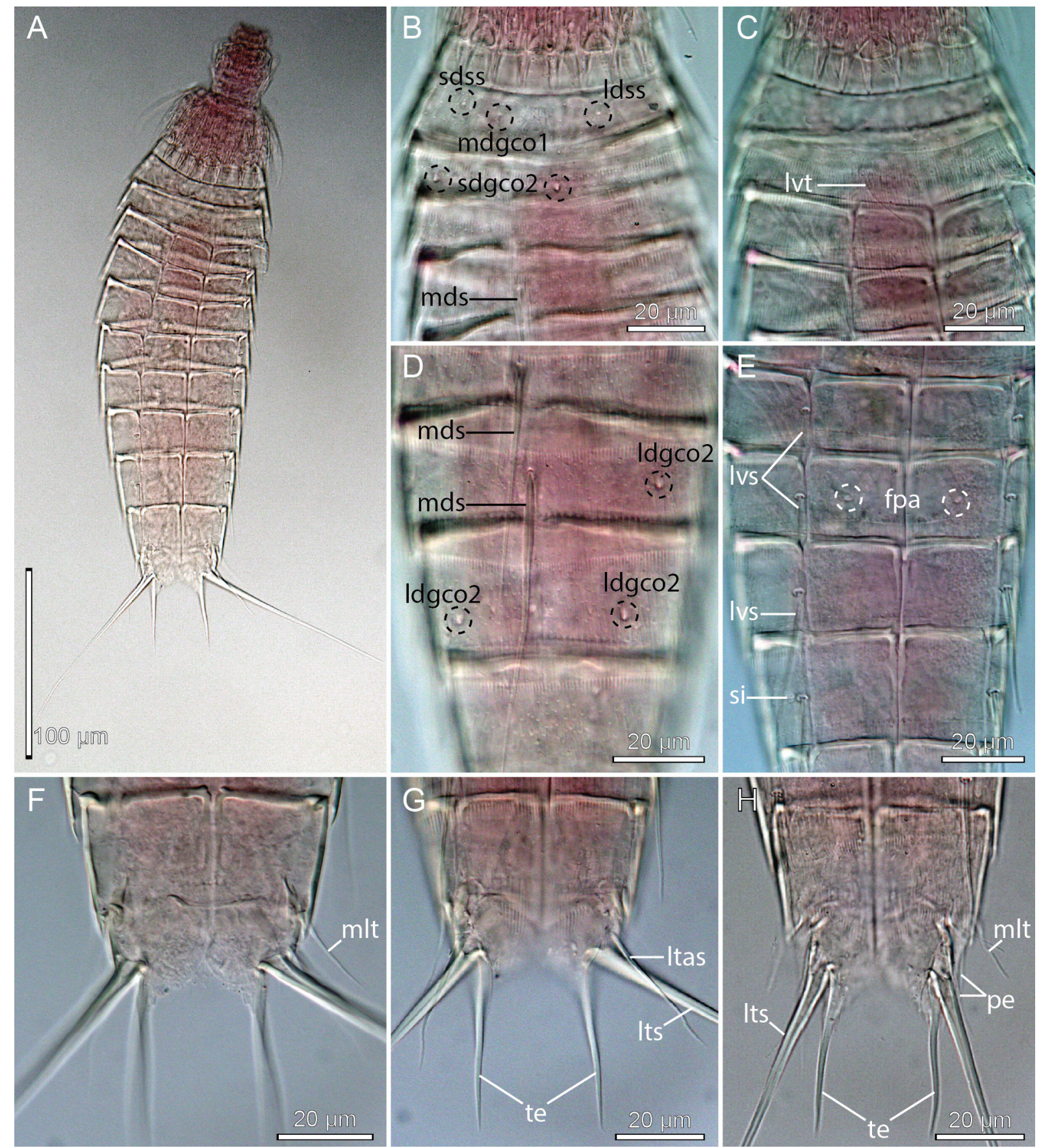

Fig. 22. Light micrographs showing overviews and details of Echinoderes yamasakii sp. nov., holotype, q (A-G) (NHMD-226471) and paratype, ô (H) (NHMD-226479). A. Ventral overview. B. Segments 1 to 4, dorsal view. C. Segments 1 to 4, ventral view. D. Segments 7 to 10, dorsal view. E. Segments 6 to 9 , ventral view. F. Segments 10 to 11 , focused on midlateral tube. G. $q$, segments 10 to 11 , ventral

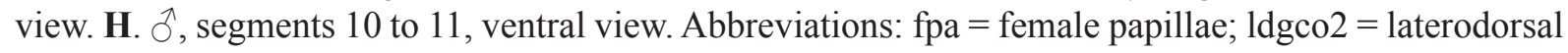
glandular cell outlet type 2; ldss = laterodorsal sensory spot; 1tas = lateral terminal accessory spine; 1 ts = lateral terminal spine; lvs = lateroventral spine; lvt = lateroventral tube; $\mathrm{mdgco} 1=$ middorsal glandular cell outlet type $1 ; \mathrm{mds}=$ middorsal spine; $\mathrm{mlt}=$ midlateral tube; $\mathrm{pe}=$ penile spine; $\operatorname{sdgco} 2=$ subdorsal glandular cell outlet type 2 ; sdss = subdorsal sensory spot; si = sieve plate; te = tergal extensions . 
Table 14. Measurements from light microscopy of Echinoderes yamasakii sp. nov. (in $\mu \mathrm{m}$ ), including number of measured specimens (n) and standard deviation (SD). Abbreviations: (ac) = acicular spine; LTAS = lateral terminal accessory spine; LTS = lateral terminal spine; LV = lateroventral; $\mathrm{MD}=$ middorsal; ML = midlateral; MSW-6 = maximum sternal width, measured on segment 6 in this species; $\mathrm{S}=$ segment lengths; $\mathrm{SW}-10=$ standard width, always measured on segment $10 ; \mathrm{TE}=$ tergal extension; $\mathrm{TL}=$ trunk length; $(\mathrm{tu})=$ tube.

\begin{tabular}{ccccc}
\hline Character & n & Range & Mean & SD \\
\hline TL & 10 & $217-255$ & 238 & 11.38 \\
MSW-6 & 10 & $46-52$ & 50 & 1.95 \\
MSW-6/TL & 10 & $18.8-24.0 \%$ & $20.9 \%$ & $1.46 \%$ \\
SW-10 & 10 & $38-43$ & 42 & 1.86 \\
SW-10/TL & 10 & $16.3-19.8 \%$ & $17.5 \%$ & $1.16 \%$ \\
S1 & 10 & $23-25$ & 25 & 0.71 \\
S2 & 10 & $21-23$ & 22 & 0.57 \\
S3 & 10 & $23-26$ & 25 & 1.14 \\
S4 & 10 & $24-29$ & 27 & 1.64 \\
S5 & 10 & $29-35$ & 31 & 2.08 \\
S6 & 10 & $29-36$ & 33 & 2.60 \\
S7 & 10 & $31-38$ & 34 & 2.45 \\
S8 & 10 & $33-45$ & 37 & 3.43 \\
S9 & 10 & $35-40$ & 38 & 1.51 \\
S10 & 10 & $29-35$ & 32 & 2.08 \\
S11 & 10 & $54-60$ & 57 & 1.91 \\
MD4 (ac) & 10 & $16-25$ & 22 & 2.87 \\
MD5 (ac) & 9 & $26-37$ & 34 & 3.67 \\
MD6 (ac) & 8 & $44-54$ & 47 & 3.23 \\
MD7 (ac) & 8 & $50-58$ & 53 & 2.82 \\
MD8 (ac) & 8 & $64-71$ & 68 & 2.39 \\
LV6 (ac) & 8 & $17-23$ & 21 & 1.69 \\
LV7 (ac) & 9 & $22-28$ & 25 & 1.99 \\
LV8 (ac) & 9 & $27-35$ & 32 & 2.60 \\
LV9 (ac) & 10 & $34-41$ & 37 & 2.31 \\
ML10 (tu) & 10 & $16-24$ & 21 & 2.21 \\
TE & 10 & $33-35$ & 34 & 0.74 \\
TE/TL & 10 & $12.9-15.7 \%$ & $14.3 \%$ & $0.77 \%$ \\
LTS & 10 & $95-123$ & 110 & 8.21 \\
LTS/TL & 10 & $40.4-56.7 \%$ & $46.2 \%$ & $5.02 \%$ \\
LTAS & 5 & $32-36$ & 34 & 1.52 \\
\hline & & & &
\end{tabular}

Fig. 23 (opposite page). Scanning electron micrographs showing overviews and details of Echinoderes yamasakii sp. nov. A. Lateral overview. B. Ventral overview. C. Segments 1 to 2, dorsal view. D. Segments 1 to 3, laterodorsal view. E. Segments 1 to 2, ventral view. F. Detail showing laterodorsal glandular cell outlet type 2 and sensory spot on segment 8. G. Segment 9, laterodorsal view. H. Segment 9, subdorsal view. I. $q$, segments 10 to 11 , laterodorsal view. J. $q$, segments 10 to 11 , ventral view. K. $0^{\wedge}$, segments 10 to 11, subdorsal view. Abbreviations: ldgco $2=$ laterodorsal glandular cell outlet type 2; ldss = laterodorsal sensory spot; 1tas = lateral terminal accessory spine; lts = lateral terminal spine; $\operatorname{lvgco} 1=$ lateroventral glandular cell outlet type $1 ;$ lvs = lateroventral spine; lvt = lateroventral tube; $\mathrm{mdcm}=$ middorsal cuticular marking; mds = middorsal spine; mdss = middorsal sensory spot; $\mathrm{mlt}=$ midlateral tube; pdss $=$ paradorsal sensory spot; $\mathrm{pe}=$ penile spine; sdgco $2=$ subdorsal glandular cell outlet type 2 ; sdss = subdorsal sensory spot; te = tergal extensions; vlss = ventrolateral sensory spot; vmss $=$ ventromedial sensory spot. 

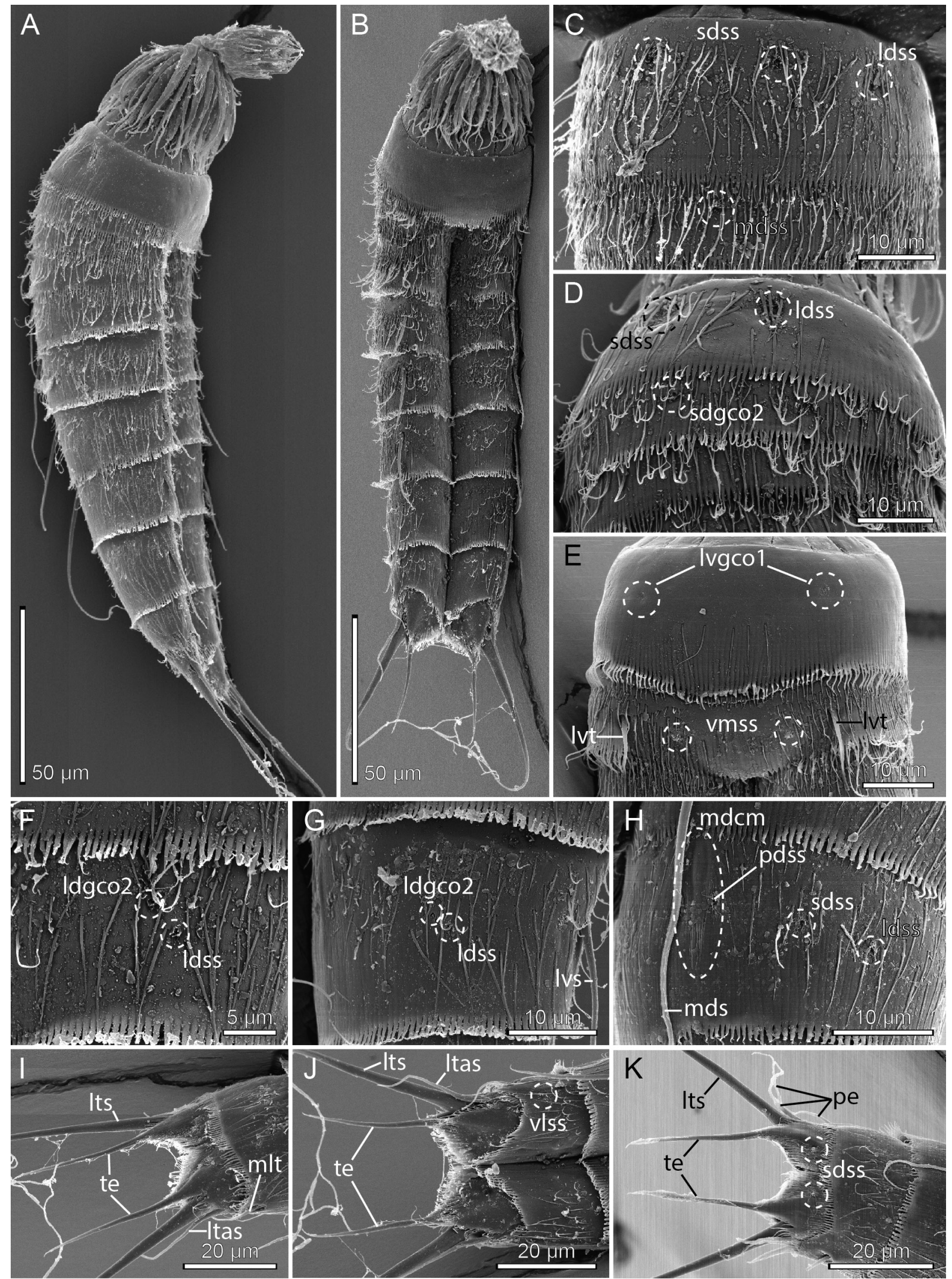
Table 15. Summary of nature and location of sensory spots, glandular cell outlets, tubes and spines arranged by series in Echinoderes yamasakii sp. nov. Abbreviations: LA = lateral accessory; LD = laterodorsal; $\mathrm{LV}=$ lateroventral; $\mathrm{MD}=$ middorsal; $\mathrm{ML}=$ midlateral; $\mathrm{PD}=$ paradorsal; $\mathrm{PV}=$ paraventral; $\mathrm{SD}=$ subdorsal; $\mathrm{VL}=$ ventrolateral; $\mathrm{VM}=$ ventromedial; $\mathrm{ac}=$ acicular spine; gcol $/ 2=$ glandular cell outlet type 1/2; 1tas = lateral terminal accessory spine; lts = lateral terminal spine; mdcm, middorsal cuticular marking; pa, papilla; pe = penile spines; $s i=$ sieve plate; ss = sensory spot; tu = tube; (\&), female and $(\widehat{\jmath})$, male conditions of sexually dimorphic characters.

\begin{tabular}{|c|c|c|c|c|c|c|c|c|c|c|}
\hline \multicolumn{11}{|c|}{ Position } \\
\hline Segment & MD & PD & SD & LD & ML & LA & $\mathbf{L V}$ & VL & VM & PV \\
\hline 1 & gco1 & & SS & ss & & & gcol & & & \\
\hline 2 & ss & & gco2 & ss & & & tu & & ss & \\
\hline \multicolumn{11}{|l|}{3} \\
\hline 4 & $\mathrm{ac}$ & & ss & & & & & & & \\
\hline 5 & ac & & & & & & tu & & ss & \\
\hline 6 & ac & ss & & & ss & & ac & & ss & \\
\hline 7 & $\mathrm{ac}$ & ss & & & & & $\mathrm{ac}$ & & $\mathrm{pa}($ ( $)$ & \\
\hline 8 & ac & ss & & gco2, ss & & & ac & & & \\
\hline 9 & mdcm & Ss & Ss & gco2, ss & & si & $\mathrm{ac}$ & Ss & & \\
\hline 10 & gcol & ss & & & tu & & & ss & & gcol \\
\hline 11 & & & Ss & & $3 \times \mathrm{pe}($ Љ) & $\operatorname{ltas}(+)$ & lts & & & \\
\hline
\end{tabular}

fringes. End pieces are smooth. The arrangement of scalids follows the same pattern as in Echinoderes hviidarum sp. nov. described above; hence, see Fig. 11 for a complete overview. All spinoscalids consist of a basal sheath and a pointed end piece. The basal sheaths terminate in fringed margins in spinoscalids of Rings 02 and 04, whereas the sheaths of Ring 03 have a median spike only. The spinoscalids of Rings 05 to 07 are composed as those in the preceding ring, but with shorter end pieces.

The neck has 16 placids, measuring $13 \mu \mathrm{m}$ in length, except for the slightly longer midventral ones, measuring $15 \mu \mathrm{m}$ in length. The midventral placid is also broadest, measuring $13 \mu \mathrm{m}$ in width at its base, whereas all others are narrower, measuring $7 \mu \mathrm{m}$ in width at their bases. Four dorsal and two ventral trichoscalid plates are present; trichoscalid plates are fairly small and rounded to oval.

Segment 1 consists of a complete cuticular ring. Sensory spots are located in subdorsal and laterodorsal positions (Figs 21A, 22B, 23C-D); subdorsal ones are located very close to the anterior segment margin, whereas laterodorsal ones are slightly more posterior; sensory spots are small and rounded, with a few papillae. Glandular cell outlets type 1 are present in middorsal (Fig. 22B) and lateroventral (Fig. 23E) positions. Dorsal and lateral sides are densely covered with cuticular hairs, whereas the ventral side has a short midventral transverse row with 4-6 hairs only (Fig. 23E). The posterior segment margin is nearly straight, with a short ventral extension, terminating in a pectinate fringe with long and flexible fringe tips.

Segment 2 consists of a complete cuticular ring. The pachycyclus of the anterior segment margin is relatively thin and not interrupted. Very minute glandular cell outlets type 2 are present in subdorsal positions (Figs 21A, 22B, 23D) and well-developed tubes in lateroventral positions (Figs 21B, 22C, $23 \mathrm{E}$ ); tubes are gradually tapered towards their tips, without distinct bases or lateral wings (Fig. 23E). Sensory spots are located in middorsal (Fig. 23C), laterodorsal (slightly more lateral than those on segment 1) and ventromedial positions (Fig. 23E). Glandular cell outlets type 1 not observed on this or any following segment, down to segment 9 . Secondary pectinate fringe present near anterior segment margin of this and the following segments, but it is usually covered by the preceding segment. On this 
and all following segments, the cuticular hairs are bracteate, densely covering dorsal and lateral areas. Posterior segment margin as on preceding segment.

Segment 3, and the remaining segments, consist of one tergal and two sternal plates (Figs 21B, 22A, C, E). The pachycyclus of the anterior segment margin is well-developed and interrupted at the tergosternal and midsternal junctions and middorsally. No sensory spots were observed. Cuticular hairs densely cover the tergal plate and the lateral halves of the sternal plates. The posterior segment margin is nearly straight, with fringe tips as on preceding segment.

Segment 4 with a middorsal acicular spine (Figs 21A, 22B). Sensory spots are present in subdorsal positions. Pachycycli, pectinate fringe of posterior margin and cuticular hairs as on preceding segment.

Segment 5 with a middorsal acicular spine and well-developed tubes in lateroventral positions (Figs 21A-B); tubes have weakly developed, yet visible bases and lateral wings. Sensory spots present in ventromedial positions. Cuticular hairs, pachycycli and pectinate fringe of posterior margin as on preceding segment.

Segment 6 with acicular spines in middorsal and lateroventral positions (Figs 21A-B, 22E). Sensory spots present in paradorsal, midlateral and ventromedial positions. Cuticular hairs, pachycycli and pectinate fringe of posterior margin as on preceding segment.

Segment 7 with acicular spines in middorsal and lateroventral positions (Figs 21A-B, 22D-E). Sensory spots present in paradorsal positions. Females with papillary structures in ventromedial positions (Figs 21B, 22E); the structures are prominent in LM, but not visible in SEM. Cuticular hairs, pachycycli and pectinate fringe of posterior margin as on preceding segment.

Segment 8 with acicular spines in middorsal and lateroventral positions (Figs 21A-B, 22D-E). Very minute glandular cell outlets type 2 present in laterodorsal positions (Figs 21A, 22D, 23F). Sensory spots present in paradorsal and laterodorsal (Fig. 23F) positions. Cuticular hairs, pachycycli and pectinate fringe of posterior margin as on preceding segment.

Segment 9 with acicular spines in lateroventral positions (Figs 21B, 22E). Middorsal position with smooth area, flanked by conspicuous fringe-like extensions and a pair of paradorsal sensory spots (see mdcm on Fig. $23 \mathrm{H}$ ); the structure is visible in SEM only. Additional sensory spots present in subdorsal, laterodorsal (Fig. 23G-H) and ventrolateral positions. Very minute glandular cell outlets type 2 present in laterodorsal positions (21A, 22D, 23G). Small rounded sieve plates are present in lateral accessory positions (Figs 21B, 22E). Cuticular hair covering on tergal plate less dense than those on preceding segments. Pachycycli and pectinate fringe of posterior margin as on preceding segment.

Segment 10 with tubes in midlateral positions (Figs 21, 22F, H, 23I); tubes appear fairly stout and are much easier to observe in LM (Fig. 22F, H) than tubes on segment 10 usually are in most other species of Echinoderes; differentiated bases and lateral wings apparently not present. Sensory spots are present in paradorsal and ventrolateral (Fig. 23J) positions. A single glandular cell outlet type 1 was observed with SEM in middorsal position and a pair in paraventral positions. The cuticular hairs are scattered over the tergal plate and lateral parts of the sternal plates, but not as densely as on the preceding segments. The posterior segment margin of the tergal plate is straight, whereas the margins of the sternal plates are broadly concave, with shorter fringe tip around the tergosternal junctions and longer tips towards the paraventral positions. Pachycycli as on preceding segment.

Segment 11 with medium to short lateral terminal spines (Figs 21A-B, 22A). Males with three pairs of penile spines (Figs 21C-D, 22H, 23K); dorsal and ventral penile spines are thin, but also rather long 
and flexible tubes, whereas the median one is slightly thicker. Females with short and relatively flexible lateral terminal accessory spines (Figs 21A-B, 22G, 23I-J). Sensory spots present in subdorsal positions (Fig. 23K). The tergal plate has a few short cuticular hairs on the most anterior part, but otherwise the segment is completely devoid of hairs. Long hair-like extensions are present in the mid- to subdorsal areas. Tergal extensions are very long, extending into stout spinous tips (Figs 21, 22G-H, 23I-K); tergal extensions measure 33 to $35 \mu \mathrm{m}$, equal to 13 to $16 \%$ of trunk length. Sternal extensions shorter and rounded.

\section{Remarks for Echinoderes lupherorum sp. nov. and E. yamasakii sp. nov.}

Echinoderes lupherorum sp. nov. and E. yamasakii sp. nov. can easily be distinguished from most other congeners by their long and acicular tergal extensions of segment 11 . Only nine other species of Echinoderes have conspicuous spinous tergal extensions like this. These include E. microaperturus Sørensen et al., 2012, E. spinifurca Sørensen et al., 2005, E. sylviae Landers \& Sørensen, 2018, E. cernunnos, E. multiporus Yamasaki et al., 2018, E. higginsi Huys \& Coomans, 1989, E. rhaegali Grzelak \& Sørensen, 2017, E. arlis and E. filispinosus Adrianov, 1989 (see Adrianov \& Malakhov 1999; Huys \& Coomans 1989; Sørensen et al. 2005, 2012; Grzelak \& Sørensen 2018, in press; Yamasaki et al. 2018b; Landers \& Sørensen in press). Of these, the latter have no middorsal spines at all, and E. multiporus, E. higginsi, E. rhaegali and E. arlis have middorsal spines on segments 4, 6 and 8 only opposed to middorsal spines on segments 4 to 8 in E. lupherorum sp. nov. and E. yamasakii sp. nov. Furthermore, E. cernunnos has a rather special appearance, with large glandular cell outlets type 2 on segments 5 and 7 , four pairs of glandular cell outlets type 2 on segment 2, and the tergal plate of segment 11 divided into two (Sørensen et al. 2012); hence, this species can hardly be confused with any of those mentioned here.

This narrows us down to five rather similar and putatively closely related species, that besides the two new ones include E. microaperturus, E. spinifurca and E. sylviae. Besides the spinous and acicular tergal extensions, these species share nearly the same spine/tube formula (the exact position of the tubes on segment 2 appears to vary between the species, between being either lateroventral or ventrolateral). All five species have the tubes on segment 10 being relocated from the common laterodorsal positions to the rarer midlateral positions (erroneously referred to as laterodorsal in the description of E. spinifurca, but illustrated in midlateral positions). Furthermore, all of them appear to have female papillae on the sternal plates of segments 6,7 and/or 8, three of them (E. microaperturus, E. lupherorum sp. nov. and E. yamasakii sp. nov.) have minute glandular cell outlets type 2 in subdorsal positions on segment 2 , and four of them (the same three and E. sylviae) in laterodorsal positions of segments 8 and 9 as well (Sørensen et al. 2005, 2012; Landers \& Sørensen in press). These characters, together with the general overall similarity between the species, suggest that they might represent a group of closely related species within Echinoderes, similar to the Echinoderes coulli group (see, e.g., Sørensen 2014, Yamasaki 2016b). Hence, for now we will refer to E. lupherorum sp. nov., E. yamasakii sp. nov., E. microaperturus, E. spinifurca and E. sylviae as the Echinoderes spinifurca group. Landers \& Sørensen (in press) recently pointed out how the tergal extensions in E. microaperturus, E. spinifurca and E. sylviae differ from spinous tergal extensions in other species. In congeners with spinous tergal extensions, the pointed processes are a result of gradually tapering extensions from the tergal plate (Landers \& Sørensen 2018). This is opposite to the acicular tergal extensions in species of the Echinoderes spinifurca group, where the extensions from the tergal plate narrow abruptly around the bases of the terminal needles (see, e.g., Figs 19H-I, 20J, 22F-H, 23I-K).

Within the Echinoderes spinifurca group, the species are most easily distinguished by the length of their tergal extensions (absolute length as well as tergal extensions relative to trunk length), and the presence of glandular cell outlets type 2 on segment 2. Echinoderes yamasakii sp. nov. stands out as the species with the longest tergal extensions ( $34 \mu \mathrm{m}$ on average and $14.3 \%$ of trunk length). The conspicuously long tergal extensions make it easy to distinguish it from the species with the second 
longest extensions, E. spinifurca. Landers \& Sørensen (in press) showed that the length of the tergal extensions in E. spinifurca ranges from $25 \mu \mathrm{m}$ on average in the Atlantic Fort Pierce population, to $28 \mu \mathrm{m}$ on average in the slightly longer populations of the Gulf of Mexico, resulting in tergal extension vs trunk length ratios (TE/TL in the following) of $9.0 \%$ and $12.4 \%$, respectively. E. spinifurca furthermore lacks the glandular cell outlets type 2 (Sørensen et al. 2005; Sørensen \& Landers in press) that are present in E. yamasakii sp. nov.

The remaining three species have shorter tergal extensions: Echinoderes lupherorum sp. nov. $-26 \mu \mathrm{m}$ on average, but only a TE/TL ratio of $7.2 \%$ due to their relatively large trunk sizes; E. sylviae $-16 \mu \mathrm{m}$ on average and a TE/TL ratio of $6.6 \%$ (see Landers \& Sørensen in press); and E. microaperturus $-14 \mu \mathrm{m}$ on average and a TE/TL ratio of 5.0\% (measurements made on type material deposited at the NHMD). This puts the three species in a group with relatively low TE/TL ratio, which make their general appearance very similar. Echinoderes sylviae is most easily discriminated by its lack of subdorsal glandular cell outlets type 2 on segment 2. E. lupherorum sp. nov. and E. microaperturus are indeed very similar. They differ slightly in their distribution of sensory spots, but the most straightforward way to distinguish the species is by the relative length of their middorsal spines. Echinoderes microaperturus has conspicuously short middorsal spines that hardly extend beyond the posterior margins of the segments they attach to. By contrast, E. lupherorum sp. nov. has fairly long middorsal spines that always extend beyond the segment margins, and often beyond the posterior margin of the following segment as well.

\section{Records of known species}

Class Cyclorhagida Zelinka, 1896 sensu Sørensen et al. 2015

Order Echinorhagata Sørensen et al., 2015

Family Echinoderidae Zelinka, 1894

Genus Echinoderes Claparède, 1863

Echinoderes hakaiensis Herranz, Yangel \& Leander, 2017

\section{Material examined}

UNITED STATES OF AMERICA: 1 adult $\widehat{\partial}$, US West Coast, California, off Monterey, 36 $46^{\circ} 52^{\prime \prime} \mathrm{N}$, 122 49'37" W, St. 6, 2719 m deep, 24 Sep. 2008, mounted in Fluoromount G (NHMD-223924); 1 ð’, same collecting data as for preceding, mounted for SEM and stored in the first author's personal reference collection. See Fig. 1 for localities and Table 1 for detailed station data.

\section{Notes on distribution, morphology and comparison with type material}

The two recorded specimens show a very close resemblance with E. hakaiensis, a species described from the coast of British Columbia, Canada (Herranz et al. 2018). The single specimen mounted for LM has a trunk length of $320 \mu \mathrm{m}$, which is very close to the mean length of the type specimens $(324 \mu \mathrm{m})$. Moreover, spine and segment lengths are within the range of the type material. The distribution of spines, tubes, sensory spots and glandular cell outlets correspond in detail to the original description given by Herranz et al. (2018), and re-examination of paratypes deposited at NHMD confirmed this compliance. The specimens are not illustrated herein, since no new or different structures were found.

The only considerable difference regards the habitat. Echinoderes hakaiensis was described from a depth of 88-140 m, and is thus a part of the shelf or sublittoral fauna. The recorded specimens originate from the bathyal fauna, which suggests that the species is not limited by depth preferences, but can be found along the American west coast, throughout the sublittoral to bathyal zones. 
Echinoderes cf. unispinosus Yamasaki, Neuhaus \& George, 2018

Figs 24-25, Tables 16-17

\section{Material examined}

UNITED STATES OF AMERICA: 2 adult $\widehat{\partial} \widehat{\partial}$, St. $1 ; 2$ adult $q \phi, 1$ adult $\widehat{\partial}$, St. $3 ; 3$ adult $q \phi, 1$ adult $\widehat{\partial}$, St. 4. All specimens mounted in Fluoromount G (NHMD-227016-227024). See Fig. 1 for localities and Table 1 for detailed station data.

\section{Other material}

UNITED STATES OF AMERICA: $3 \hat{\jmath} \widehat{\jmath}$, St. $3 ; 1 \hat{\jmath}$, St. 5 . All mounted for SEM and stored in the first author's personal reference collection.

\section{Notes on distribution, morphology and comparison with type material}

A complete overview of measurements and dimensions is presented in Table 16, and the distribution of cuticular structures, i.e., sensory spots, glandular cell outlets and spines is summarized in Table 17.

Echinoderes unispinosus was recently described from the deep-sea plains around Sedlo Seamount in the Northwest Atlantic, north of the Azores, at a depth of 2875 m (Yamasaki et al. 2018b). Besides being among the first bathyal species of Echinoderes to be described, E. unispinosus shows several unusual characters that make it highly distinct among congeners. These include the single middorsal spine on segment 4 (Figs 24D, 25G) and lateroventral spines on segments 6 and 7 only (Figs 24E, 25H-I), combined with the presence of glandular cell outlets type 2 on segments 1, 2, 5 and 8 (Figs 24B-C, E-F, 25C, E-F, H-J). As stressed by Yamasaki et al. (2018b) this species is distinguished very easily by its characteristic spine and outlet pattern.

The material examined for the present study yielded specimens with a very similar morphology (Figs 24-25). Their general appearance is identical with that of E. unispinosus, their meristic data is within the range or very close to those of the type specimens (compare Table 16 with Yamasaki et al. 2018b), and all taxonomically significant characters, i.e., spines and glandular cell outlets type 2, fit E. unispinosus perfectly. The only observed differences between the Pacific specimens from the present study and the Atlantic specimens from the type locality are: sublateral sensory spots on segments 3 and 9 (Fig. 25J), observed in the Pacific population only, subdorsal sensory spots on segment 8, observed in the Atlantic population only, and sensory spots on segments 5 to 7 which occur midlaterally in the Atlantic population, and more sublaterally in the Pacific population (Fig. 25I).

The identity of the Pacific population leaves a taxonomic challenge. On the one hand, even though we can observe minor differences, these are so few and insignificant that they can hardly justify the description of a new species. Furthermore, Yamasaki et al. (2018b) did not have specimens available for

Fig. 24 (opposite page). Light micrographs showing overviews and details of non-types of Echinoderes cf. unispinosus Yamasaki, Neuhaus \& George, 2018, §̊ (A, H) (NHMD-227016), o (B-E, G) (NHMD227020) and $q$ (F) (NHMD-227019). A. Ventral overview. B. Segments 1 to 5, dorsal view. C. Segments 1 to 5 , ventral view. D. Segments 4 to 7, dorsal view. E. Segments 5 to 8 , ventral view. F. Segments 7 to 9 , focused on sublateral glandular cell outlet type 2 on segment 8 . G. P, segments 10 to 11 , ventral view. H. $\widehat{\jmath}$, segments 9 to 11 , ventral view. Abbreviations: lagco $2=$ lateral accessory glandular cell outlet type 2 ; ldgco 2 = laterodorsal glandular cell outlet type $2 ;$ lts = lateral terminal spine; lvs = lateroventral spine; mds = middorsal spine; pdss $=$ paradorsal sensory spot; $\mathrm{pe}=$ penile spine; sdgco $2=$ subdorsal glandular cell outlet type 2 ; sdss $=$ subdorsal sensory spot; $\mathrm{si}=$ sieve plate; slgco $2=$ sublateral glandular cell outlet type 2 ; te $=$ tergal extensions; vlgco $2=$ ventrolateral glandular cell outlet type 2 ; vmss $=$ ventromedial sensory spot. 

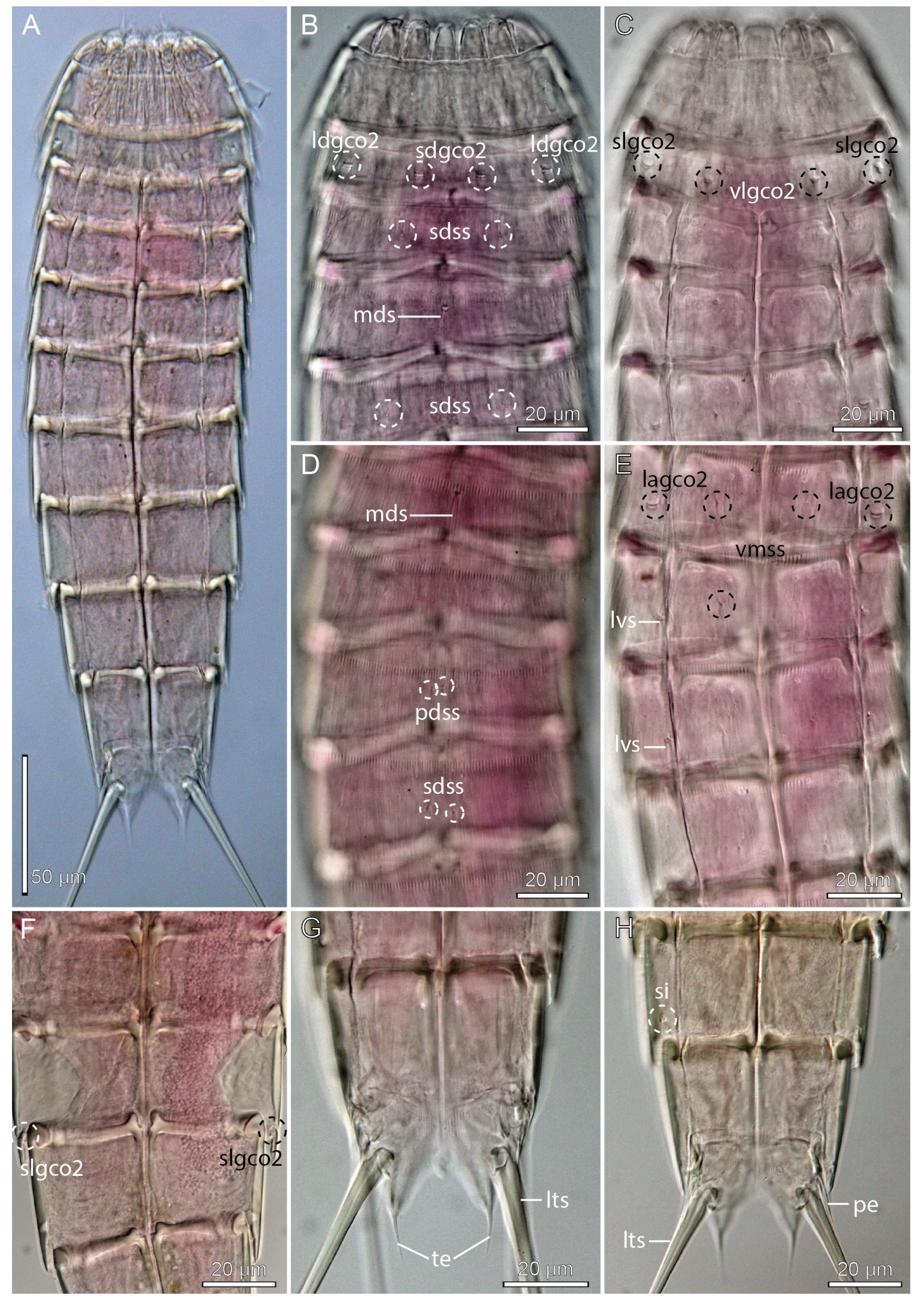

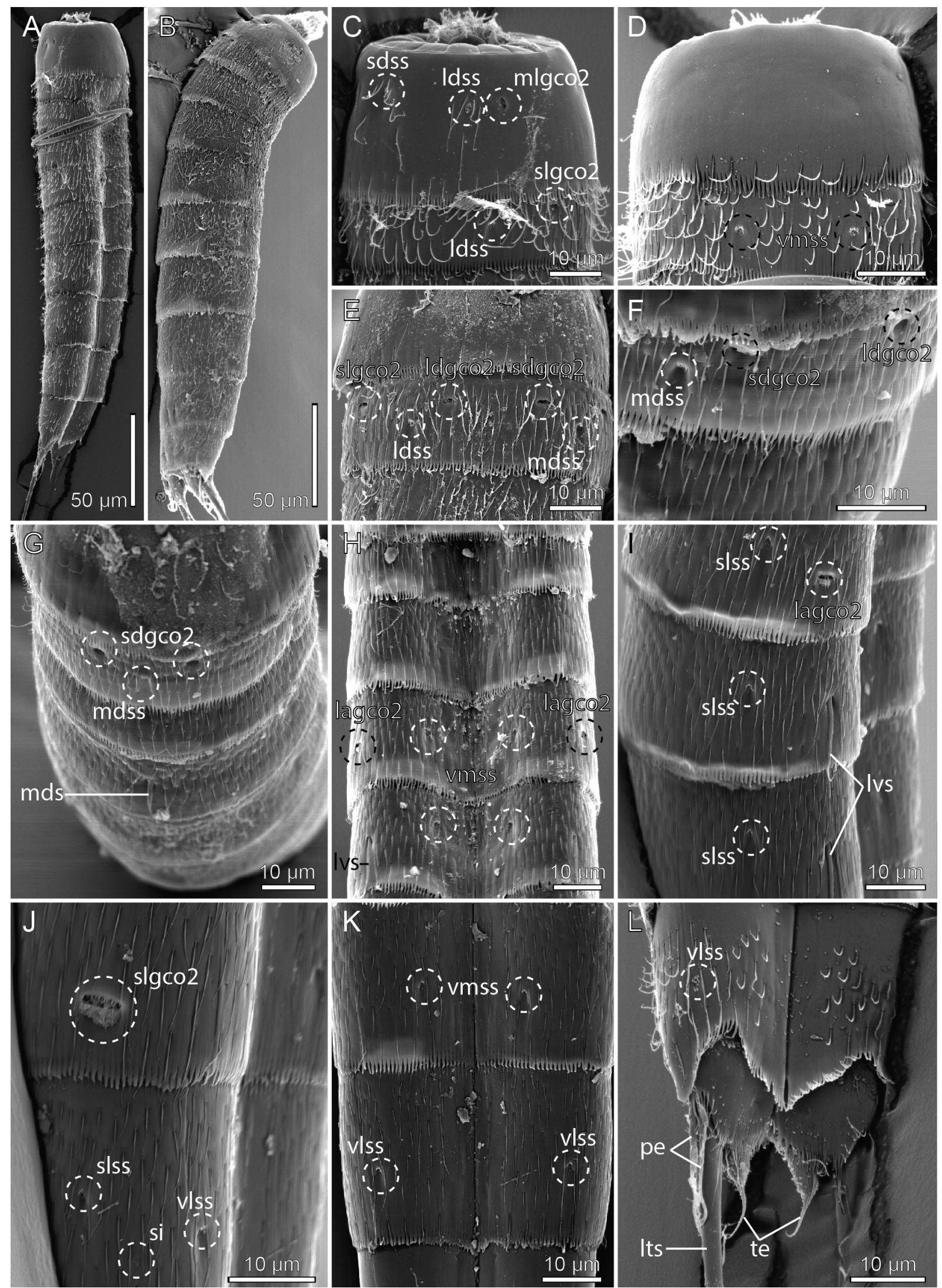
Table 16. Measurements from light microscopy of Echinoderes cf. unispinosus (in $\mu \mathrm{m}$ ), including number of measured specimens (n) and standard deviation (SD). Abbreviations: (ac) = acicular spine; LTAS = lateral terminal accessory spine; LTS = lateral terminal spine; LV = lateroventral; $\mathrm{MD}=$ middorsal; MSW-7 = maximum sternal width, measured on segment 7 in this species; $\mathrm{S}=$ segment lengths; SW-10 = standard width, always measured on segment $10 ; \mathrm{TL}=$ trunk length.

\begin{tabular}{ccccc}
\hline Character & $\mathbf{n}$ & Range & Mean & SD \\
\hline TL & 7 & $286-321$ & 305 & 13.72 \\
MSW-7 & 7 & $49-54$ & 51 & 1.80 \\
MSW-7/TL & 6 & $15.4-18.2 \%$ & $16.8 \%$ & $1.13 \%$ \\
SW-10 & 8 & $41-42$ & 41 & 0.52 \\
SW-10/TL & 7 & $12.9-14.4 \%$ & $13.6 \%$ & $0.67 \%$ \\
S1 & 7 & $32-36$ & 34 & 1.25 \\
S2 & 7 & $29-32$ & 31 & 1.13 \\
S3 & 7 & $32-36$ & 34 & 1.35 \\
S4 & 8 & $34-38$ & 36 & 1.31 \\
S5 & 8 & $37-42$ & 39 & 1.92 \\
S6 & 8 & $38-44$ & 42 & 2.19 \\
S7 & 8 & $42-48$ & 45 & 2.00 \\
S8 & 8 & $44-50$ & 47 & 2.10 \\
S9 & 8 & $42-49$ & 45 & 2.49 \\
S10 & 8 & $38-47$ & 42 & 3.54 \\
S11 & 8 & $37-39$ & 38 & 0.71 \\
MD4 (ac) & 2 & $24-25$ & 25 & 0.71 \\
LV6 (ac) & 5 & $17-19$ & 18 & 1.00 \\
LV7 (ac) & 5 & $17-19$ & 18 & 1.00 \\
LTS & 8 & $198-237$ & 226 & 12.87 \\
LTS/TL & 7 & $69.2-79.8 \%$ & $73.9 \%$ & $3.94 \%$ \\
LTAS & 5 & $56-78$ & 66 & 9.14 \\
\hline
\end{tabular}

SEM and the specimens they had for LM were not in an optimal condition. Hence, it cannot be ruled out that they have missed a sensory spot, or misinterpreted another structure and considered it to be a sensory spot. Visualizing sensory spots in LM can be extremely challenging, especially in mid- and sublateral positions. On the other hand, no other species of Echinoderes shows a distribution as wide as this. Even though a species like Echinoderes tchefouensis Lou, 1934 is known to have a considerable distribution, and can be found throughout East Asia and Indonesia (Sørensen et al. 2016b), its distribution still covers a smaller geographic area than the one suggested for E. unispinosus, and the distribution of

Fig. 25 (opposite page). Scanning electron micrographs showing overviews and details of Echinoderes cf. unispinosus. A. Lateroventral overview. B. Dorsolateral overview. C. Segments 1 to 2, laterodorsal view. D. Segments 1 to 2, ventral view. E. Segments 1 to 3, laterodorsal view. F. Segments 2 to 3, subdorsal view G. Segments 1 to 4, dorsal view. H. Segments 3 to 6, ventral view. I. Segments 5 to 7, lateral view. J. Segments 8 to 9, lateral view. K. Segments 8 to 9, ventral view. L. 3 , segments 10 to 11 , ventral view. Abbreviations: lagco $2=$ lateral accessory glandular cell outlet type 2 ; ldgco $2=$ laterodorsal glandular cell outlet type 2 ; ldss = laterodorsal sensory spot; 1 ts = lateral terminal spine; lvs $=$ lateroventral spine; $\mathrm{mds}=$ middorsal spine; $\mathrm{mdss}=$ middorsal sensory spot; $\mathrm{mlgco} 2=$ laterodorsal glandular cell outlet type 2 ; pe = penile spine; $\operatorname{sdgco} 2=$ subdorsal glandular cell outlet type 2 ; sdss $=$ subdorsal sensory spot; $\mathrm{si}=$ sieve plate; $\mathrm{slgco} 2=$ sublateral glandular cell outlet type 2 ; slss $=$ sublateral sensory spot; te $=$ tergal extensions; vlss $=$ ventrolateral sensory spot; vmss $=$ ventromedial sensory spot. 
Table 17. Summary of nature and location of sensory spots, glandular cell outlets, tubes and spines arranged by series in Echinoderes cf. unispinosus. Abbreviations: LA = lateral accessory; $\mathrm{LD}=$ laterodorsal; $\mathrm{LV}=$ lateroventral; $\mathrm{MD}=$ middorsal; $\mathrm{ML}=$ midlateral; $\mathrm{PD}=$ paradorsal; $\mathrm{PV}=$ paraventral; $\mathrm{SD}=$ subdorsal; $\mathrm{SL}=$ sublateral; $\mathrm{VL}=$ ventrolateral; $\mathrm{VM}=$ ventromedial $; \mathrm{ac}=$ acicular spine $; \mathrm{gco} 1 / 2=$ glandular cell outlet type $1 / 2$; las = lateral terminal accessory spine; lts = lateral terminal spine; pe $=$ penile spines; si $=$ sieve plate; ss = sensory spot; $(+)=$ female and $(\overbrace{}^{\lambda})=$ male conditions of sexually dimorphic characters; $*=$ marks characters differing in presence/absence from the original species description of Yamasaki et al. $(2018 \mathrm{~b}) ;^{(*)}=$ marks characters also present in the original species description of Yamasaki et al. (2018b), but in a slightly different position.

\begin{tabular}{|c|c|c|c|c|c|c|c|c|c|c|c|}
\hline \multirow[b]{2}{*}{ Segment } & \multicolumn{8}{|c|}{ Position } & \multirow[b]{2}{*}{$\mathbf{V L}$} & \multirow[b]{2}{*}{ VM } & \multirow[b]{2}{*}{ PV } \\
\hline & MD & PD & SD & LD & ML & SL & LA & $\mathbf{L V}$ & & & \\
\hline 1 & gco1 & & Ss & ss & gco2 & gcol & & gcol & & & \\
\hline 2 & gco1, ss & & gco2 & gco2, ss & & gco2 & & & gco2 & ss & \\
\hline 3 & gco1 & & ss & & & ss* & & & & gcol & \\
\hline 4 & $\mathrm{ac}$ & gco1 & & & & & & & & gcol & \\
\hline 5 & gcol & & SS & & & $\mathrm{SS}^{(*)}$ & gco2 & & & gco1, ss & \\
\hline 6 & & gcol, ss & & & & $\mathrm{SS}^{(*)}$ & & $\mathrm{ac}$ & & gcol, ss & \\
\hline 7 & gco1 & & ss & & & $\mathrm{Ss}^{(*)}$ & & ac & & gcol, ss & \\
\hline 8 & & gcol, ss & no ss* & & & gco2 & & & & gcol, ss & \\
\hline 9 & & gcol, ss & & ss & & ss* & $\mathrm{si}^{(*)}$ & & ss & gco1 & \\
\hline 10 & gco1, gco1 & & ss & & & & & & SS & & gcol \\
\hline 11 & gcol, gcol & & ss & & $3 \times \mathrm{pe}\left({ }^{\pi}\right)$ & & $\operatorname{ltas}(P)$ & lts & & & \\
\hline
\end{tabular}

E. tchefouensis appears much more continuous, with numerous records of the species throughout its distributional range (Lou 1934; Higgins \& Kristensen 1988; Sørensen et al. 2012; 2016b). As for the Pacific record of E. unispinosus, this leaves us with two options: 1) deep-sea species of Echinoderes might show a much wider distributional range than congeners from more shallow water. This option cannot be ruled out completely, since our knowledge of deep-sea Echinoderes is extremely limited, and has not been addressed until very recently (Yamasaki et al. 2018a, 2018b; Grzelak \& Sørensen in press). Alternatively, 2) the Pacific population represents a different species, closely related with E. unispinosus, but with morphological differences restricted to a few sensory spots. We might here feel inclined to support the second option, mostly based on the geographic distance between the two populations, but then again, we would hesitate in providing a formal description of the Pacific population as a distinct species, based on the present material. The question could perhaps be solved in the future if more material, and in particular clean specimens for SEM, were made available from the type locality of E. unispinosus, but ideally the problem should be approached by a molecular comparison of the two populations.

Genus Fissuroderes Neuhaus \& Blasche, 2006

Fissuroderes higginsi Neuhaus \& Blasche, 2006

Figs 26-27, Table 18

\section{Material examined}

UNITED STATES OF AMERICA: 1 adult $\widehat{\jmath}$, St. 3, mounted in Fluoromount G (NHMD-227025). See Fig. 1 for localities and Table 1 for detailed station data. 


\section{Other material}

UNITED STATES OF AMERICA: 1 adult $\widehat{\alpha}$, St. 7, mounted for SEM and stored in the first author's personal reference collection.

\section{Notes on morphology and comparison with type material}

A summary of the distribution of cuticular structures, i.e., sensory spots, glandular cell outlets, spines and tubes is provided in Table 18 .

Fissuroderes higginsi was described from New Zealand, from depths ranging from 40 to $885 \mathrm{~m}$ (Neuhaus \& Blasche 2006). The species is highly characteristic by its displacement of the lateral spine on segment 8 to a sublateral position (note that Neuhaus \& Blasche (2006) refer to the spines as lateral accessory, but line art and LM images show it in a sublateral position), and glandular cell outlets type 2 arranged in a laterodorsal series on segments 5, 6, 8 and 9 .

The material examined for the present study yielded two specimens (Figs 26-27) that are nearly identical to F. higginsi as described by Neuhaus \& Blasche (2006). The meristic data (segment and spine lengths) of the single specimen mounted for LM were all about 10-20\% larger than those of the type material, but segment to spine length dimensions were the same, including the conspicuously long middorsal spine on segment 8 . Morphologically, the recorded specimens were nearly identical with the type specimens. The only noted differences were 1) a pair of subdorsal sensory spots on segment 3 , reported from the type material, but not visible in the specimens from the present study, and 2) the dorsal tubes on segment 2 that are laterodorsal in the type specimens, but occur in a more subdorsal position in the Californian specimens (Fig. 26C). These minor differences can be neglected as either uncertainties (the sensory spots) or intraspecific variation (the tubes), and we therefore feel confident that the recorded specimens are F. higginsi.

There is obviously a considerable depth range between the New Zealand (40 to $885 \mathrm{~m}$ depth) and the Californian populations (3675-3853 m depth), but we see a similar trend in the depth preferences of E. hakaiensis, which again stresses that depth might play a minor role for species adapted to live on the shelf and below the sublittoral zone. Again, the species has a surprisingly large distribution. It might not be as extreme as was the case for E. unispinosus, but there is still a considerable distance between the type locality in New Zealand and the Californian deep-sea. This could support that deep-sea kinorhynchs actually show greater distributional ranges than species from shallower habitats.

\section{Discussion}

This study showed that the northeast Pacific deep-sea holds a rich and diverse kinorhynch fauna. More than one thousand kinorhynch specimens were collected from the eight sampling sites. Fifty-eight specimens were kentrorhagids, and only six were pycnophyids, leaving $900+$ specimens of echinoderids. A majority of the specimens could not be identified to species-level, either because they were juveniles or because of their general condition, but this clearly indicates that the deep-sea kinorhynch fauna is also dominated by echinoderids - just as the case is in many coastal habitats.

Most of the recorded species were, not surprisingly, new to science. Hence, the most surprising and puzzling findings were the already known species. The least surprising was the presence of E. hakaiensis. This species was described from Calvert Island in British Columbia, Canada (Herranz et al. 2018), and even though it is about $800 \mathrm{~km}$ north of the northernmost station in the present study, it is still fair to consider E. hakaiensis as a component of northwest American kinorhynch fauna. This species was also described from only $92 \mathrm{~m}$ depth, but with Sea Otter Valley connecting the bottom around Calvert Island with the drop-off at the continental shelf it would be fairly easy for the species to disperse between coastal and much deeper water. We have similar examples showing that depth in itself does not play 

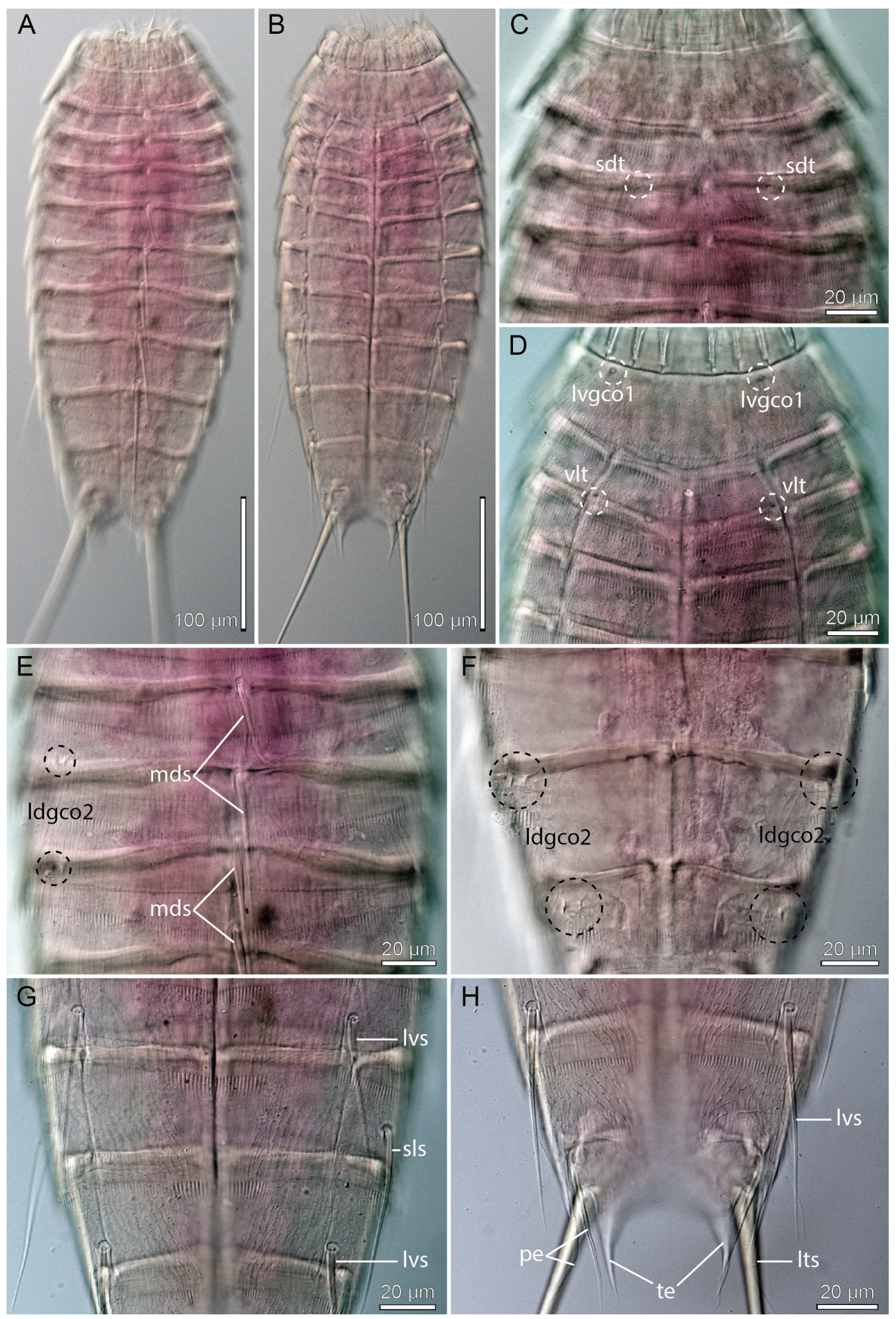

Fig. 26. Light micrographs showing overviews and details of Fissuroderes higginsi Neuhaus \& Blasche, 2006, non-type, ô (NHMD-227025). A. Dorsal overview. B. Ventral overview. C. Segments 1 to 4, dorsal view. D. Segments 1 to 4, ventral view. E. Segments 4 to 7, dorsal view. F. Segments 8 to 10 , dorsal view. G. Segments 7 to 10 , ventral view. H. Segments 10 to 11, ventral view. Abbreviations: $1 \mathrm{dgco} 2=$ laterodorsal glandular cell outlet type 2 ; 1ts = lateral terminal spine; lvgco1 = lateroventral glandular cell outlet type 1 ; lvs = lateroventral spine; mds = middorsal spine; pe = penile spine; $\mathrm{sdt}=$ subdorsal tube; $\mathrm{sls}=$ sublateral spine; te = tergal extensions; vlt = ventrolateral tube. 

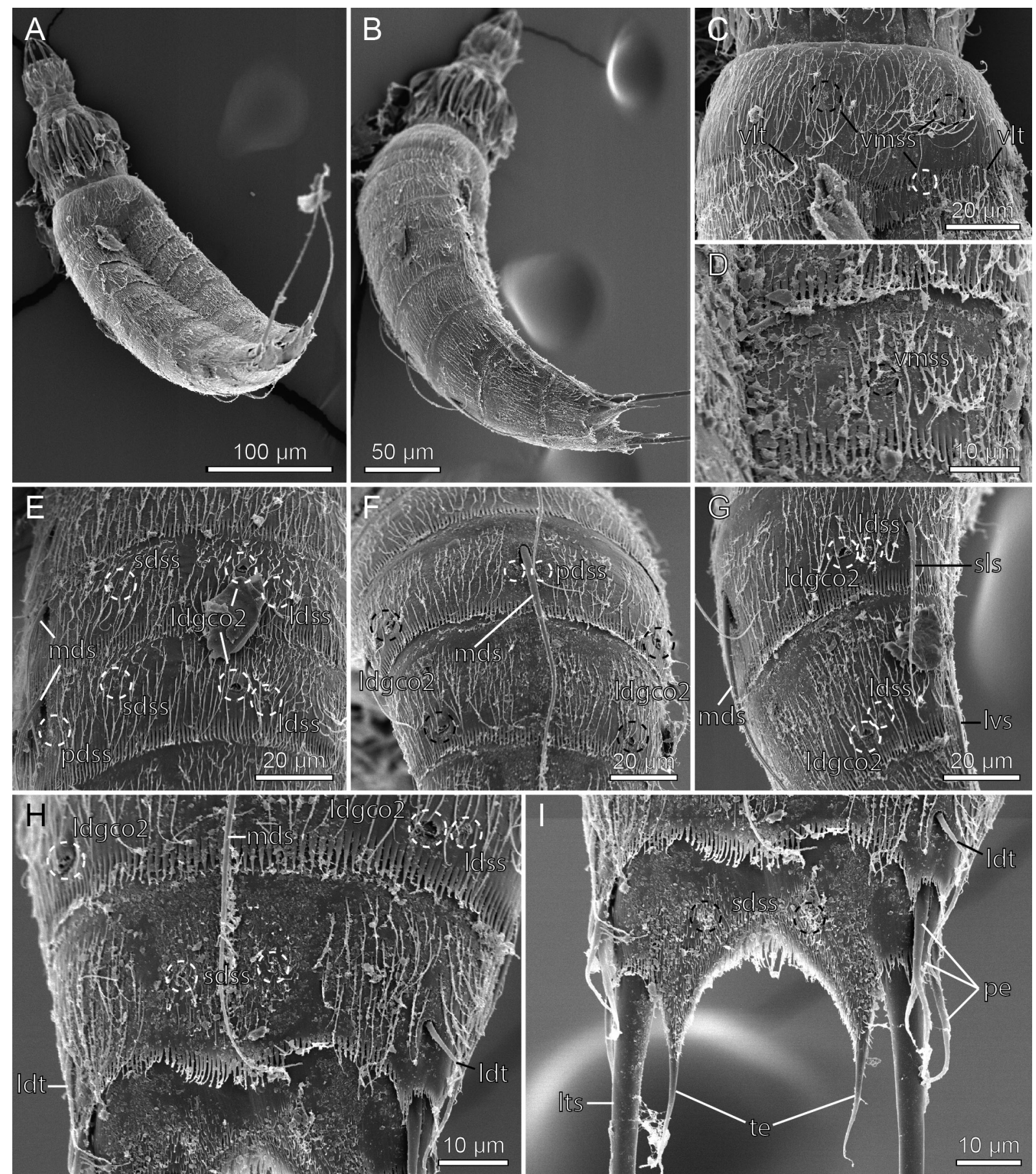

Fig. 27. Scanning electron micrographs showing overviews and details of Fissuroderes higginsi Neuhaus \& Blasche, 2006, §. A. Ventrolateral overview. B. Lateral overview. C. Segments 1 to 2, ventral view. D. Detail showing left sternal plate of segment 6 . E. Segments 4 to 6, laterodorsal view. F. Segments 8 to 9, dorsal view G. Segments 8 to 9, laterodorsal view. H. Segment 10, dorsal view. I. Segment 11, dorsal view. Abbreviations: ldgco2 = laterodorsal glandular cell outlet type 2; ldss = laterodorsal sensory spot; $1 \mathrm{dt}=$ laterodorsal tube; $1 \mathrm{ts}=$ lateral terminal spine; lvs = lateroventral spine; mds = middorsal spine; pdss = paradorsal sensory spot; $p$ e = penile spine; sdss = subdorsal sensory spot; $\mathrm{sls}=$ sublateral spine; te $=$ tergal extensions; vlt $=$ ventrolateral tube; vmss $=$ ventromedial sensory spot. 
Table 18. Summary of nature and location of sensory spots, glandular cell outlets, tubes and spines arranged by series in Fissuroderes higginsi. Abbreviations: LA = lateral accessory; LD = laterodorsal; $\mathrm{LV}=$ lateroventral; $\mathrm{MD}=$ middorsal; $\mathrm{ML}=$ midlateral; $\mathrm{PD}=$ paradorsal; $\mathrm{SD}=$ subdorsal; $\mathrm{SL}=$ sublateral; $\mathrm{VL}=$ ventrolateral; $\mathrm{VM}=$ ventromedial; ac $=$ acicular spine; gcol $/ 2=$ glandular cell outlet type $1 / 2$; lts = lateral terminal spine; $\mathrm{pe}=$ penile spines; $\mathrm{si}=$ sieve plate; $\mathrm{ss}=$ sensory spot; $\mathrm{tu}=$ tube; $\left({ }^{\Uparrow}\right)=$ male condition of sexually dimorphic characters; $*=$ marks characters differing in presence/absence from the original species description of Neuhaus \& Blasche $(2006) ;{ }^{(*)}=$ marks characters also present in the original species description of Neuhaus \& Blasche (2006), but in a slightly different position.

\begin{tabular}{|c|c|c|c|c|c|c|c|c|c|c|}
\hline \multicolumn{11}{|c|}{ Position } \\
\hline Segment & MD & PD & SD & LD & ML & SL & LA & $\mathbf{L V}$ & VL & VM \\
\hline 1 & gcol & & SS & & & & & gcol & & Ss \\
\hline 2 & gcol & & $\mathrm{tu}^{(*)}$ & SS & & & & & tu & SS \\
\hline 3 & gco1 & & no ss* & & & & & & & gcol \\
\hline 4 & ac & gcol & & & & & & & & gcol, ss \\
\hline 5 & $\mathrm{ac}$ & gcol & SS & gco2 & & & & tu & & gcol, ss \\
\hline 6 & $\mathrm{ac}$ & gcol, ss & SS & $\mathrm{gco} 2$ & & & & $\mathrm{ac}$ & & gcol, ss \\
\hline 7 & ac & gco 1, ss & SS & & & & & $\mathrm{ac}$ & & gcol, ss \\
\hline 8 & $\mathrm{ac}$ & gcol, ss & Ss & $\operatorname{gco} 2, \mathrm{ss}$ & & $\mathrm{ac}$ & & & & gcol, ss \\
\hline 9 & & gco 1, ss & SS & $\operatorname{gco} 2, \mathrm{ss}$ & & & si & ac & SS & gcol \\
\hline 10 & gcol, gcol & & SS & tu & & & & & SS & gco1 \\
\hline 11 & & & SS & & $x \operatorname{pe}\left(\partial^{\pi}\right)$ & & & lts & & \\
\hline
\end{tabular}

a key role in kinorhynch distribution. For instance, Grzelak \& Sørensen (2018 in press) showed that E. drogoni exists in depths ranging from 78 to $2128 \mathrm{~m}$, and Sørensen \& Landers (2018) described Sphenoderes aspidochelone Sørensen \& Landers, 2017 from a depth of 88 to $186 \mathrm{~m}$ in the northern Gulf of Mexico, but also reported the occurrence of the species at a depth of $1020 \mathrm{~m}$ in the southern Gulf of Mexico. An even more extreme example is Campyloderes cf. vanhöffeni, which has been recorded from intertidal habitats in the Faeroe Islands and down to $5118 \mathrm{~m}$ near the Canary Islands (Neuhaus \& Sørensen 2013). However, the latter should, as stressed by Neuhaus \& Sørensen (2013), be considered with some caution, since it might represent a cryptic species complex.

The findings of F. higginsi, E. cf. unispinosus and E. dubiosus sp. nov. from the northeast Pacific deepsea are way more puzzling. Fissuroderes higginsi is known from New Zealand (Neuhaus \& Blasche 2006) and E. unispinosus was described from the deep-sea plains near Sedlo Seamount in the Northeast Atlantic (Yamasaki et al. 2018b). Echinoderes dubiosus sp. nov. is here considered as a new species, but it shows a very close resemblance, and must putatively be very closely related, with E. bathyalis that was also described from Sedlo Seamount (Yamasaki et al. 2018a). These records suggest that deepsea echinoderids may show much larger distributional ranges than most of their congeners restricted to more shallow waters. It can obviously not be rejected that a molecular comparison between the northeast Pacific specimens, and specimens from New Zealand and the northeast Atlantic might reveal that they represent different cryptic species. In fact, it would be highly expected to find great molecular distances between the different populations due to their limited dispersal capabilities. But in any case, the morphological similarities would still indicate a very close relationship between on the one hand F. higginsi, E. unispinosus and E. bathyalis at their type localities and the 'lookalikes' were found at more than three northeast Pacific localities. Actually, Echinoderes dubiosus sp. nov. was found at all eight stations. These similarities between geographically very distant specimens could be explained in two ways. Either, the global deep-sea habitats are so homogeneous and similar in their selective pressure that genetic separation does not necessarily lead to morphological differences. Alternatively, the deep-sea species are able to spread over much greater distances, perhaps through deep-sea currents, which would enable the species to show larger distributional ranges than those usually known for more 
coastal species. It is currently impossible to determine which explanation is the most likely. But the results clearly indicate that distribution patterns for deep-sea kinorhynchs differ from those that we see for species at the continental shelfs. They also suggest that the deep-sea hosts a different and intriguing kinorhynch fauna, with much diversity and information remaining to be uncovered.

\section{Acknowledgements}

We are grateful to E.E. Easton, C. Armstrong, S. Bode, S. Bourgoin, M. Bublitz, E. Carroll, R. Carvalho, R. Coker, V. Cruz, E. Darrow, S. Dorado, J. Fields, L.E. Gilles, A.S. McInnes, R. Rowland, F. Stephenson, L. Rose and G.D.F. Wilson, who all helped at sea or in the laboratory during the sorting or processing of the material. We would furthermore like to thank Maria Herranz and Hiroshi Yamasaki for valuable discussions during the preparation of this manuscript, and the editorial teamof the European Journal of Taxonomy for exceptionally good processing of this contribution.

The samples were collected with support of the United States National Science Foundation under grant number 0727243 to DT.

\section{References}

Adrianov A.V. \& Higgins R.P. 1996. Pycnophyes parasanjuanensis, a new kinorhynch (Kinorhyncha: Homalorhagida: Pycnophyidae) from San Juan Island, Washington. Proceedings of the Biological Society of Washington 109: 236-247.

Adrianov A.V. \& Maiorova A.S. 2015. Pycnophyes abyssorum sp. n. (Kinorhyncha: Homalorhagida), the deepest kinorhynch described so far. Deep-Sea Research Part II 111: 49-59. https://doi.org/10.1016/j.dsr2.2014.08.009

Adrianov A.V. \& Maiorova A.S. 2016. Condyloderes kurilensis sp. n. (Kinorhyncha: Cyclorhagida) - a new deep water species from the abyssal plain near the Kuril-Kamchatka Trench. Russian Journal of Marine Biology 42: 11-19. https://doi.org/10.1134/s1063074016010028

Adrianov A.V. \& Maiorova A.S. in press. Meristoderes okhotensis sp. n. - the first deepwater representative of kinorhynchs in the Sea of Okhotsk (Kinorhyncha: Cyclorhagida). Deep-Sea Research Part II. https://doi.org/10.1016/j.dsr2.2017.10.011

Adrianov A.V. \& Malakhov V.V. 1999. Cephalorhyncha of the World Ocean. KMK Scientific Press, Moscow.

Bauer-Nebelsick M. 1996. Antygomonas oreas sp. n., a new deep sea kinorhynch from the Pacific Ocean. Annalen des Naturhistorischen Museums in Wien, Serie B 98B: 5-22.

DalZotto M. \& TodaroA. 2016. Kinorhyncha from Italy, a revision of the current checklist and an account of the recent investigations. Zoologischer Anzeiger 265: 90-107. https://doi.org/10.1016/j.jcz.2016.01.004

Dal Zotto M., Di Domenico M., Garraffoni A. \& Sørensen M.V. 2013. Franciscideres gen. nov. a new, highly aberrant kinorhynch genus from Brazil, with an analysis of its phylogenetic position. Systematics and Biodiversity 11: 303-321. https://doi.org/10.1080/14772000.2013.819045

Danovaro R., Gambi C. \& Della Croce N. 2002. Meiofauna hotspot in the Atacama Trench, eastern South Pacific Ocean. Deep-Sea Research Part I 49: 843-857. https://doi.org/10.1016/s0967-0637(01)00084-x

Grzelak K. \& Sørensen M.V. 2018. New species of Echinoderes (Kinorhyncha: Cyclorhagida) from Spitsbergen, with additional information about known Arctic species. Marine Biology Research 14: 113-147. https://doi.org/10.1080/17451000.2017.1367096 [published online in 2017]. 
Grzelak K. \& Sørensen M.V. in press. Diversity and distribution of Arctic Echinoderes species (Kinorhyncha: Cyclorhagida), with the description of one new species and a redescription of E. arlis, Higgins 1966. Marine Biodiversity. https://doi.org/10.1007/s12526-018-0889-2

Herranz M. \& Leander B. 2016. Redescription of Echinoderes ohtsukai Yamasaki and Kajihara, 2012 and E. kozloffi Higgins, 1977 from the Northwest Pacific coast, including the first report of a potential invasive species of kinorhynch. Zoologischer Anzeiger 265: 108-126. https://doi.org/10.1016/j.jcz.2016.02.004

Herranz M. \& Pardos F. 2013. Fissuroderes sorenseni sp. nov. and Meristoderes boylei sp. nov.: First Atlantic recording of two rare kinorhynch genera, with new identification keys. Zoologischer Anzeiger 253: 93-111. https://doi.org/10.1016/j.jcz.2013.09.005

Herranz M., Sánchez N., Pardos F. \& Higgins R.P. 2014. New Kinorhyncha from Florida coastal waters. Helgoland Marine Research 68: 59-87. https://doi.org/10.1007/s10152-013-0369-9

Herranz M., Yangel E. \& Leander B. 2018. Echinoderes hakaiensis sp. nov.: a new mud dragon (Kinorhyncha, Echinoderidae) from the northeastern Pacific Ocean with the redescription of Echinoderes pennaki Higgins, 1960. Marine Biodiversity 48: 303-325. https://doi.org/10.1007/s12526-017-0726-z

Higgins R.P. 1960. A new species of Echinoderes (Kinorhyncha) from Puget Sound. Transactions of the American Microscopical Society 79: 85-91.

Higgins R.P. 1961. Three new homalorhage kinorhynchs from the San Juan Archipelago, Washington. Journal of the Elisha Mitchell Scientific Society 77: 81-88.

Higgins R.P. 1964. Three new kinorhynchs from the North Carolina coast. Bulletin of Marine Science of the Gulf and Caribbean 14: 479-493.

Higgins R.P. 1966. Echinoderes arlis, a new kinorhynch from the Arctic Ocean. Pacific Science 20: $518-520$.

Higgins R.P. 1967. The Kinorhyncha of New-Caledonia. In: Expédition française sur les Récifs coralliens de la Nouvelle-Calédonie 2: 75-90. Fondation Singer-Polignac, Paris.

Higgins R.P. 1977. Redescription of Echinoderes dujardinii (Kinorhyncha) with descriptions of closely related species. Smithsonian Contributions to Zoology 248: 1-26.

Higgins R.P. 1986. A new species of Echinoderes (Kinorhyncha: Cyclorhagida) from a coarse-sand California beach. Transactions of the American Microscopical Society 105: 266-273.

Higgins R.P. \& Kristensen R.M. 1988. Kinorhyncha from Disko Island, West Greenland. Smithsonian Contributions to Zoology 458: 1-56.

Huys R. \& Coomans A. 1989. Echinoderes higginsi sp. n. (Kinorhyncha, Cyclorhagida) from the southern North Sea with a key to the genus Echinoderes Claparède. Zoologica Scripta 18: 211-221.

Landers S.C. \& Sørensen M.V. 2016. Two new species of Echinoderes (Kinorhyncha, Cyclorhagida), E. romanoi sp. n. and E. joyceae sp. n., from the Gulf of Mexico. ZooKeys 594: 51-71. https://doi.org/10.3897/zookeys.594.8623

Landers S.C. \& Sørensen M.V. in press. Echinoderes sylviae n. sp. (Kinorhyncha, Cyclorhagida), from the Gulf of Mexico, with comparative notes on a similar species Echinoderes spinifurca. Bulletin of Marine Science. https://doi.org/10.5343/bms.2017.1167

Landers S.C., Sørensen M.V., Beaton K.R., Jones C.M., Miller J.M. \& Stewart P.M. 2018. Kinorhynch assemblages in the Gulf of Mexico continental shelf collected during a two-year survey. Journal of Experimental Marine Biology and Ecology 502: 81-90. https://doi.org/10.1016/j.jembe.2017.05.013 
Lou T.-H. 1934. Sur la présence d'un nouveau kinorhynque a Tchefou: Echinoderes tchefouensis sp. nov. Contributions from the Institute of Zoology, National Academy of Peiping 1: 1-9. [In Chinese with French translation.]

Neuhaus B. \& Blasche T. 2006. Fissuroderes, a new genus of Kinorhyncha (Cyclorhagida) from the deep sea and continental shelf of New Zealand and from the continental shelf of Costa Rica. Zoologischer Anzeiger 245: 19-52. https://doi.org/10.1016/j.jcz.2006.03.003

Neuhaus B. \& Kegel A. 2015. Redescription of Cateria gerlachi (Kinorhyncha, Cyclorhagida) from Sri Lanka and of C. styx from Brazil, with notes on C. gerlachi from India and C. styx from Chile, and the ground pattern of the genus. Zootaxa 3965: 1-77. https://doi.org/10.11646/zootaxa.3965.1.1

Neuhaus B. \& Sørensen M.V. 2013. Populations of Campyloderes sp. (Kinorhyncha, Cyclorhagida): One global species with significant morphological variation? Zoologischer Anzeiger 252: 48-75. https://doi.org/10.1016/j.jcz.2012.03.002

Neuhaus B., Pardos F., Sørensen M.V. \& Higgins R.P. 2014. New species of Centroderes (Kinorhyncha: Cyclorhagida) from the Northwest Atlantic Ocean, life cycle, and ground pattern of the genus. Zootaxa 3901: 1-69. https://doi.org/10.11646/zootaxa.3901.1.1

Neves R.C., Sørensen M.V. \& Herranz M. 2016. First account on kinorhynchs from Portugal, with the description of two new species: Echinoderes lusitanicus sp. nov. and E. reicherti sp. nov. Marine Biology Research 12: 455-470. https://doi.org/10.1080/17451000.2016.1154973

Neves R.C., Kristensen R.M., Rohal M., Thistle D. \& Sørensen M.V. in press. First report of Loricifera from the North East Pacific Region, with description of two new species. Marine Biodiversity. https://doi.org/10.1007/s12526-018-0898-1

Pardos F., Herranz M. \& Sánchez N. 2016a. Two sides of a coin: the phylum Kinorhyncha in Panama. I) Caribbean Panama. Zoologischer Anzeiger 265: 3-25. https://doi.org/10.1016/j.jcz.2016.06.005

Pardos F., Herranz M. \& Sánchez N. 2016b. Two sides of a coin: the phylum Kinorhyncha in Panama. II) Pacific Panama. Zoologischer Anzeiger 265: 3-25. https://doi.org/10.1016/j.jcz.2016.06.006

Rohal M., Thistle D. \& Easton E.E. 2014. Meiofaunal abundances and faunal similarity on the continental rise off the coast of California. Deep-Sea Research I 93: 131-144.

https://doi.org/10.1016/j.dsr.2014.07.004

Sánchez N. \& Yamasaki H. 2016. Two new Pycnophyidae species (Kinorhyncha: Allomalorhagida) from Japan lacking ventral tubes in males. Zoologischer Anzeiger 265: 80-89. https://doi.org/10.1016/j.jcz.2016.04.001

Sánchez N., Herranz M., Benito J. \& Pardos F. 2012. Kinorhyncha from the Iberian Peninsula: new data from the first intensive sampling campaigns. Zootaxa 3402: 24-44.

Sánchez N., Rho H.S., Min W.G., Kim D. \& Sørensen M.V. 2013. Four new species of Pycnophyes (Kinorhyncha: Homalorhagida) from Korea and the East China Sea. Scientia Marina 77: 353-380.

Sánchez N., Pardos F. \& Sørensen M.V. 2014a. A new kinorhynch genus, Mixtophyes (Kinorhyncha: Homalorhagida), from the Guinea Basin deep-sea, with new data on the family Neocentrophyidae. Helgoland Marine Research 68: 221-239. https://doi.org/10.1007/s10152-014-0383-6

Sánchez N., Pardos F. \& Sørensen M.V. 2014b. Deep-sea Kinorhyncha: two new species from the Guinea Basin, with evaluation of an unusual male feature. Organisms Diversity and Evolution 14: 349-361. https://doi.org/10.1007/s13127-014-0182-6 
Sørensen M.V. 2008. A new kinorhynch genus from the Antarctic deep-sea and a new species of Cephalorhyncha from Hawaii (Kinorhyncha: Cyclorhagida: Echinoderidae). Organisms Diversity and Evolution 8: 233-246. https://doi.org/10.1016/j.ode.2007.11.003

Sørensen M.V. 2014. First account of echinoderid kinorhynchs from Brazil, with the description of three new species. Marine Biodiversity 44: 251-274. https://doi.org/10.1007/s12526-013-0181-4

Sørensen M.V. 2018. Redescription of Echinoderes levanderi Karling, 1954 (Kinorhyncha: Cyclorhagida) - a kinorhynch tolerant to very low salinities. European Journal of Taxonomy 436: 1-17. https://doi.org/10.5852/ejt.2018.436

Sørensen M.V. \& Landers S.C. 2014. Two new species of Echinoderes (Kinorhyncha: Cyclorhagida) from the Gulf of Mexico. Frontiers in Marine Science 1 (8): 1-18. https://doi.org/10.3389/fmars.2014.00008

Sørensen M.V. \& Landers S.C. 2017. Description of a new species, Paracentrophyes sanchezae n. sp. (Kinorhyncha: Allomalorhagida) from the Gulf of Mexico, with differential notes on one additional, yet undescribed species of the genus. Zootaxa 4242: 61-76. https://doi.org/10.11646/zootaxa.4242.1.3

Sørensen M.V. \& Landers S.C. 2018. New species of Semnoderidae (Kinorhyncha: Cyclorhagida: Kentrorhagata) from the Gulf of Mexico. Marine Biodiversity 48: 327-355. https://doi.org/10.1007/s12526-017-0728-x

Sørensen M.V., Heiner I. \& Ziemer O. 2005. A new species of Echinoderes from Florida (Kinorhyncha: Cyclorhagida). Proceedings of the Biological Society of Washington 118: 499-508.

Sørensen M.V., Rho HS., Min W., Kim D. \& Chang C.Y. 2012. An exploration of Echinoderes (Kinorhyncha: Cyclorhagida) in Korean and neighboring waters, with the description of four new species and a redescription of E. tchefouensis Lou, 1934. Zootaxa 3368: 161-196.

Sørensen M.V., Dal Zotto M., Rho H.S., Herranz M., Sánchez N., Pardos F. \& Yamasaki H. 2015. Phylogeny of Kinorhyncha based on morphology and two molecular loci. PLoS One 10(7): e0133440. https://doi.org/10.1371/journal.pone.0133440

Sørensen M.V., Herranz M. \& Landers S.C. 2016a. A new species of Echinoderes (Kinorhyncha: Cyclorhagida) from the Gulf of Mexico, with a redescription of Echinoderes bookhouti Higgins, 1964. Zoologischer Anzeiger 265: 48-68. https://doi.org/10.1016/j.jcz.2016.04.004

Sørensen M.V., Gąsiorowski L., Randsø P.V., Sánchez N. \& Neves R.C. 2016b. First report of kinorhynchs from Singapore, with the description of three new species. Raffles Bulletin of Zoology 64: 3-27.

Thormar J. \& Sørensen M.V. 2010. Two new species of Echinoderes (Kinorhyncha: Cyclorhagida) from the Solomon Islands. Meiofauna Marina 18: 67-96.

Tietjen J.H., Deming J.W., Rowe G.T., Macko S. \& Wilke R.J. 1989. Meiobenthos of the Hatteras Abyssal Plain and Puerto Rico Trench: abundance, biomass, and associations with bacteria and particulate fluxes. Deep-Sea Research Part A 36: 1567-1577. https://doi.org/10.1016/0198-0149(89)90058-7

Yamasaki H. 2016a. Ryuguderes iejimaensis, a new genus and species of Campyloderidae (Xenosomata: Cyclorhagida: Kinorhyncha) from a submarine cave in the Ryukyu Islands, Japan. Zoologischer Anzeiger 265: 69-79. https://doi.org/10.1016/j.jcz.2016.02.003

Yamasaki H. 2016b. Two new Echinoderes species (Echinoderidae, Cyclorhagida, Kinorhyncha) from Nha Trang, Vietnam. Zoological Studies 55 (32): 1-21. https://doi.org/10.6620/ZS.2016.55-32

Yamasaki H., Neuhaus B. \& George K.H. 2018a. Echinoderidae (Cyclorhagida: Kinorhyncha) from two seamounts and the adjacent deep-sea floor in the Northeast Atlantic Ocean, including descriptions of three new species. Cahiers de Biologie Marine 59: 79-106. 
YamasakiH.,NeuhausB.\& GeorgeK.H.2018b. New species of Echinoderes (Kinorhyncha: Cyclorhagida) from Mediterranean Seamounts and from the deep-sea floor in the Northeast Atlantic Ocean, including notes on two undescribed species. Zootaxa 4378: 541-566. https://doi.org/10.11646/zootaxa.4387.3.8

Yamasaki H., Grzelak K., Sørensen M.V., Neuhaus B. \& George K.H. 2018c. Echinoderes pterus sp. n. showing a geographically and bathymetrically wide distribution pattern on seamounts and on the deepsea floor in the Arctic Ocean, Atlantic Ocean, and the Mediterranean Sea (Kinorhyncha, Cyclorhagida). ZooKeys 771: 15-40. https://doi.org/10.3897/zookeys.771.25534

Manuscript received: 27 March 2018

Manuscript accepted: 11 June 2018

Published on: 17 August 2018

Topic editor: Rudy Jocqué

Desk editor: Kristiaan Hoedemakers

Printed versions of all papers are also deposited in the libraries of the institutes that are members of the EJT consortium: Muséum national d'Histoire naturelle, Paris, France; Botanic Garden Meise, Belgium; Royal Museum for Central Africa, Tervuren, Belgium; Natural History Museum, London, United Kingdom; Royal Belgian Institute of Natural Sciences, Brussels, Belgium; Natural History Museum of Denmark, Copenhagen, Denmark; Naturalis Biodiversity Center, Leiden, the Netherlands; Museo Nacional de Ciencias Naturales-CSIC, Madrid, Spain; Real Jardín Botánico de Madrid CSIC, Spain; Zoological Research Museum Alexander Koenig, Bonn, Germany. 